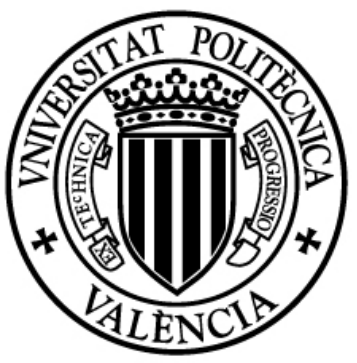

\title{
Molecular aspects of dormancy in peach (Prunus persica [L.] Batsch)
}

TESIS DOCTORAL

Presentada por

Carmen Alice Leida

Dirigida por

Dr. Gabino Ríos García

Dra. María Luisa Badenes Catalá

Valencia, Febrero 2012 





\section{AGRADECIMIENTOS}

En estos cuatros años en los que he estado trabajando, he conocido a mucha gente que me ha ayudado en distintas formas para la realización de esta tesis y por eso he pensado en agradecerlos.

En primer lugar quería dar las gracias a mis directores por la dedicación que me han prestado. A Gerardo y Marisa por darme la oportunidad de trabajar en el IVIA y de desarrollar esta tesis. A Gabino por haber estado ahí en todo momento, para enseñar y contestar a mis preguntas, sin su apoyo no habría podido llegar hasta aquí.

Me gustaría agradecer a las personas que han colaborado conmigo en las distintas tareas realizadas: a Gracia Martí y al Dr. Manuel Agustí por las medidas de la salida de latencia del primer trabajo, al Dr. Javier Teról y a la Dra. Ana Conesa por su ayuda en la parte de limpieza de secuencias, anotación y elaboración de los microarrays, a José Francisco Romeu y al Dr. Jesús García Brunton por su contribución en la parte de los modelos climáticos, al Dr. Vicente Arbona y al Dr. Aurelio Gómez-Cadena por la ayuda en las medidas de ABA y de compuestos fenólicos en las semillas. También me gustaría agradecer a Ana por su ayuda con la siembra in vitro.

No puedo olvidarme del grupo de frutales; compañeros y amigos que han hestado a mi lado, que han solucionado alguna duda o simplemente han compartido los momentos duros y también las risas. Muchas gracias a Carlos, José Miguel, Elena, Mar, Mati, Ana, Anna Délia, Laura M y Laura R. También a los que siguen con su doctorado como Juanvi y Blasco o con sus practicas como Jitka; quería darles animo porque al final las cosas salen!

Gracias a José, Pepe y Enzo por el cuidado de las plantas en el campo y en el invernadero, y por haberme enseñado a injertar.

$Y$ por último, aunque no por esto menos importante, muchas gracias a mi familia por el apoyo. A mis padres, mis hermanos y a mis tíos Elisabetta y Valeriano que siempre me han empujado. $Y$ a Christian, por creer en mí y hacer que entre los dos todo sea mucho más llevadero. 



\section{ABSTRACT}

Dormancy is one of the most important adaptive mechanisms developed by perennial plants, in order to survive the low temperatures of autumn and winter in temperate climates. The study of the genes regulated during dormancy release is crucial to understand the process, with the final objective of the development of new varieties with a better adaptation to certain environments; and this is particularly important considering the increasing economical weight of fruit crops in low and medium chilling regions as the Mediterranean area. We focused on the molecular and physiological mechanisms underlying the maintenance and release of seasonal dormancy in peach. In order to achieve this we first used suppression subtractive hybridization (SSH) to identify genes expressed in dormant and dormancy-released buds in two cultivars with different chilling requirements, 'Zincal-5' and 'Springlady', and subsequently validated their differential expression utilizing a peach cDNA microarray platform containing transcripts enriched in flower buds. Additionally, we carried out a genome-wide search of peach genes related to dormancy release by hybridizing the previous cDNA microarray with mRNA samples from 10 cultivars showing different dormancy behaviour, followed by an expression correlation analysis.

Among the most relevant genes identified in these two first works, we found the DORMANCY ASSOCIATED MADS-box genes DAM4, DAM5 and DAM6, described independently by other groups working in peach and other species. The central role of DAM genes in dormancy regulation has also been confirmed by additional functional approaches as the analysis of the non-dormant evg mutant, QTL analysis, and transgenic approaches.

In our second work we focused on the molecular mechanisms of DAM6 down-regulation concomitant with dormancy release in flower buds. A ChIP analysis of DAM6 promoter and structural gene revealed chromatin modification events similar to those observed in vernalization of Arabidopsis and cereals. We showed that DAM6 is transcriptionally active in dormant buds collected in October, when a short chromatin region around its ATG was trimethylated in histone $\mathrm{H} 3$ at $\mathrm{K} 4(\mathrm{H} 3 \mathrm{~K} 4)$ and acetylated at the N-terminal tail of H3. Concomitantly with DAM6 repression, H3K4 became demethylated and $\mathrm{H} 3$ deacetylated. Later H3K27 was found trimethylated along a genomic region larger than $4 \mathrm{~kb}$, including promoter, coding sequence and intron. Due to their relevance in dormancy regulation, DAM genes could be used as expression markers to assess the dormancy stage of an individual plant and to evaluate the chilling requirements of new cultivars. In fact, we have shown in this work that the expression pattern of 
DAM5, together with other transcripts (BD396, DB247, SB280 and PpB63), correlates well with chilling requirements values of five different varieties ('Big Top', 'Catherina', 'Fergold', 'Maruja' and 'Springlady') measured following Utah and Dynamic models.

Some of the genes identified in transcriptomic experiments using flower buds, as DAM1, $D A M 5$ and DAM6, were also regulated during the cold stratification of peach seeds, suggesting the presence of common regulatory pathways in the dormancy process of buds and seeds. These similarities between bud and seed dormancy have possible important implications in the evaluation of bud chilling requirements of early and late flowering genotypes directly at seed level greatly reducing the time needed for evaluating plant material in breeding programs.

Among others, a significant number of genes identified in this work were homologous to ABA and drought related genes from other species. ABA, in fact, has been proposed to promote and maintain bud dormancy although few molecular data support this prediction. Our data contribute to highlight a prominent role of $\mathrm{ABA}$ in dormancy processes and also uncover elements of the $\mathrm{ABA}$ and drought regulatory response in peach, as an ABA-INSENSITIVE5 (ABI5) binding protein (AFP)-like, a dehydration-responsive element (DRE)-binding protein (DREB2C)-like, a calciumbinding annexin, and several genes regulated by stress signalling pathways. 


\section{RESUMEN}

La latencia es uno de los mecanismos adaptativos más importantes desarrollados por las plantas perennes para sobrevivir a las bajas temperaturas estacionales en climas templados. El estudio de los genes regulados durante la salida de la latencia es crucial para entender este proceso y poder obtener nuevas variedades con una adecuada adaptación climática a la zona de cultivo. Esto es particularmente relevante en el área mediterránea, donde el peso económico del cultivo de frutales con bajos y medios requerimentos de frío se esta incrementando notablemente. En esta tesis se han estudiado aspectos moleculares y fisiológicos que rodean al mantenimiento y salida de latencia en melocotonero. Para ello, se ha utilizado la técnica de hibridación substractiva supresiva, que ha permitido identificar genes expresados en yemas latentes y no latentes en dos variedades con diferentes requerimientos en horas frío, 'Zincal 5' y 'Springlady'. Posteriormente, se ha validado su expresión diferencial mediante una micromatriz de cDNA que contenía transcritos enriquecidos en yema floral. Además, mediante hibridación de la micromatriz anterior con muestras de RNA procedentes de 10 cultivares que diferían en su comportamiento respecto a la latencia, se han identificado genes cuya expresión correlacionaba con el estado de latencia del material ensayado.

Dentro de los genes más relevantes identificados en estos dos trabajos se encuentran los genes DORMANCY ASSOCIATED MADS-box (DAM) DAM4, DAM5 and DAM6, previamente descritos de forma independiente por otros autores que trabajan en melocotonero y otras especies leñosas $\mathrm{Su}$ papel en la latencia se ha confirmado por medio de pruebas funcionales como el análisis del mutante no latente evg, el mapeo de QTL, y mediante el uso de plantas transgénicas.

En un segundo trabajo se ha estudiadoel mecanismo molecular de la represión de DAM6 durante la salida de latencia en yema floral. El análisis de inmunoprecipitación de cromatina en la zona del promotor y gen estructural de DAM6 reveló modificaciones similares a las observadas en la vernalización de Arabidopsis y cereales. Los resultados han demostrado que DAM6 se transcribe en yema latente recolectada en octubre, cuando una pequeña región de cromatina alrededor del ATG se encuentra trimetilada en la lisina 4 (K4) de la histona H3 y acetilada en la cola N-terminal de H3. En paralelo a la represión de DAM6, H3K4 se demetila y H3 se deacetila. Posteriormente, H3K27 se encuentra trimetilada a lo largo de una región genómica mayor de 4kb, que incluye promotor, secuencia codificante e intrón.

Debido a su relevancia en la regulación de la latencia, los genes DAM podrían ser utilizados como marcadores de expresión para evaluar el estado de latencia de una planta individual, y para 
evaluar los requerimentos en frío de nuevas variedades. De hecho en este trabajo se ha demostrado que la expresión de DAM5, junto con otros transcritos (BD396, DB247, SB280 y PpB63), se correlaciona con las estimaciones de requerimentos de frío en cinco cultivares diferentes ('Big Top', 'Catherina', 'Fergold', 'Maruja' y 'Springlady'), medidos mediante los modelos Utah y Dynamic.

Algunos de los genes identificados en los experimentos de transcriptómica con yema floral, como DAM1, DAM5 y DAM6, son regulados durante la estratificación en frío de las semillas de melocotonero, sugiriendo la existencia de rutas de regulación comunes en los procesos de latencia de semilla y yema. Estas similitudes entre la latencia de yema y semilla podrían justificar el empleo de la semilla para la estimación de los requerimentos de frío de diferentes genotipos, reduciendo considerablemente el tiempo necesario para la evaluación del material vegetal en los programas de mejora.

Un numero significativo de genes identificados en este trabajo muestran homología a genes relacionados con el ABA y estrés hídrico en otras especies. El ABA, es considerado uno de los principales inductores de la latencia en la yema, sin embargo pocos datos moleculares apoyan esta idea. Nuestros datos contribuyen a resaltar el importante papel del ABA en el proceso de latencia y también a desentrañar los elementos de la respuesta reguladora del ABA y el estrés hídrico en melocotonero. Entre ellos se encuentran una proteína similar a ABA-INSENSITIVE5 (ABI5) BINDING PROTEIN (AFP), una proteína de regulación de la respuesta al estrés hídrico similar a DREB2C, y una anexina. 


\section{RESUM}

La latència és un dels mecanismes adaptatius més importants desenrotllats per les plantes perennes per a sobreviure a les baixes temperatures estacionals en climes temperats. L'estudi dels gens regulats durant l'eixida de la latència és crucial per a entendre este procés i poder obtindre noves varietats amb una adequada adaptació climàtica a la zona de cultiu. Açò és particularment rellevant en l'àrea mediterrània, on el pes econòmic del cultiu de fruiters amb baixos i mitjans requeriments de fred s'està incrementant notablement. En esta tesi s'han estudiat aspectes moleculars i fisiològics que rodegen al manteniment i eixida de latència en bresquillera. Per a això, s'ha utilitzat la tècnica d'hibridació substractiva supressiva, que ha permés identificar gens expressats en gemmes latents i no latents en dos varietats amb diferents requeriments en hores fred, 'Zincal 5' i 'Springlady'. Posteriorment, s'ha validat la seua expressió diferencial per mitjà d'una micromatriu de cDNA que contenia transcrits enriquits en gemma floral. A més, per mitjà d'hibridació de la micromatriu anterior amb mostres de RNA procedents de 10 cultivars que diferien en el seu comportament respecte a la latència, s'han identificat gens l'expressió dels quals correlacionava amb l'estat de latència del material assajat.

Dins dels gens més rellevants identificats en estos dos treballs es troben els gens DORMANCY ASSOCIATED MADS-box (DAM) DAM4, DAM5 i DAM6, prèviament descrits de forma independent per altres autors que treballen en bresquillera i altres espècies llenyoses El seu paper en la latència s'ha confirmat per mitjà de proves funcionals com l'anàlisi del mutant no latent evg, el mapeig de QTL, i per mitjà de l'ús de plantes transgèniques.

En un segon treball s'ha estudiat el mecanisme molecular de la repressió de DAM6 durant l'eixida de latència en gemmes florals. L'anàlisi d'inmunoprecipitació de cromatina en la zona del promotor i gen estructural de DAM6 va revelar modificacions semblants a les observades en la vernalització d'Arabidopsis i cereals. Els resultats han demostrat que DAM6 es transcriu en gemma latent recol.lectada en octubre, quan una xicoteta regió de cromatina al voltant de l' ATG es troba trimetilada en la lisina 4 (K4) de la histona H3 i acetilada en la cua N-terminal d' H3. En paral.lel a la represió de DAM6, H3K4 es demetila i H3 es deacetila. Posteriorment, H3K27 es troba trimetilada en una regió genómica major de $4 \mathrm{~kb}$, que inclou promotor, seqüència codificant i intró.

Alguns dels gens identificats en els experiments de transcriptòmica amb gemma floral, com DAM1, DAM5 i DAM6, són regulats durant l'estratificació en fred de les llavors de bresquillera, suggerint l'existència de rutes de regulació comuna en els processos de latència de llavor i gemma. 
Estes similituds entre la latència de gemma i llavor podrien justificar l'ús de la llavor per a l'estimació dels requeriments de fred de diferents genotips, reduint considerablement el temps necessari per a l'avaluació del material vegetal en els programes de millora.

Un nombre significatiu de gens identificats en este treball mostren homologia a gens relacionats amb l'ABA i estrés hídric en altres espècies. L'ABA, és considerat un dels principals inductors de la latència en la gemma, no obstant això poques dades moleculars recolzen esta idea. Les nostres dades contribuïxen a ressaltar l'important paper de l'ABA en el procés de latència i també a desentranyar els elements de la resposta reguladora de l'ABA i l'estrés hídric en bresquillera. Entre ells es troben una proteïna semblant a ABA-INSENSITIVE5 (ABI5) BINDING PROTEUET (AFP), una proteïna de regulació de la resposta a l'estrés hídric semblant a DREB2C, i una anexina. 


\section{INDEX}

ABSTRACT

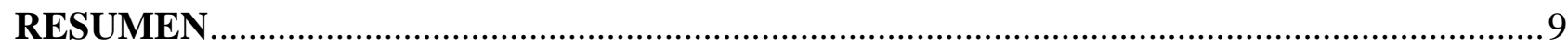

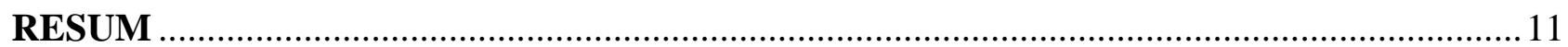

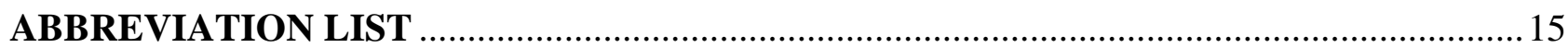

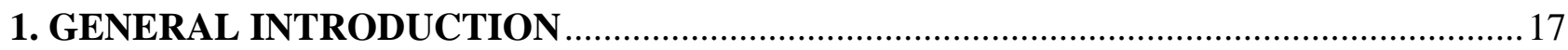

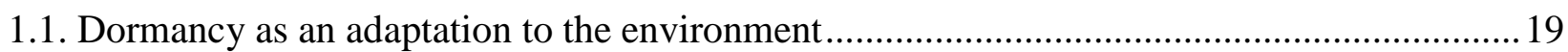

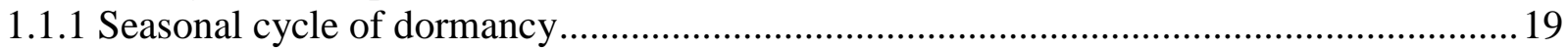

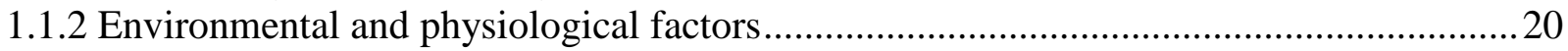

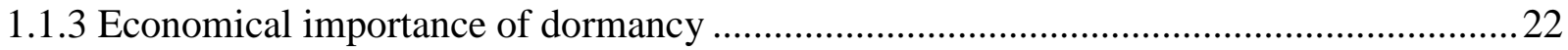

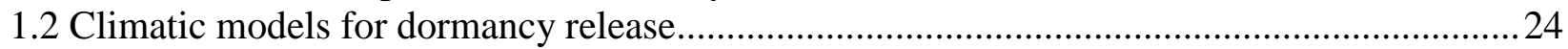

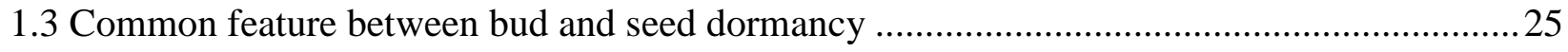

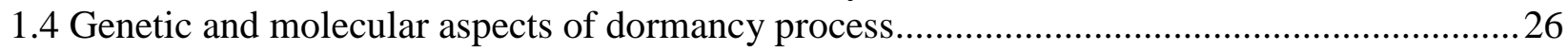

1.4.1 Genetic studies and mapping of dormancy associated loci............................................26

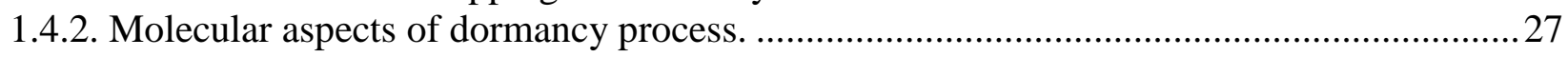

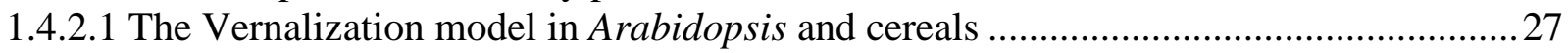

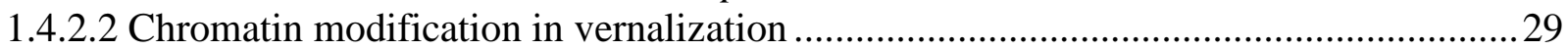

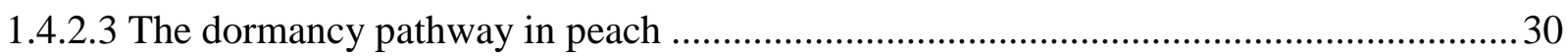

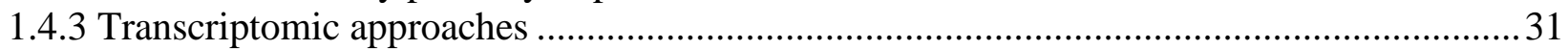

1.4.3.1 Genes involved in membrane alterations: cell wall modification and cell expansion ...33

1.4.3.2 Genes involved in sugar metabolism and carbohydrate catabolism ............................ 33

1.4.3.3 Proteins related to stress or protection responses and detoxification processes .............34

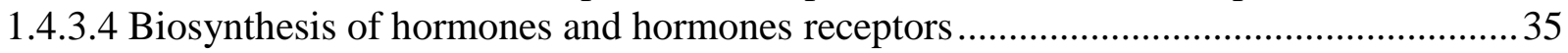

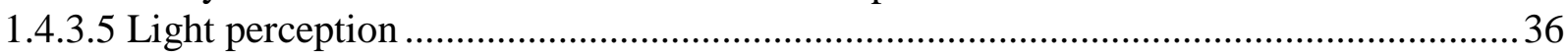

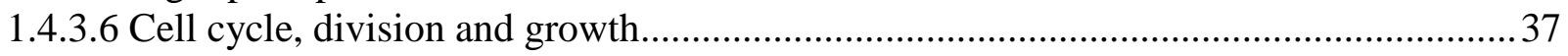

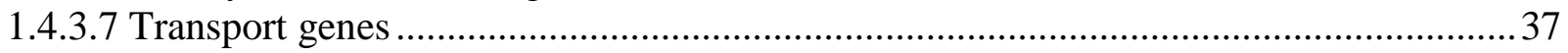

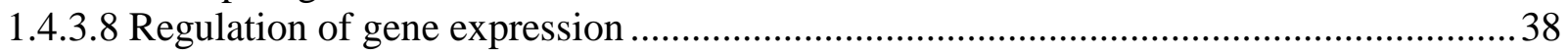

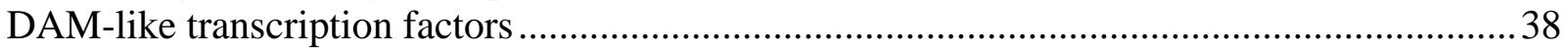

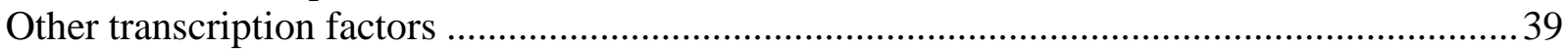

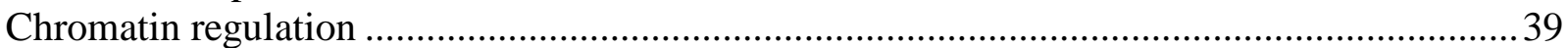

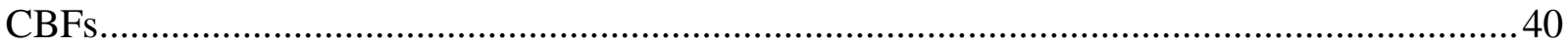

1.5 Transgenic approaches towards the regulation of bud dormancy ...................................... 40

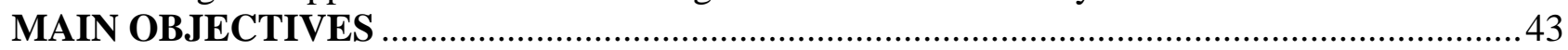

2. Identification of genes associated with bud dormancy release in Prunus persica by

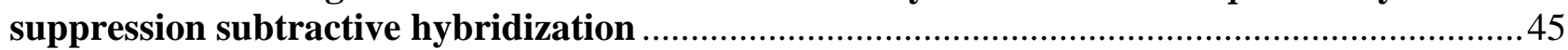

3. Histone modifications and expression of DAM6 gene in peach are modulated during bud dormancy release in a cultivar-dependent manner .............................................................69

4. Gene expression analysis of chilling requirements for flower bud break in peach ..............95

5. Chilling-dependent release of seed and bud dormancy in peach associates to common

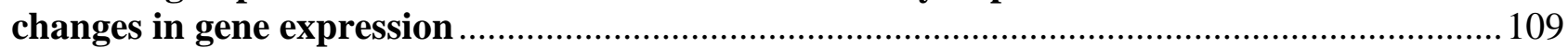

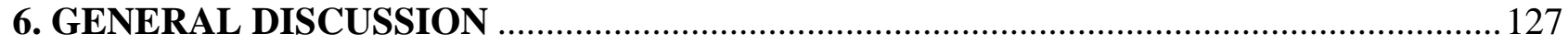

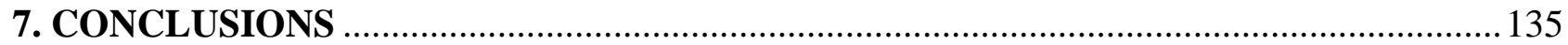

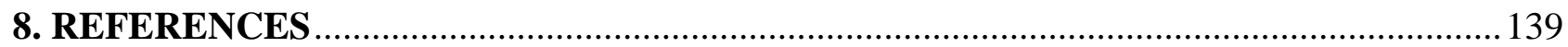





\section{ABBREVIATION LIST}
ABA Abscisic Acid
BD Blooming Date
BLASTN/P Basic Local Alignment Tool Nucleotide/Protein
ChIP Chromatin Immunoprecipitation
CR Chilling Requirement
CU Chilling Units
DAM Dormancy Associated MADS-box
DR Dormant bud cDNA library
EST Expressed Sequence Tag
evg evergrowing
GA Gibberellins, Gibberellic Acid
H3K27 Histone H3 Lysine-27
H3K4 Histone H3 Lysine-4
HC Hydrogen Cyanamide
HR Heat Requirement
IAA Indoleacetic Acid
JA Jasmonic Acid
LD Long Day
LG Linkage Group
MADS MCM1/AGAMOUS/DEFICIENS/SERUM RESPONSE FACTOR
MTB Mean Time to Budbreak
QTL Quantitative Trait Loci
RD Dormancy release bud cDNA library
SCAR Sequences Characterized Amplified Region
SD Short Day
SSH Subtractive Suppressive Hybridization
SSR Simple Sequence Repeated
SZ 'Springlady' cDNA library
ZS 'Zincal 5' cDNA library 

1. GENERAL INTRODUCTION 



\subsection{Dormancy as an adaptation to the environment}

Perennial plants are able to survive under unfavourable climatic conditions through a seasonal stage of latent growth named dormancy. The study of dormancy has been a matter of interest for scientists covering almost a century of work, including genetics, physiology, biochemistry, agronomy, and molecular biology. Lang et al. (1987) defined dormancy for the first time as the "temporary suspension of visible growth of any plant structure containing a meristem". He further distinguished between paradormancy, when growth is inhibited by distal organs, endodormancy when growth is inhibited by internal signals, and ecodormancy, which is provoked by environmental conditions. Despite some limitations in this definition, Lang's description had been widely utilized by the scientific community for years. A more recent definition of dormancy has been proposed by Rohde \& Balherao (2007), as "the inability to resume growth from meristems (and other organs and cells) under favourable conditions". Dormancy is a physiological mechanism that involves different metabolic pathways: light perception, hormones, cell cycle and abiotic stress resistance.

Dormancy is the result of plant adaptation to the environment and the variation in intensity is due to the different pressure exercised at different latitudes. Among the same species, this climatic variations generated different genotypes with a distinct dormancy intensity (Heide et al., 1977). In cases where this pressure was released, some annual plants at the tropical climates have been observed to reconstitute their ancestral woody or evergrowing habit (Okubo et al., 2000).

\subsubsection{Seasonal cycle of dormancy}

During autumn, just before growth cessation in winter, paradormancy marks the first step to a deeper dormant state. When the terminal bud is formed, auxin production and transport imposes a basitonic gradient of bud growth ability in axillary buds (Champagnat et al., 1975; Wareing, 1956). From the beginning of March to the end of August, removal of the apical bud allows the growth of the axillary buds. The same effect is obtained with defoliation from August to September while is totally ineffective later, being an isolated axillary bud unable to resume growth under favourable conditions. Between September and November, depending on climatic conditions, the bud break ability is null, due to endodormancy induction. 


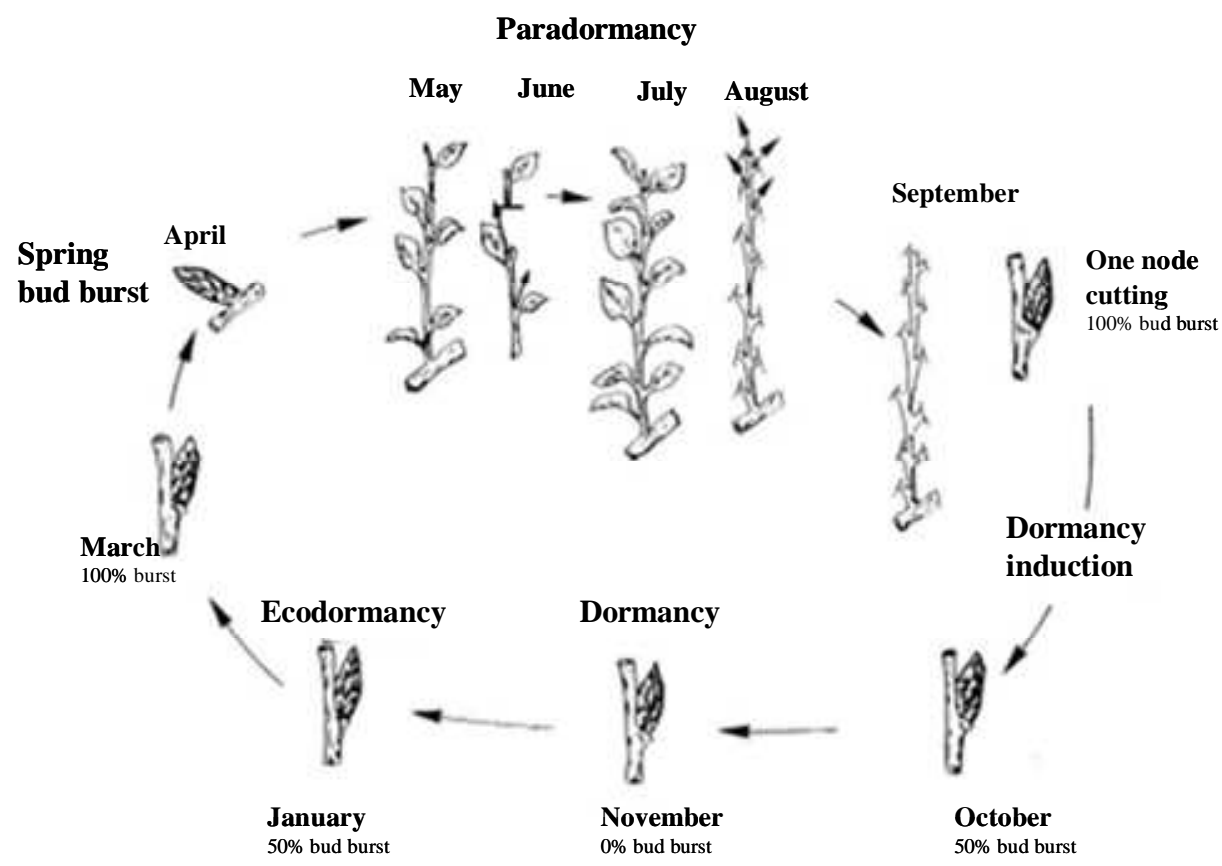

Figure 1.1 Development cycle of axillary buds on a tree shoot. From April to August, the bud is inhibited by paradormancy: a simple decapitation allows immediate growth resumption. But progressively, decapitation and defoliation are both needed to obtain the same result, and finally in September, both treatments have no result. True dormancy appears on October., as shown by the dramatic decrease in bursting ability of buds on 'one-node cutting' but it is released in January. (Based on Champagnat 1989).

The plant, in a first step, develops a moderate resistance to cold that increases considerably after leaf senescence and abscission as a response to lower temperatures (Perry, 1971). From this moment the tree is considered to be endodormant. Once chilling requirements are fulfilled and climatic conditions are favourable $\left(25^{\circ} \mathrm{C}\right)$, buds need only 2 weeks for bud break (Figure 1.1).

\subsubsection{Environmental and physiological factors}

The first studies devoted to bud dormancy were held during the 50's and 60's, with a relevant dedication to hormones that were thought to be the cause of dormancy establishment. Hemberg's (1949) studies showed that an endogenous substance called "dormin" was involved in bud dormancy induction and its synthesis was a plant response to environmental cues (Eagles \& Wareing, 1963). This "dormin" was later named abscisic acid (ABA).

Evidences in favour and against $\mathrm{ABA}$ as dormancy inductor opened the question whether $\mathrm{ABA}$ was more involved in increase freezing tolerance than dormancy regulation (Welling et al., 1997; Rinne et al., 1998; Mielke \& Dennis, 1978; Trewavas \& Jones, 1991; Tanino, 2004). A relationship between $\mathrm{ABA}$ and water content under SD or dormancy induced by water stress was 
observed in Betula pubescens, Prunus persica, Vitis vinifera and Vitis riparia in buds and cortex tissue (Erez et al., 1998; Fennel \& Line, 2001; Rinne et al., 1994; Welling et al., 1997; Koussa et al., 1998), suggesting a link between ABA content and water status with bud dormancy depth (Tamura et al., 1993). After dormancy establishment, a reduction of free water and an accumulation of dehydrins were observed, improving plant tolerance to freezing.

A first connection between day-length shortening and dormancy induction was observed by Garner and Allard (1923), and later confirmed by others (Kramer et al., 1936; Downs \& Bothwick, 1956; Nithsch, 1957; Weieser, 1970; Allona et al., 2008). In photoperiod-insensitive varieties and Euphorbia esula low temperatures replaces the effect of SD (Heide \& Pestrud, 2005; Horvath 2009), as it was also described in strawberry (Ito \& Saito, 1962; Guttridge, 1985). Went $(1948,1953)$ proposedthe term thermoperiodism to indicate the importance of the variation of temperature between day and night. A more recent review by Tanino (2010) raises the hypothesis of the existence of two separated processes involved in dormancy induction in northern ecotypes: one driven by low temperatures while another induced by warm temperature-photoperiod ensuring dormancy development and cold adaptation under both favourable and unfavourable conditions. This hypothesis could explain the different and controversial responses of dormancy to warm and low temperatures described in the literature until now.

Concomitantly with dormancy establishment, water mobility decreases and hydrophilic molecules accumulate (Faust et al., 1995; Erez et al., 1998). Simultaneously, plasmodesmata are blocked by 1,3 $\beta$-glucan (Rinne et al., 2001; Rinne \& Van der Schoot, 2003) and calcium depositions (Jian et al., 1997), and a change in aquaporin gene expression is reported in peach bud (Yooyongwech et al., 2008). Chilling, on the other side, is responsible for restoring symplastic connections by enhancing production of 1,3 $\beta$-glucanase. This process is supposed to be due to gibberellins (GA) production that induce 1,3 $\beta$-glucanases genes transcription as shown in tobacco (LeubnerMetzger et al., 1996).

After growth cessation and under low temperature conditions starch is converted to maltose and simple hexoses, with accumulation in stems and buds (Rinne et al, 1994; Kuroda \& Sagisaka, 1993). Some evidences suggest a role of sucrose and other sugars as signalling molecules in euphorbia, poplar and aspen (Horvath et al., 2002; Olsen et al., 1997; Erikkson et al., 2000). Sugars have been described to interact with ABA and GA during the formation of potato tuber, an organ that also undergoes dormancy processes (Xu et al., 1998). 
Other hormones different from ABA have been related to dormancy maintenance and release. Ethylene has been shown to interact with ABA during bud set and dormancy, as observed in an ethylene-insensitive transgenic birch under SD conditions (Ruonala et al., 2006). Ethylene is considered as an intermediate between light and ABA signals, hypothetically activated by transient low hexose pools (Ruttink et al., 2007).

GA has been proposed as ABA antagonist in growth processes. Under long day-length photoperiod (LD) GA accumulates, accelerating growth. On the contrary, SD has been shown to block certain steps in biosynthesis of GA, leading to growth cessation in poplar trees (Olsen et al., 1997; Eriksson, 2000).

Auxins and cytokinins are involved in bud apical dominance (Rohde et al., 2000). Auxin is also required to maintain the cambium in a meristematic state whereas its sensitivity is reduced during dormancy (Schrader et al., 2003).

Coville was the first, in 1920, to observe chilling requirements effects. He reported that certain native bushes from Washington D.C. remained completely dormant under warm controlled conditions, thus concluding that plants wouldn't resume normal growth in the warm weather without a period of chilling (Coville, 1920). An incomplete fulfilment of chilling requirements causes bud break delay, low bud break rate, lack of uniformity of leafing and blooming, and higher flower-bud drop, that directly influence yield and plant architecture, including a decrease in fruit commercial quality (Erez, 2000; Legave et al., 1982; Viti \& Monteleone, 1991, 1995; Topp et al., 2008). On the other hand, an early fulfilment of chilling requirements in cold regions may increase the risk of spring frosts.

\subsubsection{Economical importance of dormancy}

The incomplete accumulation of chilling still represents a challenge for fruit crop production in temperate and warm climates, because most of the species and cultivars of temperate areas were originated and cultivated between the parallels 34 and 48 of the northern hemisphere (Faust. 2000).

Mediterranean climate area includes Mediterranean Sea borderlands, central and coastal southern California, central Chile, the southern tip of Africa, and part of the southernmost of Australia (Figure 1.2). These locations concentrates the early fruit production that initiates the commercial season, where a high interest to obtain new varieties adapted to this climate exists (Topp et al., 
2008). The expected changes in World climate conditions confer to dormancy and stress processes an increasing relevance, and represents a great challenge for plant breeders worldwide (Luedeling et al., 2011).

Several strategies have been developed to break bud dormancy such as over tree sprinkling of water, shading and defoliation. But the effectiveness of these treatments depends on the time of application. Defoliation, for example, triggers bud break only when performed before endodormancy (Saure, 1973; Janick, 1974; Edwards, 1987). In tropical climates, another agronomical practice is the cultivation at high altitudes that may help to fulfil chilling requirements (Arora et al., 2003).

Chemicals products as hydrogen cyanamide (HC) have also been used to overcome dormancy entrance, with some disadvantages as phytotoxicity and certain environmental impact. With such perspective, the development of new low chilling varieties represents an interesting solution that would minimize the negative ecological impact of chemical dormancy breaking agents.

Maybe for these reasons, in the last 20-30 years the interest on plant bud dormancy has increased, as indicated by the different international symposia emphasizing the complexity and relevance of this process (Corvallis, Oregon USA 1995; Angers, France in 2000; Wageningen, The Netherlands 2004 and Fargo, North Dakota USA 2009). Definitely, a better basic knowledge of dormancy will contribute in a fundamental way to the development of new varieties.

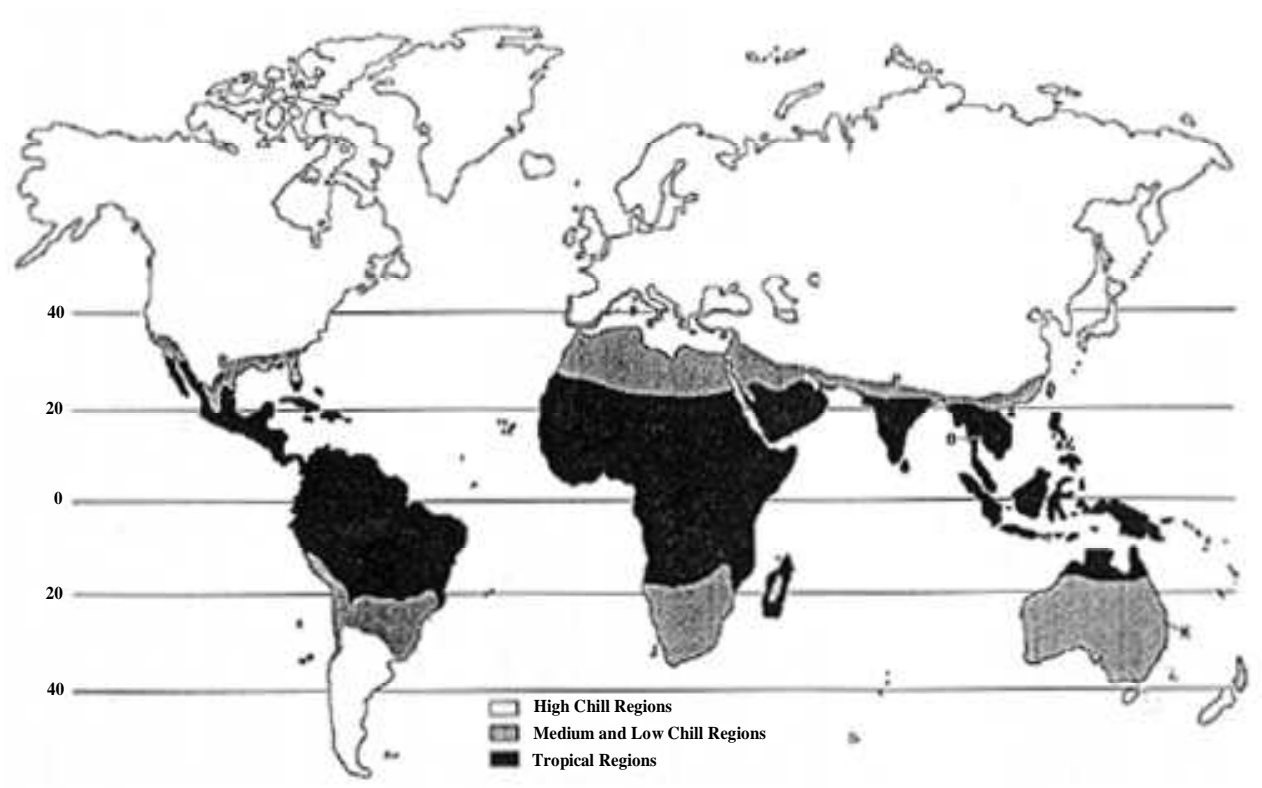

Figure 1.2 Worldwide distribution of medium and low chill region of major stone fruit breeding programs. (adapted from Byrne et al., 2000). 


\subsection{Climatic models for dormancy release}

Once the relationship between dormancy release and the accumulation of low temperatures was established (Coville, 1920), bud dormancy release models started to be developed to determine in which way climate influences the fulfilment of chilling requirements. The effective temperature affecting dormancy breaking was estimated to be $7.2^{\circ} \mathrm{C}$, approximated in certain cases to $7^{\circ} \mathrm{C}$ (Samish et al., 1954; Vegis et al., 1964; Weldon et al., 1934). Initially, temperature was considered the only major influence on dormancy release, and chilling requirement was consolidated as a parameter with a practical use to establish the success of a cultivar in a certain environment (Samish \& Lavee, 1962). The first models based on the linear accumulation of chilling hours (Weinberger, 1950) soon demonstrated their limitations, as chilling requirement measurements were highly dependent on the year and location. A first improvement was provided by Richardson (1974) with the Utah Model that attributed different chill unit values to temperature ranges. Saure (1985) proposed a dual model considering a dual temperature action on dormancy; in a first phase low temperatures support the establishment of dormancy while in a second phase it contributes to dormancy release. This duality was also considered by Cesaraccio et al. (2004), who distinguished chilling days (from harvest to bloom) from antichilling days (during quiescence). Gradually, different models were developed taking into account bud sensitivity to temperature following its dormancy-stage (Fuchigami et al., 1987), the interaction between photoperiod and temperature (Hanninen et al., 1995), as well as diurnal and nocturnal temperature differences (Sugiura et al., 2002).

An adaptation of the Utah Model to warm climates (Dynamic model) was developed in Israel (Fishman et al., 1987a; 1987b). In this model chilling time is accumulated in two steps. A first accumulation of an intermediate product is promoted by chilling temperatures while warm temperatures have an opposite effect on this process. Once a sufficient amount of intermediate product is accumulated, Chill Portions are continuously accumulated. Then, after a period of cold, moderate temperatures have a positive effect on dormancy release (Erez \& Couvillon, 1987). Several modifications to the Utah Model including temperature effects not previously considered were successively proposed. Thus, a more complex and accurate model arose taking into account different climatic conditions and crops: peach in Israel (Erez, 2000; Erez \& Lerner, 1990; Fishman et al., 1987 a, 1987b), ornamental peach in Japan (Pawasut et al., 2004), kiwifruit (Allan et al., 1997), Eucalyptus nitens (Gardner \& Bertling, 2005), peach in South Africa (Allan et al., 1995), peach in Chile (Perez et al., 2008) and in France (Balandier et al., 1993a), cherry 
(Alburquerque et al., 2008), almond (Egea et al., 2003), apricot in Spain (Ruiz et al., 2007) and Italy (Viti et al., 2010), walnut in California (Luedeling et al., 2009e) and apple in northern Italy (Valentini et al., 2001). In particular the Dynamic model along with the Chill Hours and the Utah Models failed in tropical climatic conditions of Reunion Island (Balandier et al., 1993). This could mainly be due to the lack of biological and physiological basis: the majority of the models are developed with detached shoots or potted trees in growth chamber trying to simulate their behaviour in open field (Campoy et al., 2011a).

As a conclusion, bud dormancy release models are as accurate as our understanding of the cellular mechanisms underlying dormancy release (Arora et al., 2003). A deeper knowledge on the molecular and physiological mechanisms controlling dormancy would contribute to develop more robust models for dormancy evaluation; as an example by considering the interaction between photoperiod and temperature into chill model (Campoy et al., 2011a).

\subsection{Common feature between bud and seed dormancy}

During the growing season also seeds and tubers undergo dormancy. The growth of bud and embryo meristems is strictly regulated by dormancy mechanisms until environmental conditions are optimal for long-term survival. Dormancy is then released after a period of chill in both seeds and buds suggesting a common mechanism of control. This chilling treatment in seeds is called stratification. Insufficient cold stratification of seeds causes deformations in the growth habit as physiological dwarfing (Pollock, 1962).

In most popular model organisms, physiological dormancy integrates contributions from the embryo and the seed coat, being the coat component at least partially due to the mechanical resistance to breakage of endosperm and testa layers. In fact some species require scarification or fire, since smoke contains some dormancy breaking compounds as nitrogen oxides and a butenolide that stimulates germination.

Several recent findings support the hypothesis that germination control by seed covering layers is promoted by the action of several cell-wall modifying proteins, as 1,3 $\beta$-glucanases. Similar enzymes are involved in bud dormancy, producing degradation of callose deposition in the neck region of plasmodesmata (Rinne et al., 2001; 2011). In the cases of seeds, they could facilitate endosperm rupture of seeds, promoting cell separation (Finch-Savage et al., 2006).

The ratio of the hormones $\mathrm{ABA}$ and GA is considered a relevant factor regulating seed dormancy processes (Kucera et al., 2005). Dormancy maintenance depends on high ABA:GA ratios while its 
release occurs with low ABA:GA (Cadman et al., 2006). In addition to hormone content and synthesis, the transition from a dormant to a non-dormant state is characterized by an altered sensitivity to ABA and GA. Other hormones as ethylene, brassinosteroids, auxin and cytokinins have been also proposed to affect dormancy and germination (Finkelstein et al., 2008).

The molecular factors and pathways conditioning seed dormancy status have been enumerated in several recent reviews (Bentsink et al., 2007; Finkelstein et al., 2008; Holdsworth et al., 2008; North et al., 2010; Finch-Savage et al., 2006).

Early studies showed that the B3 class transcription factors encoded by VIVIPAROUS 1 (VP1) in maize and ABA-INSENSITIVE 3 (ABI3) in Arabidopsis are involved in seed development and dormancy (McCarty et al., 1991; 1995; Giraudat et al., 1992).

At hormonal level, bud dormancy resembles seed dormancy (Powell 1987). Multiple physiological and transcriptomic studies (Rohde et al., 2002; Arora et al., 2003; Horvath et al., 2003; Rohde \& Balherao, 2007) support the role of ABA in bud dormancy events. Transgenic poplars overexpressing and downregulating PtABI3 suggested a role of $A B I 3$ in bud development influencing cellular differentiation of vegetative tissues; in addition to its role on seed dormancy (Rohde et al., 2002).

The modification of the chromatin structure contributes to the transcriptional regulation of dormancy in seeds. Single and double mutants in the HISTONE MONOUBIQUITINATION genes (HUB1 and HUB2) coding for C3HC4 RING finger proteins with histone modifying activity showed a decreased dormancy phenotype (Liu et al., 2007). The identification of two histone deacetylases further suggested that chromatin structure is involved in the control of seed development (Tanaka et al., 2008).

\subsection{Genetic and molecular aspects of dormancy process}

\subsubsection{Genetic studies and mapping of dormancy associated loci}

Classical genetic approaches for the description of traits related to dormancy contributed to the understanding of the dormancy process. In blueberry, for example, cold hardiness trait best fits in a simple additive dominance model, while chilling requirement is controlled by two genes with equal effect (Rowland et al., 1999). Moreover, two genetic studies suggested that one major gene controlled the low chilling requirement trait in apple and apricot (Hauagge \& Cummins, 1991; Tzonev \& Erez, 2003). 
A Quantitative Trait Loci (QTL) mapping of bud set and bud flush in Populus suggested the existence of respectively three and six QTLs (Frewen et al., 2000), which was more recently confirmed in four different pedigrees (Rohde et al., 2011). PHYB2 and ABIIB genes, involved respectively in the perception of photoperiod and ABA response signal, mapped to two of these QTLs affecting bud set and bud flush (Frewen et al., 2000).

Two QTLs for blooming date were detected on LG2 and LG7 (Linkage Group) by Dirlewanger et al. (1999) in a peach F2 population. One major gene (Late blooming or Lb) was mapped on LG4 by Ballester et al. (2001) in an almond F1 population; and one QTL for blooming time was mapped on LG4 by Verde et al. (2002) in a peach backcross (BC1) population. Fan et al. (2010) identified 20 QTLs associated to chilling requirement (CR), heat requirement (HR) and blooming date traits (BD) after evaluating a $F_{2}$ population of peach for 2 consecutive years. The strongest QTL found in this work mapped on linkage group 1 , in a region containing the locus responsible for the non-dormant phenotype of the evergrowing (evg) mutant of peach (Fan et al., 2010).

In apricot, QTLs analysis of a cross between "Perfection" (high chilling variety) and "A1740" (low chilling variety) showed the most significant QTLs on LG1, LG5 and LG7 (Olukolu et al., 2009); while Campoy et al. (2011b) identified one major QTL for flowering time on LG5, linked to UDAp423r and AMPA-105 SSRs loci.

Additionally, a candidate gene approach associated two genes homologous to Arabidopsis LEAFY and MADS-box genes to two QTLs in almond (Silva et al., 2005), indicating that our knowledge on the genetic control of flowering time in annual plants may be applied to perennial tree species.

Few molecular markers have been associated to dormancy yet. A SCAR identified in red osier dogwood (Cornus sericea L.) was reported to be effective (>92\%) to distinguish northern from southern dogwood ecotypes, differing in temperature-induced dormancy (Svedsen et al., 2007).

\subsubsection{Molecular aspects of dormancy process.}

\subsubsection{The Vernalization model in Arabidopsis and cereals}

The reproductive success of a plant depends on the synchronization of flowering time with the optimal environmental conditions. To do so certain Brassicaceae and cereals have developed a signal perception and transduction pathway that senses prolonged periods of cold during winter or vernalization.

A key gene in the regulation of vernalization in Arabidopsis is FLOWERING LOCUS C (FLC). $F L C$ is a $M A D S$-box transcription factor that acts as a repressor of floral transition by repressing 
the floral integrator FLOWERING LOCUS T (FT) and SUPPRESSOR OF CONSTANS 1 (SOC1) (Searle et al., 2006; Figure 1.3). The cold-dependent induction of VERNALIZATION INSENSITIVE 3 (VIN3) during vernalization results in stable repression of FLC. When FLC is repressed, FT expression is induced under long days condition, and the FT protein is transported from the leaf to the shoot apex where induces flowering (Corbesier et al., 2007). Repression of $F L C$ ends with meiosis, allowing the vernalization response in the next generation (Sheldon et al., 2000).

In cereals, VERNALIZATION1 (VRN1) gene coding for a MADS-box transcription factor related to the Arabidopsis genes APETALA1 (AP1), FRUITFULL (FUL) and CAULIFLOWER (CAL) regulates meristem identity favouring the vegetative to reproductive transition (Yan et al., 2003). $V R N 1$ expression increases quantitatively as a response to cold, just in an opposite manner to FLC (Oliver et al., 2009). Resetting of VRN1 expression occurs in autumn and in the progeny (Yan et al., 2003; Sasani et al., 2009).

VERNALIZATION2 (VRN2) encodes for a zinc-finger protein without clear homologues in Arabidopsis that is downregulated during prolonged periods of cold. VRN1 and VRN2 act respectively as positive and negative regulators of the floral induction (Figure 1.3). Loss-offunction mutations in VRN2 confer a spring growth habit in wheat (that responds to LD photoperiod) (Trevaskis et al., 2003; Yan et al., 2004). However, vrn2 mutants still respond to cold and induce VRN1 after vernalization (Karsai et al., 2005).
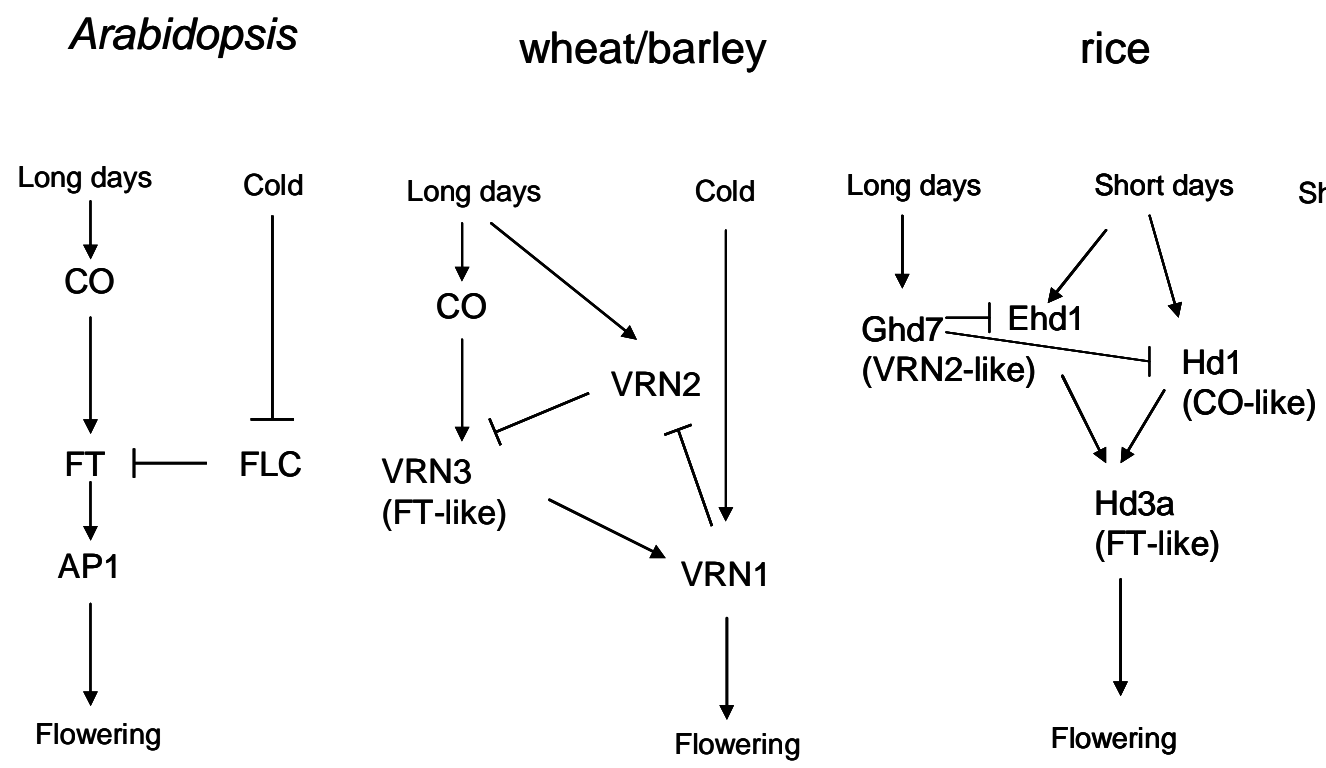

peach

Figure 1.3 Genetic pathway controlling flowering in Arabidopsis, wheat/barley, rice and peach. Arrows show promoting effects, T-bars show repressing effects (Trevaskis et al., 2007; Alonso-Blanco et al., 2009; Jiménez et al., 2010b). 
The expression of VERNALIZATION3 (VRN3) gene, considered as the homolog of FT in cereals, is up-regulated under LD conditions in wheat and barley as well as VRN2, whereas FT in rice is up-regulated under SD (Izawa et al., 2002).

While the day-length response is conserved between Arabidopsis and temperate cereals (wheat and barley), with CONSTANS (CO) inducing FT expression in specific day-lengths to promote flowering, the mechanism that integrates vernalization into this photoperiodic response is slightly different. In Arabidopsis a single gene, FLC, is responsible for regulating flowering by means of FT repression, while in cereals $V R N 1$ and $V R N 2$ are performing this role. The first is induced by prolonged cold while the second one responds to photoperiod. (Trevaskis et al., 2007b).

Rice differs from Arabidopsis and temperate cereals in that the flowering pathway only depends on the photoperiod and no vernalization response has been reported. Under short-day conditions, expression of the $\mathrm{CO}$ orthologue Hdl(Heading date 1) and Ehdl(Early heading date 1), with no homologues in the Arabidopsis flowering pathway, promotes flowering in rice (Figure 1.3). Both genes induce the expression of $\mathrm{Hd} 3 \mathrm{a}$ (Heading date $3 a$ ), a rice orthologue of Arabidopsis FT (Izawa et al., 2007). Under long days conditions, expression of the VRN2-like gene Ghd7 (Grain number, plant height and heading date 7) represses flowering (Itoh et al., 2010).

\subsubsection{Chromatin modification in vernalization}

In both, Arabidopsis and cereals, the transcription of key vernalization genes is regulated by similar epigenetic mechanisms. In Arabidopsis, the stable down-regulation of FLC by vernalization is associated to specific histone modifications involving di- and tri-methylation of histone H3 lysine-27 (H3K27me2, H3K27me3), and methylation of H3 lysine-9 and H4 arginine3. On the opposite, marks associated to active transcription such as $\mathrm{H} 3$ acetylation and $\mathrm{H} 3$ lysine4 di- and trimethylation (H3K4me2, H3K4me3) are removed (Bastow et al., 2004; Sung et al., 2004; Finnegan et al., 2005; Sung et al., 2006; Finnegan et al., 2007; Schmitz et al., 2008; Doyle \& Amasino, 2009).

In temperate cereals, VRN1 is up-regulated during vernalization, coinciding with a reduction in H3K27me3 and an increase in H3K4me3 (Oliver et al., 2009; Hemming \& Trevaskis, 2011).

The Polycomb Repressive Complex 2 (PRC2) is involved in H3K27 trimethylation and stable chromatin repression of Arabidopsis FLC during winter and wheat VRN1 during summer (Hemming et al., 2009; Oliver et al., 2009). Chromatin state is restored at spring to ensure the plant is able to respond to vernalization again the next year. Different Polycomb subunits similar 
to proteins from animals are combined in different ways to constitute specific PRC2 complexes involved in many aspects of plant development, as vernalization, seed germination and the transition from juvenile to adult phase (Hennig \& Derkacheva, 2009).

\subsubsection{The dormancy pathway in peach}

In perennial plants SHORT VEGETATIVE PHASE (SVP)-like/AGAMOUS-LIKE24 (AGL24)-like MADS-box genes named DORMANCY ASSOCIATED MADS-box (DAM) have been found related to dormancy processes in poplar (Ruttink et al., 2007), raspberry (Mazzitelli et al., 2007), japanese apricot (Yamane et al., 2008), leafy spurge (Horvath et al., 2008) and blackcurrant (Hedley et al., 2010), suggesting similar mechanisms of dormancy control in perennial plants.

In peach (Prunus persica (L.) Batsch.), six tandemly repeated DAM genes were identified in studies employing the evg natural mutant (Bielenberg et al., 2008). The evg mutant, first identified in Mexico (Rodriguez et al., 1994), maintains apical growth and persistent leaves during the period of low temperatures and short days, presenting a relative low frost resistance (Arora et al., 1996; Arora \& Wisniewski, 1994). On the contrary, lateral buds show a wild-type behaviour.

The evg locus has been mapped and identified in a genomic region of $132 \mathrm{~kb}$ in the wild-type, that was demonstrated to be partially deleted in evg in four of the six clustered MADS-box genes (Bielenberg et al., 2004; 2008).

The first report on QTL mapping of dormancy-related variables in peach identified twenty QTLs for chilling requirements $(\mathrm{CR})$, bloom date $(\mathrm{BD})$ and heat requirement (HR). The main QTL associated to the three traits localizes in the evg region, indicating that DAM genes are strong candidates for these traits (Fan et al., 2010). The publication of the peach genome (IPGI http://www.rosaceae.org/peach/genome) allowed the identification of the exact position of this region, although $D A M 1, D A M 2$ and DAM3 transcript models are not correctly annotated in the public repository (Figure 1.4)

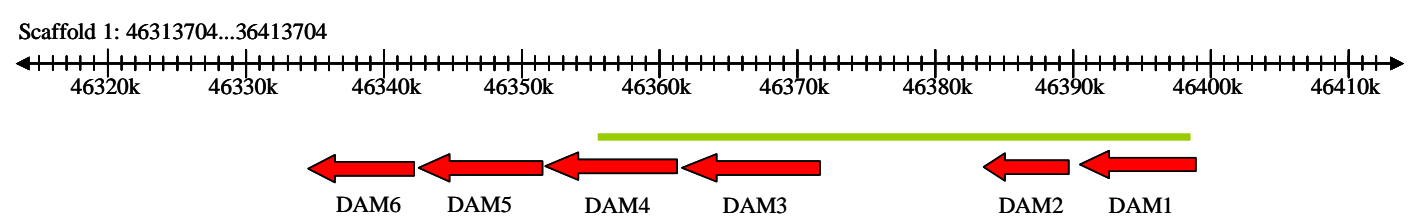

Figure 1.4 Physical map representation of DAM genes on the peach genome. Arrows indicates the sense orientation and green bar indicates the deletion in the evg mutant (adapted from Bielenberg et al., 2008). 
The deletion in the evg mutant affected a region containing four genes and caused the lack of transcription of six DAM genes (Bielenberg et al., 2008). This fact suggests a possible crossregulation between the four deleted genes and the other two.

Four different seasonal expression patterns have been observed indicating specific roles of these genes in growth and development (Li et al., 2009). The expression of DAM1, DAM2 and DAM4 was more closely associated to terminal bud formation, although all six genes showed seasonal expression changes. Gene expression of $D A M 3, D A M 5$ and $D A M 6$ was strongly up-regulated by SD and successively reduced by chilling temperatures (Li et al., 2009). DAM5 and DAM6 levels directly correlated with the time required for bud break so they have been proposed as quantitative repressors of bud dormancy release (Jiménez et al., 2010b). The down-regulation of these genes is supposed to be necessary to reset dormancy mechanism for the next year (Hemming \& Trevaskis, 2011). These observations were further confirmed by Yamane et al. (2011) in Prunus persica treated with cyanamide, but also in other woody plants as Japanese apricot (Prunus mume) (Yamane et al., 2008), poplar (Druart et al., 2007), raspberry (Mazzitelli et al., 2007) and leafy spurge (Horvath et al., 2008). In a recent work, Sasaki et al. (2011) focused on PmDAM6 as a candidate gene to control dormancy in Japanese apricot. Transgenic poplar constitutively expressing PmDAM6 showed growth cessation and terminal bud set in environmental conditions favorable to growth.

Since an epigenetic mechanism regulates the expression of FLC in Arabidopsis and VRN1 in cereals, it is expected a similar control of bud dormancy in perennial trees. Interestingly the DAM1 gene of leafy spurge shows altered levels of H3K27me3 and H3K4me3 at two different dormancy stages (Horvath et al., 2010).

\subsubsection{Transcriptomic approaches}

Genomics offers useful tools for the study of biological issues in species showing difficulties for genetic approaches (Rowland et al., 1997; Wisniewsky et al., 2004). Several studies have been dedicated to dormancy entrance, release or maintenance in different species as blueberry (Dhanaraj et al., 2004), Rhododendron (Wei et al., 2005), Populus (Schrader et al., 2004), raspberry (Mazzitelli et al., 2007) and grapevine (Mathiason et al., 2008), as summarized in Table 1.1 .

The most relevant transcriptomic studies on dormancy release are described and the genes classified by ontological categories: membrane alterations, sugar metabolism and carbohydrate 
catabolism, stress response and detoxification, biosynthesis of hormones and hormone receptors, light perception, cell cycle, division and growth, transport genes, regulation of gene expression and vernalization pathway.

Table 1.1 Genomic studies in perennial plants related to dormancy

\begin{tabular}{|c|c|c|c|c|}
\hline Method & $\mathrm{N}$ of ESTs/gene/part of the plant & Treatments & Species & Reference \\
\hline Microarray & $\begin{array}{l}1400 \text { unigenes differentially } \\
\text { expressed }\end{array}$ & $\begin{array}{l}\text { crown buds collected } \\
\text { monthly 2002-2006 }\end{array}$ & $\begin{array}{l}\text { Leafy spurge } \\
\text { (Euphorbia } \\
\text { esula) }\end{array}$ & $\begin{array}{l}\text { Horvath } \\
\text { et al., } 2002\end{array}$ \\
\hline Microarray & $\begin{array}{l}4270 \text { ESTs } 12 \text { randomly selected } \\
\text { differential expressed genes }\end{array}$ & $\begin{array}{l}\text { bud releasing from } \\
\text { dormancy }\end{array}$ & $\begin{array}{c}\text { Grape } \\
\text { (Vitis } \\
\text { vinifera) }\end{array}$ & $\begin{array}{l}\text { Pacey Miller } \\
\text { et al., } 2003\end{array}$ \\
\hline Microarray & $\begin{array}{l}7 \text { cDNA libraries } 12376 \text { clones } \\
\text { sequenced, differential expression of } \\
\text { SVP/AGL24-type MADS-box gene }\end{array}$ & $\begin{array}{l}\text { Induction of dormancy } \\
\text { (leaf senescence) }\end{array}$ & $\begin{array}{c}\text { Popolus } \\
\text { genus }\end{array}$ & $\begin{array}{l}\text { Andersson } \\
\text { et al., } 2004\end{array}$ \\
\hline EST sequencing & $\begin{array}{c}430 \text { and } 483 \text { EST clones from } 2 \\
\text { libraries }\end{array}$ & $\begin{array}{l}\text { Non-acclimated and } \\
\text { after } 600 \text { chilling units } \\
\text { floral buds }\end{array}$ & $\begin{array}{l}\text { Blueberry } \\
\text { (Vaccinium } \\
\text { corymbosum) }\end{array}$ & $\begin{array}{l}\text { Dhanaraj } \\
\text { et al., } 2004\end{array}$ \\
\hline EST sequencing & 4500 full lenght EST clones & $\begin{array}{l}\text { dehydratation, high } \\
\text { salinity, chilling, heat, } \\
\text { ABA, H2O2 in leaves }\end{array}$ & $\begin{array}{l}\text { Poplar } \\
\text { (Populus } \\
\text { nigra } v . \\
\text { Italica) }\end{array}$ & $\begin{array}{l}\text { Nanjo } \\
\text { et al., } 2004\end{array}$ \\
\hline $\begin{array}{l}\text { Microarray } \\
\text { (POP1 array) }\end{array}$ & $\begin{array}{l}33000 \text { ESTs; } 1598 \text { contigs and } 1478 \\
\text { singletons from dormant; } 950 \\
\text { contigs and } 746 \text { singletons }\end{array}$ & $\begin{array}{l}\text { Summer/autumn } \\
\text { cambium (active } \\
\text { growth/dormancy) }\end{array}$ & $\begin{array}{l}\text { Poplar } \\
\text { (Popolus } \\
\text { tremula) }\end{array}$ & $\begin{array}{l}\text { Schrader } \\
\text { et al., } 2004\end{array}$ \\
\hline EST sequencing & 15574 contigs +6804 singlet & 16 different libraries & $\begin{array}{l}\text { Poplar } \\
\text { (Popolus } \\
\text { tremula) }\end{array}$ & $\begin{array}{l}\text { Sterky } \\
\text { et al., } 2004\end{array}$ \\
\hline Microarray & 2171 ESTs & $\begin{array}{l}\text { seasonal changes in } \\
\text { earlywood-latewood } \\
\text { from xylem and shoot } \\
\text { tip library }\end{array}$ & $\begin{array}{l}\text { Loblolly pine } \\
\text { (Pinus teada) }\end{array}$ & $\begin{array}{l}\text { Yang \& } \\
\text { Loopstra } \\
2005\end{array}$ \\
\hline cDNA from $\mathrm{SSH}$ & $\begin{array}{c}10 \text { SSH libraries, } 108 \text { unigenes, } 8 \\
\text { randomly selected differential } \\
\text { expression genes }\end{array}$ & $\begin{array}{l}\text { bark tissue at } 5^{\circ} \mathrm{C} \text { and } \\
25^{\circ} \mathrm{C} \text { under } \mathrm{SD} \text { or } \mathrm{LD}\end{array}$ & $\begin{array}{l}\text { Peach } \\
\text { (Prunus } \\
\text { persica) }\end{array}$ & $\begin{array}{l}\text { Bassett } \\
\text { et al., } 2006\end{array}$ \\
\hline $\begin{array}{l}\text { SSH / nylon } \\
\text { membrane } \\
\text { hybridization }\end{array}$ & 801 ESTs 233 unigenes & $\begin{array}{l}\text { buds during budbreak } \\
\text { (6 stages) and shoot } \\
\text { outgrowth }\end{array}$ & $\begin{array}{l}\text { Sessile oak } \\
\text { (Quercus } \\
\text { petraea) }\end{array}$ & $\begin{array}{l}\text { Derory } \\
\text { et al., } 2006\end{array}$ \\
\hline SSH & $\begin{array}{l}516 \text { clones differentially expressed } \\
\text { from } 2 \mathrm{SSH} \text { libraries }\end{array}$ & $\begin{array}{l}\text { dormant and growing } \\
\text { crown buds }\end{array}$ & $\begin{array}{l}\text { Leafy spurge } \\
\text { (Euphorbia } \\
\text { esula) }\end{array}$ & $\begin{array}{l}\text { Jia } \\
\text { et al., } 2006\end{array}$ \\
\hline Microarray & Idem from Schrader et al., 2004 & $\begin{array}{l}\text { Cambial meristematic } \\
\text { cells during } \\
\text { dormancy-activity } \\
\text { cycle }\end{array}$ & $\begin{array}{l}\text { Aspen } \\
\text { (Populus } \\
\text { tremula) }\end{array}$ & $\begin{array}{l}\text { Druart } \\
\text { et al., } 2007\end{array}$ \\
\hline $\begin{array}{l}\text { Microarray and } \\
\text { Northern blot } \\
\text { Hybridization }\end{array}$ & $\begin{array}{l}\text { 5516 ESTs Differential expression } \\
\text { of } 9 \text { genes }\end{array}$ & $\begin{array}{l}\mathrm{HC} \text { treatment/ control } \\
\text { in budbreak }\end{array}$ & $\begin{array}{c}\text { Grape } \\
\text { (Vitis } \\
\text { vinifera) }\end{array}$ & $\begin{array}{l}\text { Keilin } \\
\text { et al., } 2007\end{array}$ \\
\hline Microarray & $\begin{array}{l}1469 \text { ESTs from buds from nodes } 3 \\
\text { to } 12\end{array}$ & $\begin{array}{l}0,500,1000,1500 \text { and } \\
2000 \text { hours of chilling }\end{array}$ & $\begin{array}{c}\text { Grapevine } \\
\text { (Vitis riparia) }\end{array}$ & $\begin{array}{l}\text { Mathiason } \\
\text { et al., } 2009\end{array}$ \\
\hline Microarray & $\begin{array}{c}5.300 \text { screened clones from } 2 \\
\text { cDNAs libraries, } 88 \text { differentially } \\
\text { expressed unigenes }\end{array}$ & $\begin{array}{l}\text { endodormant vs } \\
\text { paradormant bud }\end{array}$ & $\begin{array}{l}\text { Raspberry } \\
\text { (Rubus } \\
\text { idaeus) }\end{array}$ & $\begin{array}{l}\text { Mazzitelli et } \\
\text { al., } 2007\end{array}$ \\
\hline $\begin{array}{l}\text { cDNA-AFLP } \\
+ \text { RT-PCR }\end{array}$ & $\begin{array}{c}592 \text { TDF (Transcript-Derived } \\
\text { Fragments) }\end{array}$ & $\begin{array}{c}\text { seasonal changes } \\
\text { throught } 115 \mathrm{~d} \\
\text { covering all dormant } \\
\text { periodin axillary and } \\
\text { apical buds }\end{array}$ & $\begin{array}{c}\text { Poplar } \\
\text { (Popolus } \\
\text { tremula } x \\
\text { Popolus alba) }\end{array}$ & $\begin{array}{l}\text { Rohde } \\
\text { et al., } 2007\end{array}$ \\
\hline
\end{tabular}




\begin{tabular}{|c|c|c|c|c|}
\hline $\begin{array}{l}\text { Microarray } \\
\text { (TIGR potato } \\
\text { microarray vers. } \\
3 \text { and } 4 \text { ) }\end{array}$ & $\begin{array}{c}\text { TIGR potato microarray, } 47 \\
\text { upregulated genes in natural } \\
\text { dormancy release, } 589 \mathrm{cDNA} \text { after } 1 \\
\text { day BE treatment, } 319 \mathrm{cDNA} \text { after } 8 \\
\text { days, } 26 \text { down-, } 12 \text { up-regulated } \\
\text { genes. }\end{array}$ & $\begin{array}{l}\text { meristem from tubers } \\
\text { collected in natural } \\
\text { and bromoethane (BE) } \\
\text { dormancy release }\end{array}$ & $\begin{array}{l}\text { Potato } \\
\text { (Solanum } \\
\text { tuberosum) }\end{array}$ & $\begin{array}{l}\text { Campbell et } \\
\text { al., } 2008\end{array}$ \\
\hline $\begin{array}{l}\text { Northern blot } \\
\text { Hybridization }\end{array}$ & $\begin{array}{c}\text { Differential expression of } 7 \text { genes } \\
\text { involved in oxidative stress } \\
\text { mechanism }\end{array}$ & $\begin{array}{l}\text { Heat Shock and HC } \\
\text { treatment on budbreak }\end{array}$ & $\begin{array}{l}\text { Grape } \\
\text { (Vitis } \\
\text { vinifera })\end{array}$ & $\begin{array}{l}\text { Halaly et al., } \\
2008\end{array}$ \\
\hline Microarray & $\begin{array}{l}\text { one SSH library } 185 \text { clones } \\
\text { differentially expressed }\end{array}$ & $\begin{array}{l}\text { buds recollected } \\
\text { during dormancy } \\
\text { release }\end{array}$ & $\begin{array}{l}\text { Tree peony } \\
\text { (Paeonia } \\
\text { suffruticosa) }\end{array}$ & $\begin{array}{l}\text { Xin } \\
\text { et al., } 2008\end{array}$ \\
\hline SSH & 2 SSH libraries, 26 unigenes & $\begin{array}{l}\text { buds endodormant vs } \\
\text { paradormant and } \\
\text { endodormant vs } \\
\text { paradormant }\end{array}$ & $\begin{array}{l}\text { Japanese } \\
\text { apricot } \\
\text { (Prunus } \\
\text { mume })\end{array}$ & $\begin{array}{l}\text { Yamane } \\
\text { et al., } 2008\end{array}$ \\
\hline Microarray & $\begin{array}{l}1582 \text { genes upregulated and } 1116 \\
\text { downregulated }\end{array}$ & buds treated with $\mathrm{HC}$ & $\begin{array}{l}\text { Kiwifruit } \\
\text { (Actinidia } \\
\text { deliciosa) }\end{array}$ & $\begin{array}{l}\text { Walton } \\
\text { et al., } 2009\end{array}$ \\
\hline SSH & $\begin{array}{l}11.520 \text { screened clones, } 106 \\
\text { sequenced contigs, } 23 \text { up-regulated } \\
\text { genes during SD exposure }\end{array}$ & $\begin{array}{l}\text { Growth cessation and } \\
\text { bud dormancy } \\
\text { entrance using the evg } \\
\text { mutant }\end{array}$ & $\begin{array}{l}\text { Peach } \\
\text { (Prunus } \\
\text { persica) }\end{array}$ & $\begin{array}{l}\text { Jiménez } \\
\text { et al., 2010a }\end{array}$ \\
\hline
\end{tabular}

\subsubsection{Genes involved in membrane alterations: cell wall modification and cell expansion}

The composition of plasma membrane proteins varies with the season: in autumn the increase in fatty acid desaturation of membrane lipids and the change in glycoproteins composition contributes to maintain fluidity at low temperatures (Martz et al., 2006; Yoshida et al., 1984).

Cell wall modification enzymes are expressed during the time course of bud dormancy; as extensin-like hydroxyproline glycoproteins are up-regulated at the end of dormancy. In the same period, the transcription of polygacturonase-inhibiting proteins is down-regulated. In fact, dormancy process includes a phase of cell wall restructuration that could be involved in the reestablishment of cell-to-cell communication through plasmodesmata during dormancy release, as observed in birch (Rinne et al., 2001).

\subsubsection{Genes involved in sugar metabolism and carbohydrate catabolism}

In autumn, accumulation of sucrose and starch occurs in response to low and freezing temperatures and, under SD condition, starch is mobilized mostly during the night.

During chilling fulfilment, genes involved in carbohydrate metabolism (enzymes as sucrose synthase, hexose transporter and several genes involved in the processing of glucose-6-phosphate) are inhibited. Mathiason et al. (2009) identified grapevine ESTs with similarity to sucrose synthase, hexose transporter, glyceraldehyde-3-phosphate dehydrogenase and chalcone synthase; as also found in raspberry buds (Mazzitelli et al., 2007). 
These findings support the idea that during the fulfilment of chilling requirement buds reduce their metabolic activity.

Also the induction of a $\mathrm{H}^{+}$ATPase has been described concomitantly with bud break (Mazzitelli et al., 2007). This could be due to the increasing import of sugars needed to restore growth. On the contrary, a decrease in the activity of NAD-SDH (NAD-dependent sorbitol dehydrogenase), responsible for the conversion of unloaded sorbitol to fructose or other metabolites in sink tissue, is observed in raspberry (Mazzitelli et al., 2007) and Japanese pear (Ito et al., 2002).

Sucrose has also been proposed to act as a signalling molecule (Horvath et al., 2002). Dijkwel et al. (1997) and Short (1999) reported that sucrose inhibits phytocrome A (PHYA) signalling in Arabidopsis when combined with overexpression of phytochrome B (PHYB). Moreover this sugar inhibits the growth of leafy spurge crown buds through negative interaction with GA (Horvath 2002).

Rohde et al. (2007), working with poplar, identified 40 genes coding for proteins involved in catabolism and energy generation that were highly expressed during dormancy induction and dormancy maintenance. This observation suggests that lipid, sugar and fatty acid breakdown occurs during the induction of dormancy; not just during dormancy as proposed by previous studies (Sagisaka 1991). The expression of genes involved in polysaccharide cleavage and oligosaccharide production is high during the first phase of dormancy induction, having an osmoprotector function.

\subsubsection{Proteins related to stress or protection responses and detoxification processes}

Renaut et al. (2004) found that deactivation of reactive oxygen species and accumulation of dehydrins were some of the most prominent changes in the transcriptomic profile of poplar trees during seasonal chilling. Bud break is associated to free radical removal through the activation of peroxide scavenging systems such as catalase, ascorbate peroxidase, superoxide dismutase and glutathione reductase (Pacey Miller et al., 2003; Mazzitelli et al., 2007), when oxidative damages are more probable.

$\mathrm{H}_{2} \mathrm{O}_{2}$ is considered an occasional signalling molecule in plants that accumulates in grapevine buds treated with $\mathrm{HC}$, suggesting a function in triggering the expression of genes related to dormancy release.

Dehydrins are the most studied proteins in relation to cold acclimation in woody plants. Although their function has not well been elucidated, their abundance during dehydration in plant suggests a 
role in cellular protection (Ingram \& Barteles, 1996). Their activity could be linked to calcium binding (Alsheikh et al., 2005), as well as to osmoregulation (Nylander et al, 2001; Wisniewsky et al., 1999), and radical scavenging (Hara et al., 2004). The simultaneous overexpression of two dehydrin genes in Arabidopsis (Puhakainen et al., 2004), and a citrus dehydrin in transgenic tobacco resulted in increased freezing tolerance and lipid peroxidation (Hara et al., 2003). The majority of these proteins are induced in response to low temperatures while few are induced under SD conditions, as also reported by Welling et al. (2004) in birch. In peach, a $60 \mathrm{kDa}$ dehydrin was found at a lower concentration in the evg mutant when compared with coldacclimated standard deciduous trees (Arora \& Wisniewski; 1994). Numerous late embryogenesis abundant (LEA) proteins have been identified in different studies in a wide range of tissues (Horvath et al., 2003; Mazzitelli et al., 2007; Schrader et al., 2004; Basset et al., 2006; Jiménez et al., 2010a). Although the function of LEA proteins is not well known at the molecular level, they are supposed to have a role in protecting cells from desiccation and temperature stress.

\subsubsection{Biosynthesis of hormones and hormones receptors}

There is a set of overlapping hormonal signals in response to the environmental and physiological cues that are important in coordinating plant response during dormancy release.

In winter, auxin sensitivity and transport are reduced in poplar and birch (Schrader et al., 2003; Li et al., 2009). The opposite situation is found in potato, where auxin levels increase during dormancy and quickly drop off with dormancy release, suggesting opposite mechanisms involved in auxin production, transport and perception during dormancy (Horvath et al., 2003).

Short days preceding the cessation of apical growth cause a decrease in GA levels (Olsen et al., 1997). Coherently, transcript levels of the poplar gene REPRESSOR of GA1(PtRGA1), highly similar to the repressor of gibberellin response $R G A 1$, are up-regulated in dormant cambium (Schrader et al., 2004; Ruttink et al., 2007). Furthermore, a gene coding for a GA2 oxidase, an enzyme that inhibits the bioactive GAs via hydroxylation, was found increased in winter buds of Prunus mume (Yamane et al., 2008).

The involvement of ABA in dormancy establishment has been reported in poplar buds where genes encoding for ABA biosynthesis are up-regulated after 3 or 4 weeks of SD, coinciding with a transient ABA peak registered 4 weeks after the transition to SD (Ruttink et al., 2007). Moreover transgenic poplar overexpressing ABSCISIC ACID INSENSITIVE 3 (ABI3) doesn't form a terminal bud, highlighting the relevant role of ABA in dormancy acquisition (Rohde \& Balherao, 
2007; Rohde et al., 2002). During winter rest no transcription in genes involved in ABA biosynthesis has been registered, as reported by Schrader et al. (2004) in dormant cambium.

Mazzitelli et al. (2007) observed the presence of ABA-regulated transcripts during dormancy release in raspberry; as also observed by Campbell et al. (2008) in potato tubers, and by Horvath et al. (2008) in leafy spurge. These observations could indicate that ABA is involved in dormancy release by regulating a certain group of genes.

Also ethylene concentration varies during dormancy, as example a peak was detected before the initiation of endodormancy, suggesting this hormone is possibly induced by ABA. Nearly 10 genes associated to ethylene production or ethylene responses are expressed during paradormancy but repressed in endodormancy and ecodormancy (Horvath et al., 2008). Ruttink et al. (2007) also found a certain number of transcripts similar to Arabidopsis genes involved in ethylene signal transduction as ETHYLENE RESPONSIVE FACTOR 4 (AtERF4), AtERF5, AtERF5-LIKE, perception as ETR2 and ERS1 (ETHYLENE RESPONSE SENSOR1), and downstream signalling elements like CONSTITUTIVE TRIPLE RESPONSE1 (CTR1), ETHYLENE INSENSITIVE3 (EIN3), EIN3 BINDING F BOX1 (EBF1) and ETHYLENE-REGULATED NUCLEARLOCALIZED PROTEIN1 (ERN1). Ethylene biosynthesis and signal transduction are simultaneously activated after 2 weeks of SD, just one week before the formation of the terminal bud.

The identification of a high number of genes regulated by jasmonic acid (JA) suggests a possible role of this hormone in dormancy progression. JA is usually associated to wounding and defence mechanisms. During the release of tuber dormancy in potato, the expression of $L O X$ gene coding for a lipoxygenase involved in JA biosynthesis decreases, in addition to other genes involved in tuber development, protein storage and metabolism (Campbell et al. 2008).

\subsubsection{Light perception}

Phytochromes are proteins involved in red/far red light perception and regulate numerous physiological aspects of plant growth mediated by light quality and day length (Fankhauser \& Chory, 1997), as well as circadian clock (Toth et al., 2001).

PHYTOCHROME A (PHYA) is supposed to regulate bud dormancy induction in poplar (Olsen et al., 1997) and aspen (Eriksson et al., 2000). Kim et al. (2002) showed that PHYTOCHROME B (PHYB) was the primary photoreceptor responsible for activation of cold-stress signalling mediated by light. PHYTOCHROME C (PHYC) is up-regulated during the fulfilment of chilling 
requirements and mediates dormancy and germination responses to seasonal cues. PHYC also plays a role in cotyledon expansion in seedlings, and leaf area and stem length increase in adult plant (Mathiason et al., 2009).

The response to blue light involves a rhodopsin receptor whose gene expression decreases early and increases at the end of the chilling period, being interesting as an indicator of chilling requirements (Mathiason et al., 2009).

Horvath et al. (2008) observed that several circadian regulatory genes are surprisingly differentially expressed in crown buds of leafy spurge, that are situated below the soil surface. This is consistent with results in chestnut (Castanea sativa Mill.) showing that CsTOC1 and CsLHY genes with daily cycling expression were constantly and highly expressed during dormancy. The oscillation was recovered when the plant returned to $22^{\circ} \mathrm{C}$. Notably, this phenomenon is not present in Arabidopsis (Ibañez et al., 2008; Ramos et al., 2005).

\subsubsection{Cell cycle, division and growth}

During the transition from para- to endodormancy the vast majority of genes involved in cell proliferation are down-regulated, including cell cycle regulators such as CYCLIN Al (CYCA1), CYCA2, CYCA3, CYCD3 and CYCLIN-DEPENDENT KINASE A1 (CDKA1), CDKB1, CDKB2, CYCH1, as well as RETINOBLASTOMA PROTEIN, DP-E2F-LIKE PROTEIN3 and CKS1 (Ruttink et al., 2007).

On the other side, genes involved in cell cycle, division and growth are induced during the chilling period. In this period cell cycle is re-established and cells start growing. Druart et al. (2007) reported that these genes were down-regulated upon dormancy establishment in aspen and then their expression remained low or slightly increased during ecodormancy. On the contrary, many of the genes involved in cell division are down-regulated during the transition from endodormancy to ecodormancy in leafy spurge (Horvath et al., 2008).

\subsubsection{Transport genes}

Some ATP binding cassette proteins (ABC) have been found down-regulated during the dormant period. Four of these proteins have been found in grape buds (Mathiason et al., 2009), two in leafy spurge crown buds (Horvath et al., 2008), and one in raspberry buds (Mazzitelli et al., 2007). 
During dormancy establishment and release, plant is subjected to high variations in water content for the adjustment of osmotic pressure in cells. Aquaporins belong to a highly conserved group called major intrinsic proteins that control water movement between cells and possibly also modulate the transport of water through membranes to regulate osmotic pressure. This group of proteins is divided in four subfamilies, one of which is plasma membrane intrinsic proteins (PIP). Three of these PIPs were found induced during the period of accumulation in Vitis (Mathiason et al., 2009).

On the other side, water transport is reduced during dormancy induction by blockage of plasmodesmata through differential calcium (Jian et al., 1997) or 1,3 $\beta$-glucan deposition (Rinne et al., 2001; Rinne \& Van der Schoot, 2003). During dormancy release a high expression of 1,3- $\beta$ glucanases, involved in plasmodesmata opening, was detected in peach bark (Bassett et al., 2006) as well as in poplar (Rinne et al., 2011).

Nitrate is a nitrogen source for ammonium and amino acids synthesis, which makes it essential for plant growth and development. During chilling accumulation two nitrate transporters were found up-regulated in Vitis (Mathiason et al., 2008), and one in orange (Poncirus trifoliate) (Zhang et al., 2005). This indicates that buds are preparing for protein production. A role of nitrate as a signal molecule favouring germination has been hypothesized (Alboresi et al., 2005); thus we cannot discard a related signalling function also in buds.

\subsubsection{Regulation of gene expression}

\section{DAM-like transcription factors}

DAM-like genes have been related to dormancy maintenance through sequencing and annotation of the evg mutant and QTLs analysis in peach. The relevance of these transcription factors is highlighted by the abundant literature showing dormancy-dependent regulation of DAM-like genes in other species as poplar (Ruttink et al., 2007; Druart et al., 2004), raspberry (Mazzitelli et al., 2007), Japanese apricot (Yamane et al., 2008), leafy spurge (Horvath et al., 2008), blackcurrant (Hedley et al., 2010) as well as in peach fruit tissue after cold storage (Ogundiwin et al., 2008). The seasonal expression pattern of $D A M$ genes in peach indicates that they are induced at different stages: DAM3,DAM5 and DAM6 during dormancy entrance, and DAM1,DAM2 and DAM4 during terminal bud formation (Li et al., 2009). Recently, Jiménez et al. (2010b) proposed DAM5 and DAM6 as quantitative repressors of bud dormancy release. A transgenic poplar 
expressing constitutively DAM6 showed terminal bud formation and dormancy induction under normal growing conditions, thus confirming this supposed role (Sasaki et al., 2011).

\section{Other transcription factors}

The setting up of dormancy involves the transcriptional regulation of a large number of genes. Thus, the identification of transcription factors with dormancy-dependent gene expression represents an important step in understanding the process.

Schrader et al. (2004) identified in poplar cambium a gene with similarities to the CCAATbinding factor $H A P 2$ from aspen, which is induced during dormancy. This protein is part of a complex that includes the seed dormancy regulator LEC1 (Kwong et al., 2003; Lee et al., 2003). In poplar, Rohde et al. (2007) identified three regulatory genes AP2/EREBP, ERF4 and WRKY11 clearly expressed after 24 days under SD. Based of the function of their respective Arabidopsis homologues, these genes could be involved in ABA and ethylene signal transduction. The ERF4 homologue in Arabidopsis is transcriptionally induced by ethylene, jasmonate, and ABA and acts as a transcriptional repressor capable of modulating ABA and ethylene responses. Overexpression of ERF4 leads to ethylene insensitivity and increases ABA sensitivity. Together, the change in expression of AP2/EREBP, ERF4 and WRKY11 during dormancy induction supports a role in endodormancy set up in apical bud and paradormancy in axillary buds (Rohde et al., 2007).

\section{Chromatin regulation}

FERTILIZATION INDEPENDENT ENDOSPERM (FIE)-like genes are members of the polycomb family of regulators of the chromatin structure that were observed to be strongly up-regulated in poplar cambium and buds during dormancy (Schrader et al., 2004; Ruttink et al., 2007). In Arabidopsis, FIE product acts as part of a complex that silences the transcription of genes necessary for proliferation, through modification of the chromatin structure. Also homologues of the chromatin-remodelling factor PICKLE (PKL), CDC48-LIKE, and HISTONE1-3 are strongly up-regulated in poplar buds after shortening the day-length (Schrader et al., 2004). These findings also reinforce the idea that chromatin remodelling and modification processes are involved in dormancy (Ruttink et al., 2007). 


\section{CBFs}

The best-known regulatory pathway in cold acclimation is the CBF/DREB1 cold response pathway that has been well characterized in Arabidopsis (Nakashima \& Yamaguchi-Shinozaki, 2006). The $C B F$ genes are induced within 15 min of cold exposure, followed by the induction of $C B F$ target genes by its binding to LTRE/DRE/CRT elements in their promoters. Overexpression of $C B F$ leads to increased freezing but also drought and salt tolerance (Jaglo-Ottosen et al., 1998; Kasuga et al., 1999, Gilmour et al., 2000).

$C B F$ orthologues of woody plants are similarly induced by low temperatures during normal growth, in dormant cambium in autumn (Schrader et al., 2004), as well as after SD exposure (Jaglo-Ottonsen et al., 1998), suggesting that they participate in both cold acclimation and freezing tolerance. In order to identify genes under $C B F$ regulation, Benedict et al. (2006) compared the transcriptomes after cold exposure of wild-type poplar and a $C B F$-overexpressing line, concluding that many of these cold-regulated genes were in fact orthologues of genes from the $C B F$ regulon in Arabidopsis (Welling et al., 2006).

\subsection{Transgenic approaches towards the regulation of bud dormancy}

Genes identified by transcriptomic approaches require a deeper functional study that can be achieved by gene introgression into a suitable plant. In classical breeding this is performed by means of repetitive backcrosses, being a long process greatly depending on the length of the reproductive cycle of the plant. A simpler and cleaner alternative is the production of transgenic plants. This technology has been used both for functional studies and introduction of agronomic traits in crops.

Olsen et al. (1997) reported that the overexpression of oat PHYA gene in aspen hybrid (Populus tremula $x$ P. tremuloides) prevented this tree to enter dormancy even when critical day-length was changed from 15 to $6 \mathrm{~h}$. These transgenic plants didn't present leaf abscission, growth cessation, and cold acclimation, as GA and indoleacetic acid (IAA) levels still remained high under SD conditions. A reduced expression of PHYA, on the other side, accelerated bud formation in response to SD (Erikkson et al., 2000).

Also in aspen, the overexpression of PtFT and PtCO induced a continuous growth habit under SD conditions (Böhlenius et al., 2006). Actually, plants engineered with the overexpression of PtFT are used to shorten the juvenility period in woody trees (Lewis \& Kernodle, 2009). 
Poplar overexpressing $A B I 3$, as well as birch with a dominant negative version of ETRI failed to form buds and yet became dormant, suggesting that bud formation and dormancy set up are independent processes (Rohde et al., 2002; Ruonala et al., 2006).

Apple transformed with $C B F$ transcription factor from peach showed higher sensitivity to short day-lenght and an increase to frost tolerance (Wisniewski et al., 2011).

The constitutive expression of the BpMADS4 gene has been shown to induce early flowering in birch (Betula pendula) and apple (Malus x domestica), but not in poplar (Flachowsky et al., 2007). Transgenic trees maintain leaves, growth and the photosynthetic activity during autumn and winter (Hoenicka et al., 2008). This finding open new interesting questions about the differences in dormancy regulatory mechanisms among woody plants.

Plants transformed with DAM6 from Prunus mume and Prunus persica have been obtained respectively in poplar and plum. Transgenic poplars showed growth cessation and terminal bud set under favourable conditions (Sasaki et al., 2011), while transgenic plums showed more branches and were dwarf (Fan, 2010).

The most interesting results obtained in controlling the time of flowering in woody trees, were achieved with the work by Weigel \& Nilsson (1995). With the introgression of PtFT in P.tremula plants flowered within 4 weeks instead of 8-20 years in normal conditions. In citrus, early flowering and fruiting trees were obtained by transformation of Poncirus trifoliata with a citrus orthologue of FT (Endo et al., 2005) and with the Arabidopsis APl gene (Peña et al., 2001). 



\section{MAIN OBJECTIVES}

The general aim of this work is to understand the molecular and physiological mechanisms underlying the maintenance and release of seasonal dormancy in peach. To achieve this goal, successive specific objectives have been accomplished during this four-years work:

- Identification of peach genes related to dormancy release by suppression subtractive hybridization (SSH) and microarray hybridization.

- Evaluation of the identified genes to assess the chilling requirement of cultivars by analysis of expression.

- Study of chromatin modifications associated to dormancy release in the DAM6 gene.

- Analysis of common physiological and molecular features shared by dormancy processes in buds and seeds. 

2. Identification of genes associated with bud dormancy release in Prunus persica by suppression subtractive hybridization

Leida C. Terol J., Martí G., Agustí M., Llácer G., Badenes M.L., Ríos G. 2010. Identification of genes associated with bud dormancy release in Prunus persica by suppression subtractive hybridization. Tree Physiology 30: 655-666. 



\section{Abstract}

To better understand the molecular and physiological mechanisms underlying maintenance and release of seasonal bud dormancy in perennial trees, we identified differentially expressed genes during dormancy progression in reproductive buds from peach (Prunus persica [L.] Batsch) by suppression subtraction hybridization (SSH) and microarray hybridization. Four SSH libraries were constructed, which were respectively enriched in cDNA highly expressed in dormant buds (named $\mathrm{DR}$ ), in dormancy released buds (RD), and in the cultivars with different chilling requirement 'Zincal 5' (ZS) and 'Springlady' (SZ), sampled after dormancy release. About 2,500 clones picked from the four libraries were loaded on a glass microarray. Hybridization of microarrays with the final products of SSH procedure was performed in order to validate the selected clones that were effectively enriched in their respective sample. Nearly 400 positive clones were sequenced, which corresponded to 101 different unigenes with diverse functional annotation. We obtained DAM4, 5, and 6 genes coding for MADS-box transcription factors previously related to growth cessation and terminal bud formation in the evergrowing mutant of peach. Several other cDNAs are similar to dormancy factors described in other species and others have been related to bud dormancy for the first time in this study. Quantitative RT-PCR analysis confirmed differential expression of cDNAs coding for a Zn-finger transcription factor, a GRAS-like regulator, a DNA binding protein, and proteins similar to forisome subunits involved in the reversible occlusion of sieve elements in Fabaceae, among others.

\section{Introduction}

Perennial woody plants from temperate regions, such as peach species (Prunus persica [L.] Batsch), cease growth and become dormant during part of autumn and winter to elude the detrimental effect of the exposure to low temperatures. This state has been designated endodormancy because bud growth inhibition is due to signals internal to the bud itself, in contrast to bud growth inhibition by other distal organs (paradormancy), or by environmental factors (ecodormancy). For the purpose of this work, the term dormancy has been employed to refer to the endodormant state. The physiological and genetic control of bud dormancy has been reviewed by different authors (Arora et al., 2003; Horvath et al., 2003; Rohde \& Bhalerao, 2007; Allona et al., 2008). In summary, these reviews emphasize the relevant role of day-length shortening, temperature, abscisic acid (ABA), ethylene and gibberellins (GA) as signals affecting bud set and dormancy onset, and discuss some molecular mechanisms related to the process, including cell cycle regulation, modification of the cell water status, and epigenetic regulation. Releasing of bud dormancy requires the completion of a 
chilling period that leaves the bud in an ecodormant state, susceptible to initiate budbreak after a period of favourable temperatures. The length and intensity of this chilling requirement depend on the species and cultivar under study, suggesting genetic control of this process.

The identification of non-dormant mutants in hazelnut (Thompson et al., 1985) and the evergrowing mutant in peach showing defective terminal bud formation (Rodríguez et al., 1994) offered genetic tools to dissect the molecular control of bud dormancy. Recently, a genomic deletion has been identified in the mutant evergrowing that affects several members of a six tandemly repeated series of related MADS box genes (DAM1-6, for DORMANCY-ASSOCIATED MADS-BOX) in tight linkage to the observed phenotype (Bielenberg et al., 2008). Thus DAM genes are considered major candidates to control bud dormancy and meristem growth cessation through regulation of gene expression. However dormancy release is a complex trait that most likely involves numerous genes. In order to identify dormancy-related genes and to elucidate the molecular mechanisms underlying bud set and break in different species, several authors used distinct methodological approaches involving studies of gene transcription as cDNA microarray profiling (Schrader et al., 2004; Druart et al., 2007; Mazzitelli et al., 2007; Ruttink et al., 2007; Horvath et al., 2008; Mathiason et al., 2009), cDNA-AFLP (Rohde et al., 2007) and suppression subtraction hybridization (SSH, Jia et al., 2006; Xin et al., 2008; Yamane et al., 2008).

In this paper we describe the results of a transcriptomic approach for the isolation of cDNA fragments differentially transcribed during the fulfillment of the chilling requirement in peach flower buds. In order to achieve this goal, we first estimated the approximate dormancy-release date of the peach varieties 'Zincal 5' and 'Springlady' by measuring the mean time to budbreak (MTB). An RNA sample from 'Springlady' buds (medium chilling requirement) collected just after dormancy release was then compared in a first experiment against RNA from dormant buds of 'Springlady', and in a second experiment against RNA from dormancy released buds of 'Zincal 5' (low chilling). Thus we expected to identify genes regulated during dormancy progression and release in flower buds (first experiment) and other genes whose expression is due to or causing genotype-dependent differences in chilling requirement for dormancy release (second experiment). We employed the SSH procedure to perform both RNA comparisons (Diatchenko et al., 1996), which relies on the selective amplification and enrichment of abundant cDNAs in a sample (tester) when incubated and hybridized with an excess of a reference sample (driver). After hybridization of two sets of cDNA to be compared, an adaptor-based PCR approach allows subtraction of common cDNAs and amplification of rare and differentially expressed cDNAs. In addition to genes 
previously associated with dormancy processes (ie. DAM genes), other genes not previously related to the dormancy process are described in this work, some of them identified for the first time in peach.

\section{Materials and methods}

\section{Plant material}

The peach cultivars 'Zincal 5' and 'Springlady' were employed in this study. The two orchards were located in the vicinity of Valencia (Spain). The samples required for the SSH procedure were obtained from flower buds of 'Springlady' collected on 14 November 2007 (dormant buds) and 8 January 2008 (dormancy released buds), and flower buds of 'Zincal 5' collected on 18 December 2007 (dormancy released buds). Daily average temperatures in the orchards under study were $11.4^{\circ} \mathrm{C}$ on 14 November $2007,8.7^{\circ} \mathrm{C}$ on 8 January 2008 and $7.3^{\circ} \mathrm{C}$ on 18 December 2007. No rainfall was recorded on these days. Budbreak measurements were performed on flower buds collected at different times from November 2007 until February 2008, whereas buds for RT-PCR analysis were collected from October 2008 until February 2009. Buds were routinely pooled from shoots obtained from different trees.

\section{Budbreak measurements}

$\mathrm{CO}_{2}$ release was measured on excised flower buds introduced into a hermetic jar for 3-4 hours at $20^{\circ} \mathrm{C}$. Four $1-\mathrm{ml}$ aliquots of the internal atmosphere were withdraw with a hypodermic syringe and injected into a gas chromatograph (Perkin Elmer Autosample). Carbon dioxide concentration was analysed by a thermal conductivity detector coupled to a Chromosorb column at $60{ }^{\circ} \mathrm{C}$. Single bud weight was calculated after weighing a pool of 100 reproductive buds and dividing the value by 100.

The mean time to budbreak (MTB) was calculated as described in Gariglio et al. (2006). Briefly, 20 shoots from the different cultivars at different times were placed with their basal tip in water and forced in a phytotron at 8 -hour photoperiod $\left(22.5 \mu \mathrm{mol} /\left(\mathrm{m}^{2} \mathrm{~s}\right)\right)$ at $20{ }^{\circ} \mathrm{C}$ during 6 weeks. The shoots were divided in four groups of five shoots each. The basal ends of the shoots were cut weekly and water was replaced daily. The number of opening buds was recorded three times per week. Time to budbreak of a group of shoots was the time in days required to open at least $50 \%$ of the flower buds. The results were expressed as the arithmetic mean of the time to budbreak for the four groups. 


\section{Isolation of RNA and $m R N A$ purification}

Total RNA was isolated from 0.5-2 g of flower buds (about 50-200 buds) by a guanidine thiocyanate-based protocol applied to high phenolic content tissues (Salzman et al., 1999). Poly A ${ }^{+}$ RNA was subsequently purified by using the Oligotex ${ }^{\circledR}$ mRNA Purification System (Qiagen) according to the manufacturer's instructions. The mRNA concentration in the solution was measured with the Quant-iT ${ }^{\mathrm{TM}}$ RiboGreen ${ }^{\circledR}$ RNA Assay Kit (Invitrogen). The poly $\mathrm{A}^{+}$RNA was concentrated by precipitation with two volumes of ethanol (overnight at $-20{ }^{\circ} \mathrm{C}$ ), in the presence of $33 \mathrm{mM} \mathrm{NaCl}$ and GlycoBlue ${ }^{\mathrm{TM}}$ Coprecipitant (Ambion), and then washed with ethanol $80 \%$. The poly $\mathrm{A}^{+}$RNA was subsequently dissolved in RNAse free water at a concentration of $33 \mathrm{ng} / \mu \mathrm{l}$.

\section{SSH analysis}

SSH was performed according to Diatchenko et al. (1996) with tester and driver cDNAs as shown in Table 1. Briefly, About $100 \mathrm{ng}$ of poly $\mathrm{A}^{+}$RNA isolated from those samples as shown above was reverse transcribed to cDNA using the SMART ${ }^{\mathrm{TM}}$ PCR cDNA Synthesis Kit (Clontech). The resulting cDNA was digested with $R s a \mathrm{I}$ and purified using the High Pure PCR Product Purification Kit (Roche). Subtraction was performed with the PCR-Select ${ }^{\mathrm{TM}}$ cDNA Subtraction Kit (Clontech) according to manufacturer's manual. The SSH products were purified using the High Pure PCR Product Purification Kit (Roche). Subtracted cDNAs were ligated into the pGEM®-T-Easy vector (Promega) and cloned into JM109 Escherichia coli cells. After growing on plates containing ampicillin, isopropyl-D-thiogalactopyranoside (IPTG) and 5-bromo-4-cloro-3-indolil- $\beta$-Dgalactopiranósido (X-gal), white colonies were picked and incubated overnight at $37{ }^{\circ} \mathrm{C}$ into 96 well plates containing ampicillin. Sterile glycerol was added to a final concentration of $20 \%$ for stable storage of cultures at $-80^{\circ} \mathrm{C}$. The DR and RD libraries were respectively enriched in cDNA abundant in dormant and dormancy released buds from 'Springlady', whereas ZS and SZ libraries were enriched in transcripts from dormancy released buds of 'Zincal 5' and 'Springlady' respectively.

\section{Microarray preparation and hybridization}

The cloned cDNAs were directly amplified from $E$ coli cultures. About $5 \mu$ l of stored cultures were

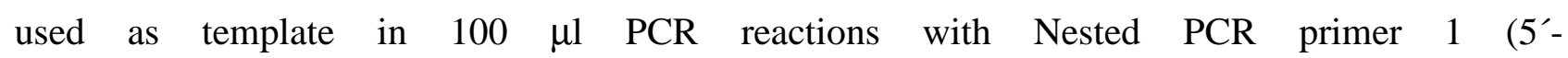
TCGAGCGGCCGCCCGGGCAGGT-3') and Nested PCR primer 2R (5'- 
AGCGTGGTCGCGGCCGAGGT-3') by following these conditions: $94{ }^{\circ} \mathrm{C}$ for $5 \mathrm{~min}$, then 35 cycles of $94{ }^{\circ} \mathrm{C}$ for $30 \mathrm{~s}, 68{ }^{\circ} \mathrm{C}$ for $30 \mathrm{~s}, 72^{\circ} \mathrm{C}$ for $2 \mathrm{~min}$, and a final extension of $72{ }^{\circ} \mathrm{C}$ for $5 \mathrm{~min}$. Quality and success of the amplification was confirmed by agarose gel electrophoresis. PCR products were purified using the Multiscreen ${ }^{\circledR}$ PCR $\mu 96$ Filtration System (Millipore), and resuspended in water to a final concentration of $200-400 \mathrm{ng} / \mu \mathrm{l}$. Before printing, purified PCR fragments were transferred to 384-well low volume, low profile plates (Corning) at a final concentration of 100-200 ng/ $\mu \mathrm{l}$ in 50\% dimethylsulphoxide. Each clone was spotted twice. Samples were spotted on Corning UltraGAPS glass slides, using a MicroGrid II spotting device from Biorobotics, in a 16-block format and 12 by 14 spots per block. Slides were crosslinked at $150 \mathrm{~mJ}$ and stored. Microarray hybridization was performed as previously described (Ríos et al., 2008). The SSH final products were labelled with the BioPrime® Plus Array CGH Genomic Labeling System (Invitrogen) according to manufacturer's instructions. About 500 ng of each sample was labelled with both, Alexa Fluor ${ }^{\circledR} 555$ and Alexa Fluor ${ }^{\circledR} 647$ fluorescent dyes. Data analysis was performed using the Limma package from the R statistical computing software (Gentleman et al., 2004). The $P$-value to control the false discovery rate was adjusted with the Benjamini and Hochberg's method. Each comparison of a pair of SSH products required four independent hybridizations with dye swap.

\section{Sequence data analysis}

Clones showing a $P$-value higher than 0.05 in the microarray analysis were not further considered. For sequencing purposes, we gave preference to clones that had at least a two-fold signal difference between SSH samples in both microarray comparisons or at least a four-fold signal difference in one of the comparisons. Only microarray-validated clones that consistently produced strong single bands following amplification and digestion with RsaI were sequenced. Base calling, trimming of low quality regions and vector masking were performed with phred and Crossmatch (Ewing \& Green, 1998). Reading assembly was performed with the CAP3 (Huang \& Madan, 1999). Similarity searches were performed with the standalone version of BLAST (Altschul et al., 1990), against the NCBI non-redundant protein database, using an e-value cutoff of $10^{-7}$. Parsing of the BLAST results was performed with the Bio::SearchIO module from the Bioperl package (Stajich et al., 2002). Gene Ontology and functional annotations was performed with BLAST2GO (Conesa et al., 2005). 


\section{Real time RT-PCR}

Extraction of RNA from reproductive buds at different developmental stages, poly $\mathrm{A}^{+} \mathrm{RNA}$ purification and quantification were performed as described above. About $80 \mathrm{ng}$ of poly $\mathrm{A}^{+} \mathrm{RNA}$ were reverse transcribed with the SuperScript III First-Strand Synthesis System for RT-PCR (Invitrogen) in a total volume of $20 \mu \mathrm{l}$. One $\mu \mathrm{l}$ of a ten times diluted first-strand cDNA was used for each amplification reaction in a final volume of $20 \mu \mathrm{l}$. Quantitative real-time PCR was performed on a StepOnePlus ${ }^{\mathrm{TM}}$ Real-Time PCR System (Applied Biosystems), using the Power SYBR ${ }^{\circledR}$ Green PCR Master Mix (Applied Biosystems). Reaction composition and conditions followed manufacturer's instructions. The primers employed are listed in Supplementary Figure 2. Cycling protocol consisted of $10 \mathrm{~min}$ at $95^{\circ} \mathrm{C}$, then 40 cycles of $15 \mathrm{sec}$ at $95^{\circ} \mathrm{C}$ for denaturation, and $60 \mathrm{sec}$ at $60^{\circ} \mathrm{C}$ for annealing and extension. Specificity of the PCR reaction was assessed by the presence of a single peak in the dissociation curve after the amplification and through size estimation of the amplified product. The comparative $\mathrm{C}_{\mathrm{T}}\left(\Delta \Delta \mathrm{C}_{\mathrm{T}}\right)$ method was used to quantify those cDNAs with amplification efficiencies equivalent to the reference Actin gene. PpB20 amplicon, showing different amplification efficiency, was quantified by performing relative standard curves. Results were the average of 2 independent biological replicates repeated twice. 


\section{Results}

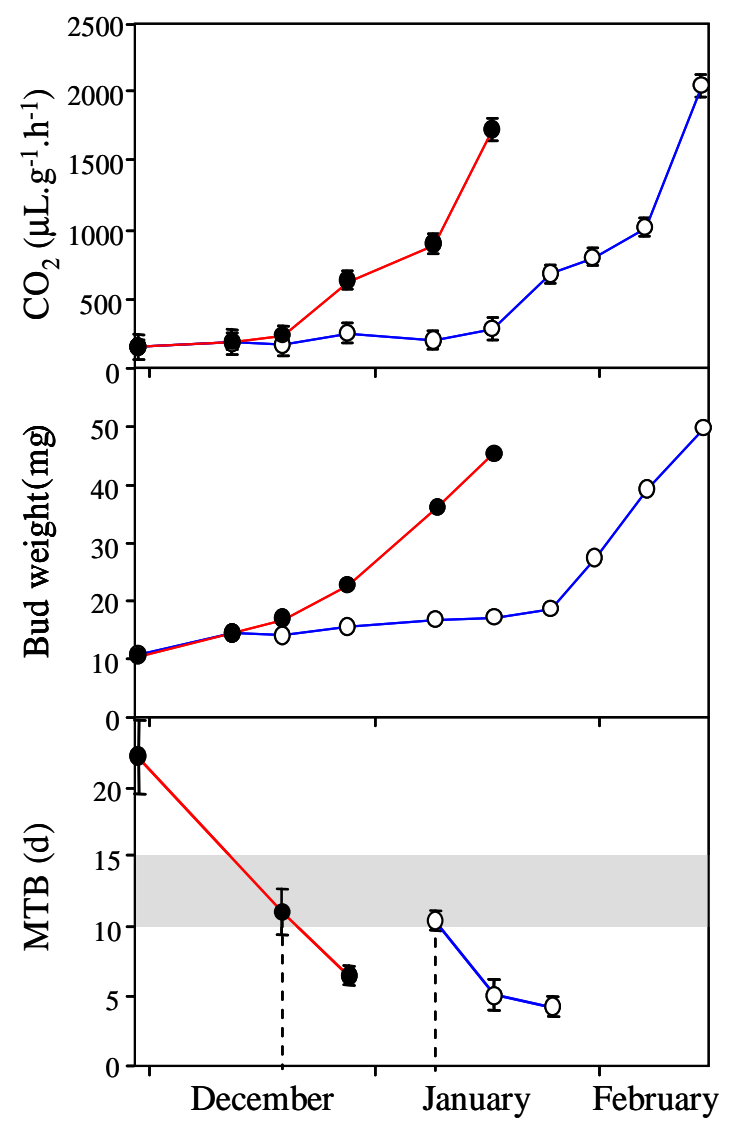

Figure 2.1. Flower bud parameters in 'Springlady' and 'Zincal 5' cultivars. The $\mathrm{CO}_{2}$ release, weight and MTB of 'Springlady' (blue line-empty circles) and 'Zincal 5' (red line-filled circles) buds were recorded during autumn and winter seasons of years 2007-2008. The MTB interval from 10 to 15 days is shaded. Dashed lines label the genotype-specific dormancy release dates. Error bars represent standard deviations.

\section{Two peach genotypes showing different chilling requirements}

A genomic approach to the identification of genes and pathways involved in release of seasonal dormancy in peach requires a previous physiological assessment of the varieties under study. Dormancy release is conditioned by the fulfilment of the genotype-specific chilling requirement and other internal factors, which leave buds in an ecodormant state. Budbreak is subsequently happening after ecodormancy release under favourable environmental conditions. Whereas time to budbreak can be estimated by detecting the $\mathrm{CO}_{2}$ produced by cell respiration in the bud and also by measuring the increase of bud weight due to the initiation of meristem growth, dormancy release time has to be measured by indirect means excluding environmental effects. This was accomplished by calculating the mean time to budbreak (MTB) of flower buds from shoots cut at different times and incubated under forcing conditions as shown in Materials and Methods. Those parameters were measured at different times during autumn and winter of years 2007-2008 in the cultivars under study 'Springlady' and 'Zincal 5'. 
The burst in $\mathrm{CO}_{2}$ release and increase in bud weight occurred in 'Zincal 5' about one month earlier than in 'Springlady' (Figure 2.1), indicating distinct requirements for bud metabolic activation and growth initiation in both cultivars. However their different chilling needs for dormancy release could only be estimated by MTB assessment. Since budbreak has a stochastic component, we decided to limit the MTB for dormancy release to an interval of 10-15 days, based on physiological works showing that MTB is usually stabilized in this time interval after dormancy releasing (Gariglio et al., 2006). Following this criterion 'Zincal 5' was three weeks earlier than 'Springlady', with release dates 18 December and 8 January respectively (Figure 2.1). Interestingly, 'Zincal 5' but not 'Springlady' was able to budbreak to some extent before its dormancy release date. As generally accepted, the length of the chilling period required for dormancy release is a more reliable and comparable measurement of the dormant behaviour of different peach cultivars than simple dates. Thus, by defining a chilling hour $(\mathrm{CH})$ as one-hour interval at $7{ }^{\circ} \mathrm{C}$ or lower temperature (Weinberger 1950), we estimated a chilling requirement of $330 \mathrm{CH}$ for 'Zincal 5' and $430 \mathrm{CH}$ for 'Springlady' under our field conditions.

\section{SSH analysis}

As stated above, $\mathrm{SSH}$ is a widely used approach to isolate differentially expressed genes in two related samples. We designed a double SSH experiment to characterize the time and genotype dependent regulation of the peach bud transcriptome during seasonal dormancy. In the first experiment, cDNA samples from reciprocally subtracted libraries of dormant buds and dormancyreleased buds of 'Springlady' were generated, which were respectively named DR and RD (Table 1). In the second experiment, reciprocal libraries from the cultivars 'Zincal 5' and 'Springlady' after bud dormancy release were produced (respectively ZS and SZ). A total of 2496 clones of putative differentially-expressed genes were isolated from the four libraries, with an insert size ranging from 200 to 1500 bp (not shown). Glass microarrays were constructed containing the amplified and purified inserts of these 2496 clones. 
Table 2.1. SSH libraries elaborated in this work.

\begin{tabular}{|c|c|c|c|c|c|}
\hline \multirow{2}{*}{$\begin{array}{l}\text { SSH } \\
\text { library }\end{array}$} & \multirow[t]{2}{*}{ Tester } & \multirow[t]{2}{*}{ Driver } & \multirow[t]{2}{*}{ Clones } & \multicolumn{2}{|c|}{$\begin{array}{c}\text { Percentage of microarray- } \\
\text { validated clones }\end{array}$} \\
\hline & & & & $\mathrm{M}=1^{(*)}$ & $\mathrm{M}=2^{(*)}$ \\
\hline DR & $\begin{array}{l}\text { Dormant buds from } \\
\text { 'Springlady' }\end{array}$ & $\begin{array}{l}\text { Dormancy released buds } \\
\text { from 'Springlady' }\end{array}$ & 768 & $35 \%$ & $7 \%$ \\
\hline $\mathrm{RD}$ & $\begin{array}{l}\text { Dormancy released buds } \\
\text { from 'Springlady' }\end{array}$ & $\begin{array}{l}\text { Dormant buds from } \\
\text { 'Springlady' }\end{array}$ & 768 & $48 \%$ & $24 \%$ \\
\hline $\mathrm{ZS}$ & $\begin{array}{l}\text { Dormancy released buds } \\
\text { from 'Zincal 5' }\end{array}$ & $\begin{array}{l}\text { Dormancy released buds } \\
\text { from 'Springlady' }\end{array}$ & 480 & $15 \%$ & $3 \%$ \\
\hline $\mathrm{SZ}$ & $\begin{array}{l}\text { Dormancy released buds } \\
\text { from 'Springlady' }\end{array}$ & $\begin{array}{l}\text { Dormancy released buds } \\
\text { from 'Zincal 5' }\end{array}$ & 480 & $21 \%$ & $9 \%$ \\
\hline
\end{tabular}

(*) M value is $\log 2$-signal ratio.

In order to validate those clones effectively enriched in any of the four libraries, the final products of the four SSH experiments containing cDNAs accumulated under different conditions were labelled with fluorescent dyes, combined in pairs (DR against RD and ZS against SZ), and hybridized to the microarray as described in Material and Methods. With the exception of the RD library with $24 \%$, the rest of the libraries had less than $10 \%$ of their respective clones differentially accumulated at levels greater than 4 fold ( $\log 2$ signal ratio $>2$; Table 2.1). A total of 364 clones showing 4 fold differences in cDNA accumulation for either the DR/RD or ZS/SZ comparisons, and those having 2 fold differences for both DR/RD and ZS/SZ comparisons were selected and produced suitable sequence data (Supplementary Figure 2.1). A search for coincident clones, as described in Materials and Methods, found 101 unigenes represented by 47 contigs and 54 singletons (Tables 2.2, 2.3 and 2.4). Forty-seven of the 101 unigenes were enriched in the RD sample, 46 in DR, 38 in ZS and 31 in SZ. It was expected to find many of the unigenes enriched in two independent SSH samples, as one of the operational criteria to sequence an EST was to have a threshold value of two fold differential cDNA accumulation in both DR/RD and ZS/SZ comparisons, but interestingly, an Euler diagram of overlapping groups showed a bias towards the coincidence of RD with ZS (29 unigenes) and DR with SZ groups (21 unigenes) (Figure 2.2).

About $50 \%$ of the unigenes were not found in a Blastn search against peach EST databases in the National Center for Biotechnology Information (http://www.ncbi.nlm.nih.gov/), arguing for a relevant number of novel ESTs. Of the 51 ESTs with significant similarity to previously described ESTs, $9(18 \%)$ have been identified in a SSH approach to isolate low temperature and photoperiod regulated genes in bark (Bassett et al., 2006), whereas $24(47 \%)$ have been recently described in an 
article developing genomic tools for the identification of cold-responsive genes from peach fruit mesocarp (Ogundiwin et al., 2008; Tables 2.2, 2.3 and 2.4).

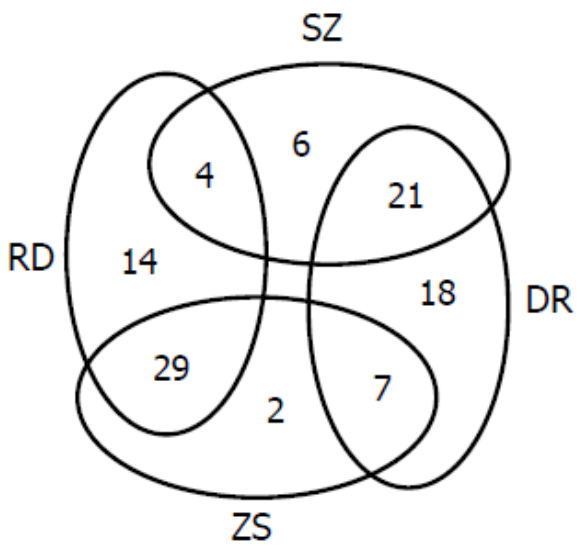

Figure 2.2. Euler diagram with overlapping unigenes. The diagram consists of four ellipses representing unigenes enriched in the dormancy released bud SSH sample (RD), unigenes enriched in the dormant bud sample (DR), unigenes enriched in the 'Zincal 5' sample (ZS), and unigenes enriched in the 'Springlady' sample (SZ). The number of shared unigenes is located in the overlapping sections.

\section{Functional classification of unigenes}

Tables 2.2, 2.3 and 2.4 contain the annotation and functional classification of unigenes based on Blastx best hits. These tables list separately the sequences enriched in the dormant sample DR (Table 2.2), in the dormancy-released sample RD (Table 2.3), and those that accumulated in ZS or SZ samples but not in DR or RD (Table 2.4). Unigenes representing very diverse biochemical, cellular and molecular functions were classified into six major categories: Metabolism, oxidationreduction, stress and defence, signalling and transcription, transport and other. This last category (other) included also unigenes coding for proteins with unknown function or with no similarity in databases. From the 101 studied unigenes, only 13 corresponding to 54 clones did not show any Blastx hit at an E-value cut-off of $10^{-7}$. The most remarkable case in this group is PpB94 containing 22 ESTs in the SZ group of 'Springlady' enriched transcripts. Some of the most striking observations arising from these lists were the high number of peroxidase ESTs found in the RD fraction (77) and the abundant number of transcription factors present in the DR and SZ groups (Tables 2.2 and 2.3). 
Table 2.3 List of unigenes enriched in the dormacy-released sample (RD).

\begin{tabular}{|c|c|c|c|c|c|}
\hline Unigenes & $\begin{array}{l}\text { Expression } \\
\text { group }\end{array}$ & EST & Blastx hit & $\begin{array}{c}\text { Blastx } \\
\text { E-value }\end{array}$ & $\begin{array}{c}\text { Previous } \\
\text { works }\end{array}$ \\
\hline \multicolumn{6}{|c|}{ Metabolism } \\
\hline PpB47 & $\mathrm{RD} / \mathrm{ZS}$ & 13 & acyl:coa ligase [Populus trichocarpa] & $1 \times 10^{-135}$ & \\
\hline PpB48 & $\mathrm{RD}$ & 6 & putative strictosidine synthase [Arabidopsis thaliana] & $1 \times 10^{-96}$ & \\
\hline PpB49 & $\mathrm{RD} / \mathrm{ZS}$ & 6 & strictosidine synthase family protein [Brassica napus] & $4 \times 10^{-56}$ & \\
\hline PpB50 & $\mathrm{RD}$ & 5 & acyl:coa ligase [Populus trichocarpa] & $3 \times 10^{-48}$ & \\
\hline PpB51 & $\mathrm{RD}$ & 5 & chs-like protein [Populus trichocarpa] & $4 \times 10^{-79}$ & \\
\hline PpB52 & $\mathrm{RD}$ & 3 & Carboxyl-terminal peptidase, putative, expressed [Oryza sativa] & $2 \times 10^{-42}$ & \\
\hline PpB53 & $\mathrm{RD} / \mathrm{ZS}$ & 3 & dihydroflavonol 4-reductase, putative [Arabidopsis thaliana] & $3 \times 10^{-102}$ & \\
\hline PpB54 & $\mathrm{RD}$ & 2 & carboxyl-terminal proteinase [Zea mays] & $1 \times 10^{-39}$ & \\
\hline PpB55 & $\mathrm{RD} / \mathrm{ZS}$ & 2 & dihydroflavonol 4-reductase family [Arabidopsis thaliana] & $2 \times 10^{-37}$ & \\
\hline PpB56 & $\mathrm{RD}$ & 1 & dihydroflavonol 4-reductase family [Arabidopsis thaliana] & $3 \times 10^{-36}$ & \\
\hline PpB57 & $\mathrm{RD}$ & 1 & chalcone synthase family protein [Arabidopsis halleri subsp. gemmifera] & $8 \times 10^{-37}$ & \\
\hline PpB58 & $\mathrm{RD}$ & 1 & similar to putative polyubiquitin (UBQ10) [Vitis vinifera] & $2 \times 10^{-26}$ & \\
\hline PpB59 & $\mathrm{RD} / \mathrm{SZ}$ & 1 & xyloglucan endotransglucosylase/hydrolase 5 [Malus $x$ domestica $]$ & $2 \times 10^{-127}$ & \\
\hline PpB60 & $\mathrm{RD} / \mathrm{ZS}$ & 1 & glucose-methanol-choline (gmc) oxidoreductase, putative [Ricinus communis] & $1 \times 10^{-64}$ & \\
\hline PpB61 & $\mathrm{RD} / \mathrm{ZS}$ & 1 & acyl:coa ligase $[$ Populus trichocarpa $]$ & $6 \times 10^{-22}$ & \\
\hline PpB62 & $\mathrm{RD} / \mathrm{ZS}$ & 1 & flavonoid 3-hydroxylase, putative [Ricinus communis] & $7 \times 10^{-132}$ & \\
\hline \multicolumn{6}{|c|}{ Oxidation-reduction } \\
\hline PpB63 & $\mathrm{RD}$ & 41 & Peroxidase 40 precursor, putative [Ricinus communis] & $8 \times 10^{-121}$ & \\
\hline PpB64 & $\mathrm{RD} / \mathrm{ZS}$ & 22 & Peroxidase 9 precursor, putative [Ricinus communis] & $1 \times 10^{-47}$ & 1,2 \\
\hline PpB65 & $\mathrm{RD}$ & 13 & Peroxidase 9 precursor, putative [Ricinus communis] & $2 \times 10^{-48}$ & \\
\hline PpB66 & $\mathrm{RD}$ & 2 & alcohol dehydrogenase (ATA1) [Arabidopsis thaliana] & $5 \times 10^{-83}$ & \\
\hline PpB67 & $\mathrm{RD}$ & 1 & Peroxidase 9 precursor, putative [Ricinus communis] & $1 \times 10^{-15}$ & 1 \\
\hline PpB68 & $\mathrm{RD} / \mathrm{ZS}$ & 1 & Cucumber peeling cupredoxin, putative [Ricinus communis] & $8 \times 10^{-16}$ & \\
\hline \multicolumn{6}{|c|}{ Stress and defence } \\
\hline PpB69 & $\mathrm{RD} / \mathrm{ZS}$ & 4 & dehydration-responsive protein RD22 [Prunus persica] & $4 \times 10^{-81}$ & \\
\hline PpB70 & $\mathrm{RD} / \mathrm{ZS}$ & 1 & RD22-like protein $[$ Vitis vinifera $]$ & $2 \times 10^{-37}$ & \\
\hline \multicolumn{6}{|c|}{ Signalling and transcription } \\
\hline PpB71 & $\mathrm{RD} / \mathrm{ZS}$ & 3 & DNA binding protein, putative [Ricinus communis] & $6 \times 10^{-88}$ & \\
\hline PpB72 & $\mathrm{RD}$ & 1 & Transcription factor ICE1, putative [Ricinus communis] & $2 \times 10^{-10}$ & \\
\hline PpB73 & $\mathrm{RD} / \mathrm{ZS}$ & 1 & DNA binding protein, putative [Ricinus communis] & $1 \times 10^{-51}$ & \\
\hline \multicolumn{6}{|c|}{ Transport } \\
\hline PpB74 & $\mathrm{RD} / \mathrm{ZS}$ & 50 & MEN-8 protein precursor, putative [Ricinus communis] & $2 \times 10^{-18}$ & \\
\hline PpB75 & $\mathrm{RD} / \mathrm{ZS}$ & 3 & lipid binding protein, putative [Ricinus communis] & $9 \times 10^{-25}$ & \\
\hline \multicolumn{6}{|l|}{ Other } \\
\hline $\mathrm{PpB} 76$ & $\mathrm{RD} / \mathrm{ZS}$ & 4 & AAA ATPase containing von Willebrand factor type A [Zea mays] & $1 \times 10^{-10}$ & \\
\hline PpB77 & $\mathrm{RD} / \mathrm{SZ}$ & 3 & tubulin alpha chain, putative [Ricinus communis] & $1 \times 10^{-158}$ & 1 \\
\hline PpB78 & $\mathrm{RD} / \mathrm{ZS}$ & 3 & chlorophyll A/B binding protein, putative [Ricinus communis] & $5 \times 10^{-84}$ & \\
\hline PpB79 & $\mathrm{RD} / \mathrm{ZS}$ & 3 & Rhicadhesin receptor precursor, putative [Ricinus communis] & $4 \times 10^{-70}$ & \\
\hline PpB80 & $\mathrm{RD} / \mathrm{ZS}$ & 2 & conserved hypothetical protein [Ricinus communis] & $2 \times 10^{-33}$ & \\
\hline PpB81 & $\mathrm{RD} / \mathrm{SZ}$ & 1 & early nodulin 93 protein [Populus alba $\times$ Populus tremula var. glandulosa] & $2 \times 10^{-27}$ & \\
\hline PpB82 & $\mathrm{RD} / \mathrm{ZS}$ & 1 & predicted protein [Populus trichocarpa $]$ & $9 \times 10^{-68}$ & \\
\hline PpB83 & $\mathrm{RD} / \mathrm{ZS}$ & 1 & MtN3 [Medicago truncatula] & $1 \times 10^{-76}$ & 1 \\
\hline PpB84 & $\mathrm{RD} / \mathrm{ZS}$ & 1 & conserved hypothetical protein [Ricinus communis] & $3 \times 10^{-24}$ & \\
\hline PpB85 & $\mathrm{RD} / \mathrm{ZS}$ & 1 & Blue copper protein precursor, putative [Ricinus communis] & $2 \times 10^{-42}$ & \\
\hline PpB86 & $\mathrm{RD} / \mathrm{ZS}$ & 1 & mazG nucleotide pyrophosphohydrolase domain protein [Zea mays] & $5 \times 10^{-39}$ & \\
\hline PpB87 & $\mathrm{RD} / \mathrm{ZS}$ & 9 & & & \\
\hline PpB88 & $\mathrm{RD} / \mathrm{ZS}$ & 3 & & & \\
\hline PpB89 & $\mathrm{RD} / \mathrm{ZS}$ & 2 & & & \\
\hline PpB90 & $\mathrm{RD}$ & 1 & & & \\
\hline PpB91 & $\mathrm{RD} / \mathrm{SZ}$ & 1 & & & \\
\hline PpB92 & $\mathrm{RD} / \mathrm{ZS}$ & 1 & & & 1,2 \\
\hline PpB93 & $\mathrm{RD} / \mathrm{ZS}$ & 1 & & & \\
\hline
\end{tabular}

The number of ESTs corresponding to each unigene and the Blastx best hit found in the non-redundant protein database from the National Center for Biotechnology Information (NCBI) are shown. ESTs described in previous works are labelled with 1 (Ogundiwin et al., 2008) or 2 (Bassett et al., 2006). 
Table 2.2 List of unigenes enriched in the dormant bud sample (DR).

\begin{tabular}{|c|c|c|c|c|c|}
\hline Unigenes & $\begin{array}{c}\text { Expression } \\
\text { group }\end{array}$ & EST & Blastx hit & $\begin{array}{c}\text { Blastx } \\
\text { E-value }\end{array}$ & $\begin{array}{c}\text { Previous } \\
\text { works }\end{array}$ \\
\hline \multicolumn{6}{|c|}{ Metabolism } \\
\hline PpB1 & DR & 4 & UDP-galactose 4-epimerase [Cyamopsis tetragonoloba] & $3 \times 10^{-35}$ & 1 \\
\hline $\mathrm{PpB} 2$ & DR & 2 & UDP-glucosyltransferase, putative [Ricinus communis] & $9 \times 10^{-67}$ & \\
\hline PpB3 & DR & 1 & Glucan endo-1,3-beta-glucosidase precursor, putative [Ricinus communis] & $2 \times 10^{-146}$ & \\
\hline PpB4 & $\mathrm{DR} / \mathrm{SZ}$ & 1 & (R)-limonene synthase, putative [Ricinus communis] & $2 \times 10^{-38}$ & \\
\hline PpB5 & $\mathrm{DR} / \mathrm{SZ}$ & 1 & S-like ribonuclease [Prunus dulcis] & $1 \times 10^{-113}$ & \\
\hline \multicolumn{6}{|c|}{ Oxidation-reduction } \\
\hline PpB6 & $\mathrm{DR} / \mathrm{SZ}$ & 1 & cytochrome $\mathrm{P} 450$, putative [Ricinus communis] & $2 \times 10^{-102}$ & \\
\hline PpB7 & $\mathrm{DR} / \mathrm{SZ}$ & 1 & cytochrome P450 [Populus trichocarpa $]$ & $4 \times 10^{-55}$ & 1 \\
\hline \multicolumn{6}{|c|}{ Stress and defence } \\
\hline PpB8 & DR & 7 & multidrug resistance pump, putative [Ricinus comтипis] & $5 \times 10^{-34}$ & \\
\hline PpB9 & DR & 4 & late embryogenesis abundant, putative [Ricinus communis] & $8 \times 10^{-08}$ & 1 \\
\hline PpB10 & $\mathrm{DR} / \mathrm{SZ}$ & 3 & Indole-3-acetic acid-induced protein ARG2, putative [Ricinus communis] & $1 \times 10^{-15}$ & 1,2 \\
\hline PpB11 & $\mathrm{DR} / \mathrm{ZS}$ & 3 & type II SK2 dehydrin [Prunus persica] & $2 \times 10^{-65}$ & 1,2 \\
\hline PpB12 & DR & 2 & multidrug resistance pump, putative [Ricinus communis] & $5 \times 10^{-104}$ & \\
\hline PpB13 & DR & 1 & allene oxide cyclase [Pisum sativum] & $1 \times 10^{-36}$ & \\
\hline PpB14 & DR & 1 & S-adenosylmethionine decarboxylase [Malus $x$ domestica] & $1 \times 10^{-119}$ & 1 \\
\hline $\mathrm{PpB} 15$ & $\mathrm{DR} / \mathrm{ZS}$ & 1 & heat shock protein, putative [Ricinus communis] & $1 \times 10^{-97}$ & \\
\hline \multicolumn{6}{|c|}{ Signalling and transcription } \\
\hline PpB16 & $\mathrm{DR} / \mathrm{SZ}$ & 4 & dam5 [Prunus persica] & $3 \times 10^{-36}$ & \\
\hline PpB17 & $\mathrm{DR} / \mathrm{SZ}$ & 3 & dam6 [Prunus persica $]$ & $4 \times 10^{-66}$ & \\
\hline PpB18 & DR & 2 & NAC domain protein, IPR003441 [Populus trichocarpa] & $7 \times 10^{-47}$ & 1 \\
\hline PpB19 & $\mathrm{DR} / \mathrm{SZ}$ & 2 & zinc finger protein [Camellia sinensis] & $4 \times 10^{-27}$ & 1 \\
\hline PpB20 & $\mathrm{DR} / \mathrm{SZ}$ & 2 & GRAS family transcription factor [Populus trichocarpa] & $1 \times 10^{-111}$ & \\
\hline PpB21 & DR & 1 & NAC domain protein NAC1 [Gossypium hirsutum $]$ & $3 \times 10^{-35}$ & 1 \\
\hline $\mathrm{PpB} 22$ & DR & 1 & zinc finger protein, putative [Ricinus communis] & $9 \times 10^{-59}$ & \\
\hline PpB23 & DR & 1 & Mitogen-activated protein kinase kinase kinase, $[$ Ricinus communis $]$ & $7 \times 10^{-60}$ & 1 \\
\hline $\mathrm{PpB} 24$ & DR & 1 & transcription factor AP2-EREBP [Lotus japonicus] & $2 \times 10^{-29}$ & \\
\hline PpB25 & $\mathrm{DR} / \mathrm{SZ}$ & 1 & sensory transduction histidine kinase, putative [Ricinus communis] & $2 \times 10^{-68}$ & \\
\hline PpB26 & $\mathrm{DR} / \mathrm{SZ}$ & 1 & dam4 [Prunus persica] & $6 \times 10^{-41}$ & 1 \\
\hline PpB27 & $\mathrm{DR} / \mathrm{SZ}$ & 1 & GRAS family transcription factor [Populus trichocarpa] & $5 \times 10^{-78}$ & \\
\hline \multicolumn{6}{|c|}{ (1) } \\
\hline $\mathrm{PpB} 28$ & $\mathrm{DR} / \mathrm{SZ}$ & 8 & plasma membrane intrinsic protein 2-2 [Pyrus communis] & $2 \times 10^{-82}$ & \\
\hline PpB29 & $\mathrm{DR} / \mathrm{SZ}$ & 2 & forisome [Canavalia gladiata] & $1 \times 10^{-18}$ & \\
\hline РpB30 & $\mathrm{DR} / \mathrm{SZ}$ & 1 & sorbitol transporter [Prunus cerasus] & $1 \times 10^{-64}$ & 1 \\
\hline PpB31 & $\mathrm{DR} / \mathrm{SZ}$ & 1 & Mitochondrial carnitine/acylcarnitine carrier protein, $[$ Ricinus communis $]$ & $3 \times 10^{-26}$ & \\
\hline PpB32 & $\mathrm{DR} / \mathrm{SZ}$ & 1 & sieve element-occluding protein 3 [Medicago truncatula] & $2 \times 10^{-33}$ & \\
\hline \multicolumn{6}{|c|}{ 然 } \\
\hline PpB33 & $\mathrm{DR} / \mathrm{ZS}$ & 3 & pollen coat-like protein $[$ Arabidopsis thaliana $]$ & $3 \times 10^{-16}$ & 1,2 \\
\hline PpB34 & DR & 1 & peripheral-type benzodiazepine receptor, putative [Ricinus communis] & $3 \times 10^{-45}$ & \\
\hline PpB35 & DR & 1 & predicted protein [Populus trichocarpa $]$ & $4 \times 10^{-14}$ & \\
\hline РpB36 & DR & 1 & indole-3-glycerol phosphate lyase IGL1 [Lamium galeobdolon] & $9 \times 10^{-55}$ & \\
\hline PpB37 & DR & 1 & poly(A)-binding protein C-terminal interacting protein 6 [Cucumis sativus] & $2 \times 10^{-23}$ & 1 \\
\hline PpB38 & DR & 1 & putative ripening-related protein [Vitis vinifera] & $4 \times 10^{-31}$ & \\
\hline PpB39 & $\mathrm{DR} / \mathrm{SZ}$ & 1 & Anthranilate N-benzoyltransferase protein, putative [Ricinus communis] & $4 \times 10^{-60}$ & \\
\hline PpB40 & $\mathrm{DR} / \mathrm{SZ}$ & 1 & 3'-N-debenzoyl-2'-deoxytaxol N-benzoyltransferase, [Ricinus communis] & $6 \times 10^{-26}$ & \\
\hline PpB41 & $\mathrm{DR} / \mathrm{ZS}$ & 1 & conserved hypothetical protein [Ricinus communis] & $1 \times 10^{-75}$ & \\
\hline PpB42 & $\mathrm{DR} / \mathrm{ZS}$ & 1 & light harvesting chlorophyll a /b binding protein [Hedera helix] & $2 \times 10^{-38}$ & \\
\hline PpB43 & $\mathrm{DR} / \mathrm{SZ}$ & 6 & & & 1 \\
\hline PpB44 & $\mathrm{DR} / \mathrm{SZ}$ & 4 & & & 1,2 \\
\hline PpB45 & $\mathrm{DR} / \mathrm{ZS}$ & 1 & & & 1,2 \\
\hline PpB46 & $\mathrm{DR} / \mathrm{ZS}$ & 1 & & & \\
\hline
\end{tabular}

The number of ESTs corresponding to each unigene and the Blastx best hit found in the non-redundant protein database from the National Center for Biotechnology Information (NCBI) are shown. ESTs described in previous works are labelled with 1 (Ogundiwin et al., 2008) or 2 (Bassett et al., 2006). 
Table 2.4 List of unigenes exclusively enriched in the 'Zincal 5' (ZS) or 'Springlady' (SZ) samples.

\begin{tabular}{lcclcc}
\hline Unigenes & $\begin{array}{c}\text { Expression } \\
\text { group }\end{array}$ & EST & \multicolumn{1}{c}{ Blastx hit } & $\begin{array}{c}\text { Blastx } \\
\text { E-value }\end{array}$ & $\begin{array}{c}\text { Previous } \\
\text { works }\end{array}$ \\
\hline PpB94 & SZ & 22 & & & \\
PpB95 & SZ & 9 & UVI4 (UV-B-INSENSITIVE 4) [Arabidopsis thaliana] & $1 \times 10^{-16}$ & \\
PpB96 & SZ & 2 & putative RNA binding protein [Nicotiana tabacum] & $1 \times 10^{-130}$ & 2 \\
PpB97 & SZ & 1 & sorbitol-6-phosphate dehydrogenase [Prunus persica] & $4 \times 10^{-50}$ & $5 \times 10^{-25}$ \\
PpB98 & SZ & 1 & small basic intrinsic protein 1 [Vitis vinifera] & $5 \times 10^{-13}$ & 1 \\
PpB99 & SZ & 1 & hypothetical protein [Vitis vinifera] & $1 \times 10^{-14}$ & 1 \\
PpB100 & ZS & 2 & hypothetical protein [Vitis vinifera] & & 2 \\
PpB101 & ZS & 2 & & \\
\hline
\end{tabular}

The number of ESTs corresponding to each unigene and the Blastx best hit found in the non-redundant protein database from the National Center for Biotechnology Information (NCBI) are shown. ESTs described in previous works are labelled with 1 (Ogundiwin et al., 2008) or 2 (Bassett et al., 2006).

Such simple functional classification gave rise to interesting observations when relating to SSH groups: The RD unigenes were abundant in metabolism and oxidation-reduction categories, whereas DR group contained numerous unigenes related to stress and defence. On the other hand, the signalling and transport categories were rich in DR and SZ unigenes (Table 2.5).

Table 2.5. Functional classification of unigenes.

\begin{tabular}{ccccc}
\hline Functional classification & DR & RD & ZS & SZ \\
\hline Metabolism & 5 & 16 & 7 & 4 \\
Oxidation-reduction & 2 & 6 & 2 & 2 \\
Stress and defence & 8 & 2 & 4 & 1 \\
Signalling and transcription & 12 & 3 & 2 & 7 \\
Transport & 5 & 2 & 2 & 6 \\
Other & 14 & 18 & 21 & 11 \\
\hline
\end{tabular}

\section{Real time RT-PCR analysis of selected unigenes}

In order to confirm the developmental and genotype-dependent regulation of genes obtained in this study, we selected nine unigenes for quantitative expression analysis on RNA collected from flower buds of 'Springlady' and 'Zincal 5' cultivars at different times during dormancy progression and release. An Actin gene was used as reference and $D A M 1$ as a control gene showing down-regulated expression during the time interval of the experiment (Figure 2.3). As formerly described by Li et al. (2009), DAM1 expression level was higher in October sample and dropped to undetectable levels in the February and January samples of 'Springlady' and 'Zincal 5' respectively. In agreement with the hypothesized role of $D A M$ genes in maintenance of the dormant state, DAMI expression was very similar in both cultivars in dormant samples but drastically decreased in December in 'Zincal 
5', roughly coinciding with dormancy release. Coherently, 'Springlady' maintained high levels of DAM1 transcript until January, when buds break dormancy. Another MADS box transcription factor gene from the same family (DAM6), which was obtained in our SSH experiment under the name PpB17, followed an expression pattern different to DAM1 but also correlated with the distinct chilling requirements of the studied cultivars. DAM6 cDNA accumulated in November sample and abruptly fell in December in 'Zincal 5', whereas 'Springlady' levels decreased in January.

Other regulatory unigenes coding for a Zn-finger transcription factor (PpB19) and a putative GRAS-like (GIBBERELLIN ACID INSENSITIVE, REPRESSOR of GA1 and SCARECROW) regulator (PpB20) were selected for real time PCR validation. PpB19 expression showed a gradual decrease in 'Zincal 5' genotype from October to January, reaching a final amount of transcript about five times lower than in the first collected sample. However 'Springlady' maintained similar PpB19 values during the same period to finally drop in February. On the other hand, GRAS-like PpB20 led to a particular profile with punctual variations in expression. Unigene PpB29, coding for a forisome-like protein, was also down-regulated during progression and release of bud dormancy, with consistently lower cDNA levels in 'Zincal 5' than in 'Springlady' from November to January. PpB43 unigene, having no relevant similarities to any known gene in databases, maintained a low and constant expression level in 'Zincal 5' from October to January, whereas expression in 'Springlady' was higher and more variable during this period.

On the other hand, unigenes $\mathrm{PpB} 62$, $\mathrm{PpB} 71, \mathrm{PpB} 87$ and $\mathrm{PpB} 88$, respectively coding for a putative flavonoid 3-hydroxylase, a putative DNA-binding protein and two polypeptides with no homology in databases, showed a similar pattern of mRNA accumulation in January and February, just after budbreak, and much more intense signals in 'Zincal 5' than in the 'Springlady' background. In order to highlight the late increase in expression of these four genes in both genotypes, different graph scales have been employed for 'Zincal 5' and 'Springlady' data in Figure 2.3.

\section{Discussion}

Some details on the physiological behaviour of flower buds from 'Zincal 5' and 'Springlady' are shown. The difference in chilling requirement between both cultivars was estimated to be about 100 $\mathrm{CH}$, which is relatively low when considering that certain peach genotypes have requirements higher than $1000 \mathrm{CH}$. However under the mild climate conditions where this experiment has been performed high chilling genotypes cannot be properly cultivated. Despite this limitation, the selected genotypes clearly showed different dormancy-related behaviour during several years, and 
more relevantly, 'Zincal 5' but not 'Springlady' was able to budbreak to some extent before the fulfillment of its chilling requirement.

The SSH procedure was designed to achieve a list of genes related to dormancy maintenance and release. The DR and RD SSH samples were expected to yield transcripts respectively repressed and induced during the $\mathrm{CH}$ accumulation and dormancy release in the 'Springlady' background. On the other hand, the ZS and SZ samples were obtained to identify genotype-dependent differences in expression following dormancy release, which could account for some qualitative genetic differences between 'Zincal 5' and 'Springlady' cultivars related to dormancy release.

A low percentage of the 2496 clones contained in the four SSH libraries could be validated by microarray hybridization of SSH final products. By considering 2 fold differences as a threshold for the signal ratio between forward and reverse probes $(\mathrm{M}=1)$, the interval of validated clones ranged from $15 \%$ to $48 \%$, similar to the $29 \%$ of differentially expressed clones found in a recent SSH work on bud dormancy in apricot (Yamane et al., 2008). These results suggest that simple selection and sequencing of SSH obtained clones could not be a completely reliable procedure to identify differentially expressed genes. Alternatively, such low SSH efficiency may be due to the transcriptional similarity between compared samples, showing a low number of differential transcripts. Under this consideration the comparatively better efficiency of RD library could be due to the existence of a relevant number of up-regulated genes along flower bud development and dormancy release.

Overlapping of unigene groups shows a bias towards the coincidence of RD and ZS enriched unigenes on the one hand and DR and SZ on the other, which in fact confers a high degree of interest to those genes. Whereas unigenes contained exclusively into RD or DR groups could be regulated by flower development processes or by different environmental stresses, and ZS or SZ enriched unigenes could simply correspond to genotype specific genes; RD/ZS and DR/SZ overlapping unigenes are more likely related to bud dormancy due to their double, developmental and genotype dependent regulation.

A rough functional classification of unigenes highly similar to genes described in other species showed evident differences between the four groups. In group RD, sequences related to metabolism and oxidation-reduction were the most abundant, which fits well with the idea that some basic metabolic activation is required to restart growth and cell division following dormancy and with 

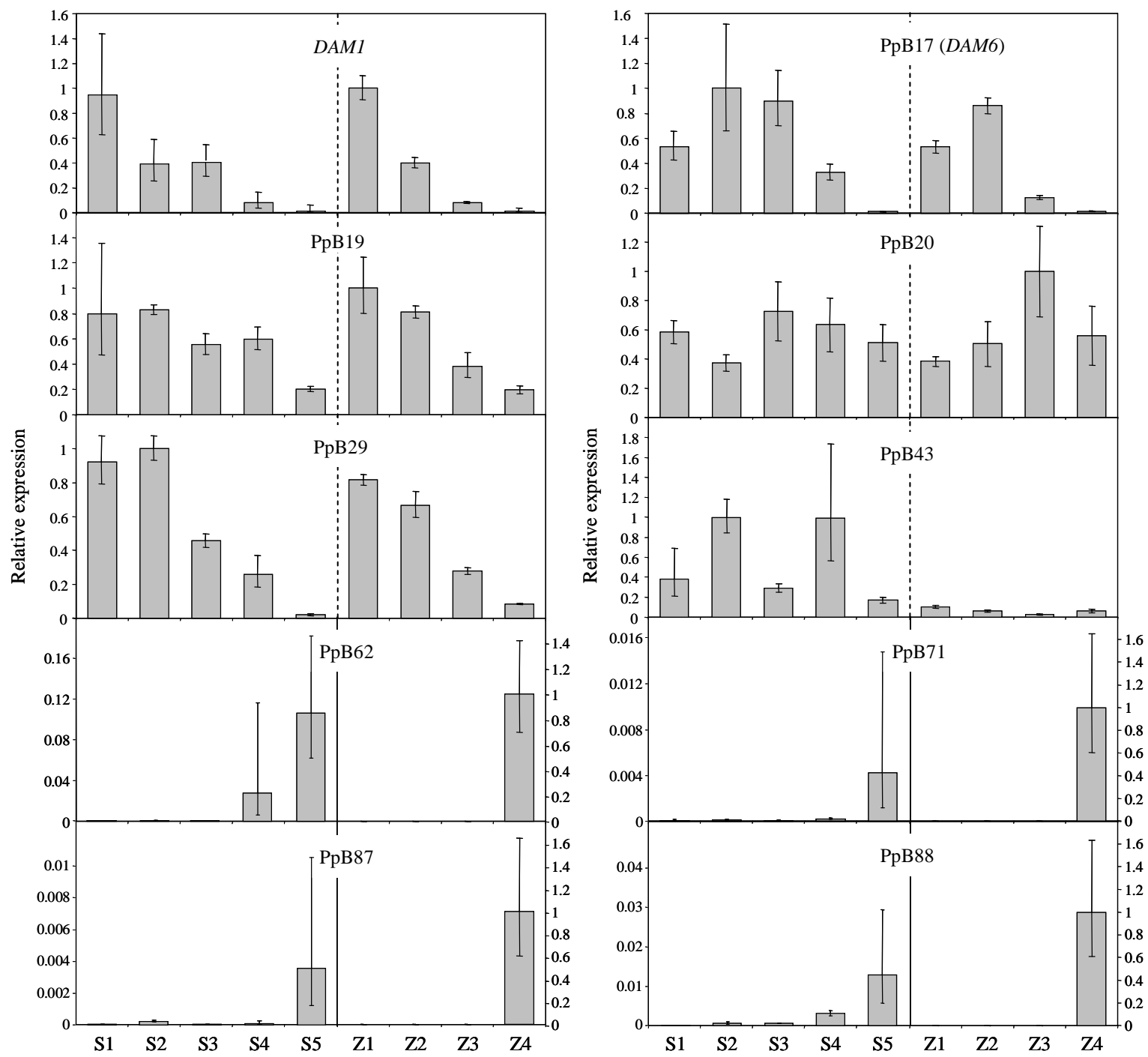

Figure 2.3. Real time RT-PCR analysis of selected unigenes. RNA samples were obtained from 'Springlady' and 'Zincal 5' flower buds harvested during the first days of October (S1 and Z1), November (S2 and Z2), December (S3 and Z3), January (S4 and Z4) and February (S5). Expression levels are relative to actin. An expression value of one is assigned to the sample with a higher accumulation of transcript. Different graph scales have been employed for 'Springlady' and 'Zincal 5' data in unigenes PpB62, PpB71, PpB87 and PpB88. Data are means from two biological replicates, with error bars representing standard deviations.

those previous works linking oxidative stress and dormancy release (Nir et al., 1986; Scalabrelli et al., 1991; Or et al., 2002). On the other side, group DR was rich in stress and defence genes, as dormant tissues must be prepared against drought and cold stresses appearing during winter time. Moreover, the high presence in this group of unigenes related to signalling and transcription suggests that certain developmental processes might be tightly regulated at the transcriptional level in the dormant stage. SZ and ZS groups reproduced respectively DR and RD tendencies in most of the categories. 
Some of the genes found in this work were previously identified in a SSH approach to isolate genes regulated by low temperature and photoperiod in peach bark (Bassett et al., 2006), whereas a high percentage of them were isolated from two cDNA libraries enriched in cold treated fruit mesocarp (Ogundiwin et al., 2008). Respectively 9 and 24 unigenes are coincident with these works, coding for a late embryogenesis abundant protein, a dehydrin, two NAC-like transcription factors, a sorbitol transporter and distinct peroxidases among others. Such a high degree of coincidence with works performed on bark and fruit mesocarp suggests that cold and light regulated pathways share common elements between flower buds and these tissues.

The unigenes $\mathrm{PpB} 16, \mathrm{PpB} 17$ and PpB26 are part of six similar genes located in tandem in linkage group 1 (DAM5, DAM6 and DAM4 respectively), which are related to the early flowering genes SHORT VEGETATIVE PHASE (SVP) and AGAMOUS LIKE24 (AGL24) of Arabidopsis thaliana. A deletion affecting these $D A M$ genes has been found linked to the dormancy induction defects observed in the evergrowing (evg) mutant of peach, showing constant growth in terminal meristems and a defect in terminal vegetative bud formation (Bielenberg et al., 2008). Additional evidences suggesting a role of $D A M$-like genes in regulating dormancy transitions have been obtained in transcriptomic studies in raspberry (Mazzitelli et al., 2007), japanese apricot (Yamane et al.,2008) and leafy spurge (Horvath et al., 2008). The real time RT-PCR analysis of DAM1 and DAM6 essentially confirms previously published data by Li et al. (2009) with some relevant genotype dependent particularities. DAMI and DAM6 major down-regulation started about one month earlier in 'Zincal 5' that in 'Springlady', which is approximately coincident with their specific chilling requirements for dormancy release. Transcript accumulation of the DAM6 gene followed that of the DAM1 gene (Bielenberg et al., 2008; Li et al., 2009) suggesting a kind of sequential regulation between them that deserves further study. This work offers additional evidences on the relevant role of $D A M$ genes in delaying dormancy release, but a deeper analysis of $D A M$ genes expression and further biotechnological approaches are required to uncover molecular and physiological details on their function. In addition to DAM-like genes, SSH analysis of bud dormancy transcriptome of the related species Prunus mume (japanese apricot) provided a cytochrome P450 EST (AB437326) similar to PpB7 and two xyloglucan endotransglycosylase ESTs (AB437332, AB437340) related to PpB59 (Yamane et al., 2008). Such low number of coincidencies between species from the common genus Prunus may be due to the few ESTs described in the japanese apricot article (26) and to the nature of the SSH procedure that produces adjacent $R s a I$ fragments proceeding from the same gene but not matching by BLAST analysis. 
Circadian clock and dormancy have been associated by two recent articles in chestnut, showing that CsTOC1 (TIMING OF CAB, CHLOROPHYLL A/B BINDING PROTEIN EXPRESSION 1), CsLHY (LATE ELONGATED HYPOCOTYL), CsPRR5, CsPRR7 and CsPRR9 (PSEUDO-RESPONSE REGULATOR) genes, coding for homologs to components of the Arabidopsis circadian oscillator, lose their circadian daily regulation during winter dormancy and under low temperature incubation (Ramos et al., 2005; Ibáñez et al., 2008). One of the peach unigenes accumulating in dormant buds (PpB25) showed high similarity to CsPRR7, which in addition to the observation by Horvath et al. (2008) that several circadian regulatory genes are up-regulated following the paradormancyendodormancy transition, increases the accumulated evidence that connects circadian clock with dormancy.

In close linkage to circadian mechanisms are the light signal transduction networks triggered by phytochromes. PpB20 and PpB27 unigenes code for putative GRAS transcription factors that could proceed from the same locus and are very similar to the PAT1 (PHYTOCHROME A SIGNAL TRANSDUCTION) gene from Arabidopsis thaliana. A truncated version of PATl strongly reduces far-red light signaling mediated by phytochrome A (Bolle et al., 2000). Despite the fact that PpB20 average expression was slightly higher in December, when photoperiod is shorter, no reliable conclusions about the light regulation of this gene could be reached due to the absence of significant difference. Other transcription factors identified in this work have different structural or functional domains, as NAC (PpB18 and PpB21), Zn-finger (PpB19 and PpB22), AP2 (PpB24), AT-hook (PpB71), bHLH (PpB72) and PHD-finger (PpB73). The Zn-finger PpB19 showed an attenuated $D A M 1$-like decreasing expression profile after quantitative analysis, which confers to this unigene a high interest for studies of transcriptional regulation related to the dormancy process.

The PpB29 and PpB32 unigenes, up-regulated in dormant buds, are very similar to components of the forisome, a protein aggregate of sieve elements of Fabacean plants that occludes them in a reversible and regulated manner (Noll et al., 2007; Pélissier et al., 2008). Real time analysis of PpB29 showed a gradual drop in expression from December to February, with a significant lower transcript accumulation in the 'Zincal 5' genotype. One attractive idea is that forisome-like structures could be mediating the temporary obstruction of vascular elements to reduce solute exchange and water mobility in dormant buds, but the absence of reports about forisome-like complexes in non-Fabacean plants raises obvious objections. Additional efforts to unravel the activity of these forisome-like elements in other species would help to hypothesize a new role for them in bud dormancy. 
Among the unigenes up-regulated in dormancy released buds, abundant peroxidase-like sequences were found (PpB63, PpB64, PpB65 and PpB67). Previously, other peroxidases have been related to the fulfillment of the chilling requirement in Vitis riparia buds (Mathiason et al., 2009) and to dormancy release in buds of leafy spurge (Jia et al., 2006). Earlier studies suggest a role of hydrogen peroxide $\left(\mathrm{H}_{2} \mathrm{O}_{2}\right)$ in budbreak regulation, based on catalase activity inhibition and $\mathrm{H}_{2} \mathrm{O}_{2}$ accumulation occurring during the natural or hydrogen cyanamide induced breaking of bud dormancy in grapevine (Nir et al., 1986; Pérez et al., 2008). This points to a putative detoxifying role of peroxidases by degrading $\mathrm{H}_{2} \mathrm{O}_{2}$ produced during budbreak. Other RD unigenes are most likely involved in flower development pathways, as the ones coding for the anthocyanin biosynthetic enzymes chalcone synthase (PpB51 and PpB57), dihydroflavonol 4-reductase (PpB53, PpB55 and PpB56) and flavonoid 3-hydroxylase (PpB62).

Comparison of microarray data obtained in leafy spurge with previous studies in different species contributed to identify general processes related to bud dormancy, as cold and stress responses, circadian regulation, flowering time, chromatin remodelling and hormone responses (Horvath et al. 2008). Similarity of some of our unigenes to several of those general factors suggests that such interspecific pathways and processes are most likely conserved in peach. For instance ICE1-like transcription factors involved in cold response were identified in at least three dormancy studies in different species and also in this work (PpB72). Similarly, late embryogenesis abundant proteins (PpB9), dehydrins (PpB11), peroxidases (PpB63, PpB64, PpB65 and PpB67), UDP-galactose 4epimerases (PpB1), chalcone synthases (PpB51 and PpB57), xyloglucan endotransglucosylases (PpB59) and flavonoid 3-hydroxylases (PpB62) among others have been recurrently described in previous articles (Schrader et al., 2004; Jia et al., 2006; Mazzitelli et al., 2007; Rohde et al., 2007; Horvath et al., 2008; Xin et al., 2008; Yamane et al., 2008; Mathiason et al., 2009). Such ESTs and other related to plant dormancy for the first time in this work provide insight into the signals and processes regulating bud dormancy in general, and offer a series of gene sequences susceptible to be used for marker-assisted selection in peach breeding.

\section{Funding}

Instituto Nacional de Investigación y Tecnología Agraria y Alimentaria (INIA)-FEDER (RTA200700060-00-00); Instituto Valenciano de Investigaciones Agrarias provided a PhD fellowship to C.L. 


\section{Acknowledgements}

The authors would like to thank Dr. Horvath for the valuable revision of the MS and Drs Antonio Granell and Clara Pons for their experimental advice.

\section{Supplementary data}

Supplementary Table S2.1. Accession number of ESTs.

Supplementary Table S2.2 List of primers used in this work.

This material is contained in the CD annexed to this thesis. 




\section{Histone modifications and expression of DAM6 gene in peach are modulated during bud dormancy release in a cultivar-dependent manner}

Leida C., Conesa A., Llácer G., Badenes M.L. and Ríos G. 2012 Histone modifications and expression of DAM6 gene in peach are modulated during bud dormancy release in a cultivardependent manner. New Phytologist 193: 67-80. 



\section{Abstract}

Bud dormancy release in many woody perennial plants responds to the seasonal accumulation of chilling stimulus. MADS-box transcription factors encoded by DORMANCY ASSOCIATED MADSbox $(D A M)$ genes in peach (Prunus persica) are implicated in this pathway, but other regulatory factors remain to be identified. In addition, the regulation of DAM gene expression is not well known at the molecular level.

A microarray hybridization approach was performed to identify genes whose expression correlates with the bud dormancy-related behaviour in ten different peach cultivars. Histone modifications in DAM6 gene were investigated by chromatin immunoprecipitation in two different cultivars.

The expression of DAM4-6 and several genes related to ABA and drought stress response correlated with the dormancy behaviour of peach cultivars. The trimethylation of histone H3 at K27 in the DAM6 promoter, coding region and the second large intron was preceded by a decrease of acetylated $\mathrm{H} 3$ and trimethylated $\mathrm{H} 3 \mathrm{~K} 4$ in the region of translation start, coinciding with repression of DAM6 during dormancy release.

Analysis of chromatin modifications reinforced the role of epigenetic mechanisms in DAM6 regulation and bud dormancy release, and highlighted common features with the vernalization process in Arabidopsis thaliana and cereals.

\section{Introduction}

In different plant lineages, adaptation of flowering time to seasonal fluctuations in temperature has been achieved through similar mechanisms with lineage-specific features. Brassicaceae and cereals avoid premature flowering in the autumn by vernalization which inhibits the transition from the vegetative to the reproductive phase until exposure to a prolonged cold period. Similarly, during autumn and winter many perennial species keep the reproductive tissue in a dormant stage (endodormancy, abbreviated to dormancy in this work) inside specialized organs named buds, which are then activated by a period of chilling in a genotype-dependent fashion. These processes are regulated by a set of related MADS-box transcription factors (Hemming \& Trevaskis, 2011).

In Arabidopsis thaliana, the MADS-box transcription factor FLOWERING LOCUS C (FLC) prevents the flowering transition by repressing the floral integrator genes FLOWERING LOCUS T and SUPPRESSOR OF OVEREXPRESSION OF CONSTANS 1 (Searle et al., 2006). The FLC transcript decreases quantitatively during cold exposure by an epigenetic mechanism involving the synthesis of non-coding RNAs and the binding of the Polycomb group (PcG) proteins (De Lucía et 
al., 2008; Swiezewski et al., 2009; Heo \& Sung, 2011). PcG complexes ensure stable repression of FLC after subsequent cell divisions by means of chromatin modifications including trimethylation of histone H3 at lysine 27 (H3K27me3) (Doyle \& Amasino, 2009). In cereals, vernalization is controlled by VERNALIZATION1 (VRN1), a FRUITFULL-like MADS-box gene that contrarily to $F L C$ responds to cold by increasing its expression. Up-regulation of $V R N 1$ during vernalization is associated with reduced $\mathrm{H} 3 \mathrm{~K} 27 \mathrm{me} 3$ and increased histone $\mathrm{H} 3$ lysine 4 trimethylation (H3K4me3) levels at VRN1, a typical mark of transcriptionally active chromatin also found in FLC. These histone modifications suggest a participation of PcG-like complexes in repression of VRN1 prior to winter (Oliver et al., 2009; Hemming \& Trevaskis, 2011).

In peach (Prunus persica), a set of six tandemly repeated SHORT VEGETATIVE PHASE-like MADS-box genes, named DORMANCY ASSOCIATED MADS-boxl-6 (DAM1-6), have been found partially deleted in the evergrowing (evg) mutant showing non-dormant behaviour (Bielenberg et al., 2008). The expression of $D A M$ genes is highly dependent on the establishment, maintenance and release of bud dormancy. Photoperiod length and chilling accumulation have been postulated as the major inputs conditioning seasonal fluctuations in the expression of these genes (Li et al., 2009). $D A M 1$ and DAM6 are up-regulated during bud growth cessation, following a change from long to short day photoperiod (Jiménez et al., 2010a), and down-regulated during dormancy release in two different peach cultivars (Leida et al., 2010). In a recent work, the expression of DAM5 and DAM6 have been found associated to the dormancy status of peach plants treated with prolonged low temperature and with the dormancy-breaking reagent cyanamide (Yamane et al., 2011).

Other $D A M$-like genes showing dormancy-dependent expression in buds have been identified in poplar (Ruttink et al., 2007), raspberry (Mazzitelli et al., 2007), Japanese apricot (Yamane et al., 2008), leafy spurge (Horvath et al., 2008) and blackcurrant (Hedley et al., 2010), suggesting a similar control of bud dormancy in perennial plants. Moreover, the DAM1 gene of leafy spurge shows altered levels of $\mathrm{H} 3 \mathrm{~K} 27 \mathrm{me} 3$ and $\mathrm{H} 3 \mathrm{~K} 4 \mathrm{me} 3$ at two different bud dormancy stages (Horvath et al., 2010) resembling the mechanisms of chromatin regulation observed in FLC and VRN1.

We have performed a genome-wide search for peach genes related to bud dormancy by hybridizing a cDNA microarray containing bud-enriched probes (Leida et al., 2010) with RNA samples from cultivars showing diverse dormancy behaviour, followed by an expression correlation analysis. The DAM6 gene identified in this study was subjected to a detailed analysis by localizing histone H3 modifications associated to dormancy release in its promoter and coding region. 


\section{Materials and Methods}

\section{Plant material and growth conditions}

The Prunus persica [L.] Batsch cv 'Red Candem', 'Flor Red', 'May Glo', '86-6', 'Precocinho', 'Sunraycer', 'Carolina', 'Crimson Baby', 'Rose Diamond' and 'Big Top' were grown in an orchard located at the Instituto Valenciano de Investigaciones Agrarias (IVIA), in Moncada (Spain), under standard agricultural practices. The samples required for microarray hybridizations were obtained from flower buds collected on 29 December 2008, after a chilling accumulation of $400 \mathrm{~h}$ below $7{ }^{\circ} \mathrm{C}$ or chilling hours $(\mathrm{CH})$. Buds were routinely pooled from shoots obtained from three different trees. Flower buds for chromatin immunoprecipitation assays were collected on the following dates of autumn-winter in 2009-2010: 3 November (0 CH), 29 December (276 CH), 12 January (385 CH), 16 February $(634 \mathrm{CH})$, and 2 March $(684 \mathrm{CH})$ for 'Big Top', and 3 November $(0 \mathrm{CH}), 1$ December $(50 \mathrm{CH}), 15$ December $(187 \mathrm{CH})$ and 29 December $(276 \mathrm{CH})$ for 'Red Candem'.

Incubation of shoots for the determination of bud break and dormancy parameters was performed in a phytotron set at $25^{\circ} \mathrm{C}$, with a $12 / 12 \mathrm{~h}$ photoperiod and $70 \%$ humidity.

\section{Measurement of flowering time, bud break and chilling requirement}

The flowering time of a certain cultivar in the field corresponded to the date in which at least half of flowers were fully open. This measurement was made relative to the earliest flowering date of 'May Glo', and expressed in days.

For measuring the percentage of bud break, 10 excised shoots with four to six flower buds remaining in their upper half were placed with their basal end in water and incubated in a phytotron. The basal ends of the shoots were cut and water was replaced every 2 to $3 \mathrm{~d}$. Bud break was measured as the percentage of open flower buds, showing at least the green tip of the sepals, after $10 \mathrm{~d}$ incubation. Those cultivars with percentage of bud break $<50 \%$ were considered to remain in dormant stage.

For estimating the chilling requirement, bud break was measured periodically during the cold season. Chilling requirement was the time in hours below $7{ }^{\circ} \mathrm{C}(\mathrm{CH})$ recorded for a given cultivar when its percentage of bud break exceeded $50 \%$. 


\section{Isolation of RNA and mRNA purification}

For microarray hybridization, total RNA was isolated from $1.5 \mathrm{~g}$ of flower buds by a guanidine thiocyanate-based protocol (Salzman et al., 1999). Poly(A)+ RNA was subsequently purified using the Oligotex mRNA Purification System (Qiagen) from 180 to $250 \mu \mathrm{g}$ of total RNA, according to the manufacturer's instructions. The poly(A)+ RNA was concentrated by precipitation with two volumes of ethanol, in the presence of $33 \mathrm{mM} \mathrm{NaCl}$ and GlycoBlue Coprecipitant (Ambion), then washed with ethanol $80 \%(\mathrm{v} / \mathrm{v})$, and dissolved in RNase-free water. The poly(A)+ RNA concentration in the solution was measured with the Quant-iT RiboGreen RNA Assay Kit (Invitrogen).

For quantitative real-time reverse transcription PCR (RT-PCR) experiments, total RNA was isolated from $100 \mathrm{mg}$ of flower buds using the RNeasy Plant Mini Kit (Qiagen), but adding $1 \%$ (w/v) polyvinylpyrrolidone (PVP-40) to the kit extraction buffer before use.

\section{Microarray hybridization}

The poly(A)+ RNA (100 ng) was reverse transcribed, amplified and labelled with the Amino Allyl MessageAmp II aRNA Amplification Kit (Ambion). Cy5 and Cy3 fluorescent dyes were coupled to the amino allyl modified RNA of each sample and a mix of the samples (for reference), respectively. Purified Cy5-labelled sample and Cy3-labelled reference (200 pmol each) were combined, diluted with water to a final volume of $500 \mu \mathrm{l}$, and concentrated until $40 \mu \mathrm{l}$ in a microcon YM-30 filter (Millipore). Half of the mixture $(20 \mu \mathrm{l})$ was vacuum-concentrated until about $4 \mu \mathrm{l}$, then heat-denatured for $2 \mathrm{~min}$ at $80{ }^{\circ} \mathrm{C}$, mixed with $20 \mu \mathrm{l}$ of pre-heated hybridization buffer [5X SSC (75 mM trisodium citrate $\mathrm{pH} 7.0,0.75 \mathrm{M} \mathrm{NaCl}), 50 \%(\mathrm{v} / \mathrm{v})$ formamide, $0.1 \%$ (w/v) SDS, 0.1 $\mathrm{mg} \mathrm{mL}^{-1}$ salmon sperm DNA], and finally applied to the microarray slide, which was previously incubated for at least $1 \mathrm{~h}$ at $42{ }^{\circ} \mathrm{C}$ with prehybridization buffer [5X SSC, $0.1 \%$ (w/v) SDS, $1 \%$ (w/v) bovine serum albumin]. The microarray contained 2496 expressed sequence tags (ESTs) obtained by a subtraction procedure from dormant and non-dormant flower buds of peach, as described by Leida et al. (2010). Hybridization was performed overnight at $42{ }^{\circ} \mathrm{C}$. After hybridization, slides were washed twice at $42{ }^{\circ} \mathrm{C}$ for $5 \mathrm{~min}$ in $2 \mathrm{X}$ SSC- $0.1 \%(\mathrm{w} / \mathrm{v}) \mathrm{SDS}$, followed by two washes at room temperature for $5 \mathrm{~min}$ in $0.1 \mathrm{X} \mathrm{SSC}-0.1 \%(\mathrm{w} / \mathrm{v}) \mathrm{SDS}$, then five washes at room temperature for $3 \mathrm{~min}$ in $0.1 \mathrm{X} \mathrm{SSC}$, and finally rinsed briefly with $0.01 \mathrm{X}$ SSC before drying by centrifugation at $300 \mathrm{rpm}$ for $5 \mathrm{~min}$. 


\section{Microarray data analysis}

Arrays were scanned at 5- $\mu \mathrm{m}$ resolution. $\mathrm{Cy} 3$ and $\mathrm{Cy} 5$ fluorescence intensity was recorded by using a ScanArray Gx scanner (Perkin Elmer). The resulting images were overlaid and spots identified by the ScanArray Express program (Perkin Elmer). Spot quality was confirmed by visual test. Microarray and experiment data have been placed in ArrayExpress database (http://www.ebi.ac.uk/arrayexpress/), with accession number E-MEXP-3201.

For statistical analysis of microarray data, the Gene Expression Profile Analysis Suite (GEPAS) package was employed (Montaner et al., 2006; http://www.gepas.org/). Normalizations within and between arrays were Loess and Scale, respectively. Signal intensities proceeding from duplicated spots were averaged. Identification of ESTs correlating with the different dormancy variables was performed by Pearson's test. The P-value to control the false discovery rate was adjusted with the Benjamini and Hochberg method. ESTs showing a P-value lower than 0.05 were selected for DNA sequencing with primers NP1 or NP2R (Table S3.3) and expression analysis. From 160 ESTs correlating with the chilling requirement variable, 46 showed a higher signal in dormant buds (positive correlation) and 114 in dormancy released buds (negative correlation). With respect to the percentage of bud break, 201 ESTs were found, of which 30 were more abundant in dormant buds and 171 in dormancy released buds. Similarly, from 154 ESTs correlating with the flowering time variable, 58 had a higher expression in dormant buds and 96 in dormancy released buds. After removing the clones producing a bad sequence and the ones having an internal RsaI site, which was indicative of a chimeric rearrangement during the subtraction procedure, 242 ESTs were identified. The accession numbers of these ESTs are listed in Table S3.2. To identify the genes or transcript models containing the positive ESTs, a BLASTN analysis (Altschul et al., 1990) was performed on peach genome sequence database released by the International Peach Genome Initiative (IPGI). A BLASTP analysis of the deduced protein of the different genes or ESTs was made on the nonredundant protein sequence database, to find the closest annotated hits.

To identify the varieties with similar gene expression fingerprints we applied principal component analysis to the initial matrix of 2525 available data considering the 10 varieties as individuals and the genes as variables. The analysis was performed using Statgraphics 5.1 package for windows (Statistical Graphics). 


\section{Real-time RT-PCR}

One microgram of total RNA was reverse transcribed with SuperScript III First-Strand Synthesis System for RT-PCR (Invitrogen) in a total volume of $20 \mu \mathrm{l}$. Two microliter of a 40X diluted firststrand cDNA was used for each amplification reaction in a final volume of $20 \mu l$. Quantitative realtime PCR was performed on a StepOnePlus Real-Time PCR System using the Power SYBR Green PCR Master Mix (Applied Biosystems) and primers shown in Table S3.3. Cycling protocol consisted of $10 \mathrm{~min}$ at $95{ }^{\circ} \mathrm{C}$, followed by 40 cycles of $15 \mathrm{~s}$ at $95{ }^{\circ} \mathrm{C}$ for denaturation, and 1 min at $60{ }^{\circ} \mathrm{C}$ for annealing and extension. Specificity of the PCR reaction was assessed by the presence of a single peak in the dissociation curve after the amplification and through size estimation of the amplified product by agarose electrophoresis. We used as reference a peach actin gene amplified with specific primers (Table S3.3). Relative expression was measured by the relative standard curve procedure. Results were the average of two independent biological replicates repeated twice.

\section{Chromatin immunoprecipitation (ChIP) assays}

Cross-linking of $4 \mathrm{~g}$ of flower buds, and chromatin isolation and sonication were performed according to Saleh et al. (2008), with the following few modifications. For chromatin isolation, we added $5 \mathrm{ml}$ of nuclei isolation buffer to $1 \mathrm{~g}$ of cross-linked frozen material. After homogenization and centrifugation at $11,000 \mathrm{~g}$ for $20 \mathrm{~min}$, we additionally washed the pellet with $5 \mathrm{ml}$ of nuclei isolation buffer. The chromatin was resuspended in $0.5 \mathrm{ml}$ of nuclei lysis buffer and the DNA sheared into fragments of about $500 \mathrm{bp}$ (100 to $1000 \mathrm{bp}$ interval) by sonicating 5 times for $10 \mathrm{~s}$ with $37 \%$ amplitude, on a Vibra-Cell VCX-500 sonicator (Sonics and Materials). Protease inhibitor cocktail (PIC) for plant cell and tissue extracts (Sigma) was added to nuclei isolation buffer and nuclei lysis buffer, to a final concentration of $0.5 \%(\mathrm{v} / \mathrm{v})$ and $1 \%(\mathrm{v} / \mathrm{v})$ respectively. PVP-40 was added to nuclei isolation buffer ( $1 \% \mathrm{w} / \mathrm{v})$ shortly before use.

ChIP was performed according to Sandoval et al. (2004) and Ferres-Maso et al. (2009). The sonicated chromatin was centrifuged at 13,800g for $10 \mathrm{~min}$, and the supernatant diluted 10-fold with dilution buffer [16.7 mM Tris-HCl pH 8.0, $167 \mathrm{mM} \mathrm{NaCl}, 0.01 \%$ (w/v) SDS, $1.1 \%$ (v/v) Triton X100, $1.2 \mathrm{mM}$ EDTA, $0.5 \%(\mathrm{v} / \mathrm{v})$ PIC]. Aliquots of $600 \mu \mathrm{l}$ of diluted chromatin were incubated overnight at $4{ }^{\circ} \mathrm{C}$ on a rotating platform with Dynabeads-Protein $\mathrm{G}$ (Invitrogen) previously washed with PBS buffer $\left(1.8 \mathrm{mM} \mathrm{KH}_{2} \mathrm{PO}_{4}, 10 \mathrm{mM} \mathrm{Na} 2 \mathrm{HPO}_{4}, 2.7 \mathrm{mM} \mathrm{KCl}, 140 \mathrm{mM} \mathrm{NaCl}, 5 \mathrm{mg} \mathrm{mL} \mathrm{m}^{-1}\right.$ bovine serum albumin) and saturated with $2 \mu \mathrm{g}$ of the different antibodies. The employed antibodies were anti-trimethyl-histone H3 (Lys4) [07-473], anti-trimethyl-histone H3 (Lys27) [07-449], and 
anti-acetyl-histone H3 [06-599] from Millipore, and anti-histone H3 [ab1791] from Abcam. Immunocomplexes were recovered using a DynaMag-2 magnetic particle concentrator (Invitrogen). Samples were washed twice with cold low-salt buffer [50 mM Hepes pH 8.0, $140 \mathrm{mM} \mathrm{NaCl,} \%$ (v/v) Triton X-100, $0.1 \%(\mathrm{w} / \mathrm{v})$ sodium deoxycholate, $1 \mathrm{mM}$ EDTA], twice with cold high-salt buffer [50 mM Hepes pH 8.0, $500 \mathrm{mM} \mathrm{NaCl}, 1 \%$ (v/v) Triton X-100, $0.1 \%$ (w/v) sodium deoxycholate, $1 \mathrm{mM}$ EDTA], twice with cold LiCl buffer [10 mM Tris-HCl pH 8.0, $250 \mathrm{mM} \mathrm{LiCl}$, $0.5 \%$ (v/v) Nonidet P40, $0.5 \%$ (w/v) sodium deoxycholate, $1 \mathrm{mM}$ EDTA], and finally once with TE buffer (10 mM Tris-HCl pH 8.0, $1 \mathrm{mM}$ EDTA). Washings were performed at $4{ }^{\circ} \mathrm{C}$ for $4 \mathrm{~min}$, under rotation. After discarding TE buffer, the immunoprecipitated chromatin was eluted from the Dynabead-protein $\mathrm{G}$ by adding $50 \mu \mathrm{l}$ of elution buffer [98 $\mathrm{mM} \mathrm{NaHCO} 3,1 \%$ (w/v) SDS], vortexing and incubating for $10 \mathrm{~min}$ at $65^{\circ} \mathrm{C}$. A second elution step with additional $50 \mu$ of elution buffer was performed. Formaldehyde cross-linking was reversed by incubating overnight at $65^{\circ} \mathrm{C}$ in the presence of proteinase $\mathrm{K}\left(0.4 \mathrm{mg} \mathrm{mL}^{-1}\right)$. DNA was purified with High Pure PCR Product Purification Kit (Roche) and resuspended in $100 \mu \mathrm{l}$ of $10 \mathrm{mM}$ Tris- $\mathrm{HCl} \mathrm{pH}$ 8.0. Chromatin crosslinking and ChIP was made on two independent samples per condition.

Two microliter of DNA was used for each amplification reaction in a final volume of $20 \mu \mathrm{l}$. Quantitative real-time PCR was performed on a StepOnePlus Real-Time PCR System using PerfeCTa SYBR Green SuperMix ROX (Quanta Biosciences) and primers shown in Table S3.3. Cycling protocol consisted of $10 \mathrm{~min}$ at $95{ }^{\circ} \mathrm{C}$, followed by 45 cycles of $15 \mathrm{~s}$ at $95{ }^{\circ} \mathrm{C}$, and 1 min at $60{ }^{\circ} \mathrm{C}$. Specificity of the PCR reaction was assessed as above. The relative standard curve procedure was utilized for quantification. Results were made relative to the anti-histone $\mathrm{H} 3$ reaction. Results were the average of three PCR reactions for each sample.

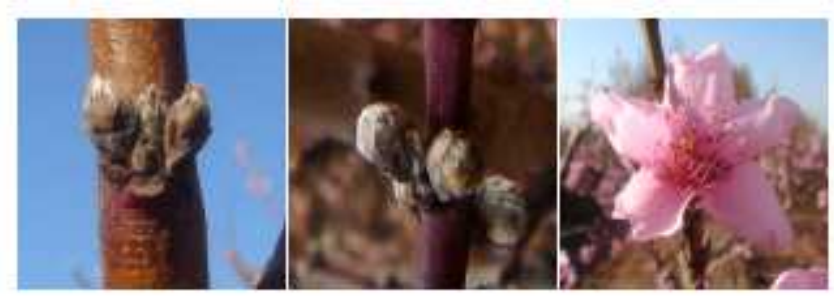

Figure 3.1. Flower developmental changes during dormancy progression and bud break in peach. Two dormant flower buds flanking a vegetative bud are shown on the left panel. In the middle, several swollen flower buds are opening and starting to show the green sepals on their tips. A fully open flower is shown on the right. 


\section{Results}

\section{Dormancy-related behaviour of ten different peach cultivars}

The particular response to climatic and environmental factors affecting bud dormancy in ten peach cultivars was studied by three related methods. The flowering time method integrated complex intrinsic and extrinsic inputs, such as cultivar specific chilling and heat requirements for endodormancy and ecodormancy releases, and the influence of light and meteorological conditions. On the other hand, the measurement of chilling requirement did not account in principle the ecodormancy-related factors and was thus expected to better respond to particular mechanisms overcoming winter. Finally, the percentage of bud break method, measured in samples exposed to $400 \mathrm{CH}$, allowed an additional estimation of cultivar-specific depth of dormancy in a fixed time condition. The peach phenological stages more relevant to this study are shown in Figure 3.1, depicting dormant buds, opening buds showing the green sepals utilized for chilling requirement and bud break estimation, and fully open flowers employed for flowering time determination.

\begin{tabular}{lccc}
\multicolumn{3}{c}{ Table 3.1. Dormancy variables measured for peach cultivars. } \\
\hline Cultivar & $\begin{array}{c}\text { Chilling } \\
\text { requirement } \\
(\mathrm{CH})\end{array}$ & $\begin{array}{c}\text { Bud break } \\
(\%)^{\mathrm{a}}\end{array}$ & $\begin{array}{c}\text { Flowering } \\
\text { time }(\mathrm{d})^{\mathrm{b}}\end{array}$ \\
\hline 'Red Candem' & $<278$ & 76.0 & 4 \\
'Flor Red' & $<278$ & 82.1 & 11 \\
'May Glo' & $278-385$ & 86.1 & 0 \\
'86-6' & $278-385$ & 54.2 & 9 \\
'Precocinho' & $385-412$ & 68.3 & 7 \\
'Sunraycer' & $385-412$ & 66.7 & 9 \\
'Carolina' & $412-511$ & 21.1 & 11 \\
'Crimson Baby' & $412-511$ & 35.6 & 14 \\
'Rose Diamond' & $631-639$ & 0.0 & 28 \\
'Big Top' & $674-712$ & 0.0 & 39 \\
\hline 'Measured after 10 d incubation of 400 CH shoots. 'Days after \\
'May Glo'.
\end{tabular}

The three methods gave essentially different measurements, generating three distinct grading of cultivars according to their dormancy behaviour (Table 3.1). However, comparative analysis of flowering time, chilling requirement and percentage of bud break variables supported an overall classification of cultivars into three major groups. The earliest cultivars 'Red Candem', 'Flor Red', 
'May Glo', '86-6', 'Precocinho' and 'Sunraycer' were not consistently separated by the three methods and showed similar responses to dormancy releasing factors. The varieties 'Rose Diamond' and 'Big Top' were clearly later than the rest of cultivars. Finally, a third group containing 'Carolina' and 'Crimson Baby' had an intermediate behaviour between the early and late groups. This broad classification was useful for a general overview of the plant material studied, however the different nature of the three methods precluded their fusion in a unique joint source of data. Instead of that, the three sets of measurements were utilized independently.

\section{Identification of genes whose expression correlates with cultivar-dependent differences in dormancy}

To search for genes responding to bud dormancy stage in peach, we compared gene expression in flower buds excised from the different cultivars at a fixed date, using a custom microarray. Buds were collected after $400 \mathrm{CH}$, which was supposed to be an intermediate value among the chilling requirements of the studied cultivars. The corresponding percentage of bud break after $10 \mathrm{~d}$ ranged from $0 \%$ ('Rose Diamond' and 'Big Top') to $86.1 \%$ ('May Glo'), a nearly uniform distribution that ensured the utilization of flower buds with diverse degrees of dormancy (Table 3.1). RNA obtained from these buds was labelled and hybridized to a microarray slide containing a set of dormancy-related cDNAs obtained by suppression subtractive hybridization (SSH) in Leida et al. (2010).

In order to determine whether the overall gene expression was conditioned by cultivar-specific factors, a principal component analysis was performed, showing that more than $60 \%$ of the variability in the original data was explained by two principal components. Component two divided the varieties according to their dormancy stage, conferring positive values to the group of six early cultivars and negative values to the others (Figure 3.2). In addition, the intermediate 'Carolina' and 'Crimson Baby', and the relatively late 'Rose Diamond' and 'Big Top' varieties were placed closely, reproducing properly the three-groups classification described above. This result suggested that the dormancy stage of collected buds had a wide influence on gene expression, which in fact validates the use of this transcriptomic approach for identification of dormancy related genes.

A correlation analysis of hybridization signals and the three dormancy variables shown in Table 3.1 was performed using a false discovery rate of 0.05 (Table S3.1). Both positive and negative correlations were obtained for ESTs, which were either more or less abundant in dormant tissues. 
Following the guidelines outlined in Materials and Methods, 242 ESTs were finally identified (Table S3.2).

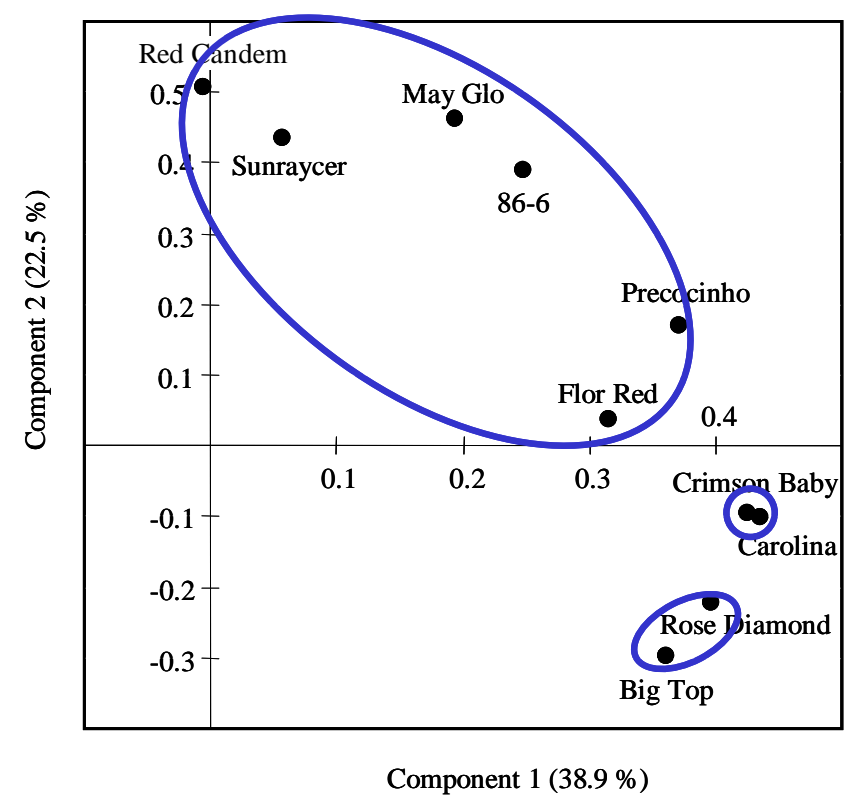

Figure 3.2. Principal component analysis of ESTs signal ratio for the different cultivars assayed. The percentage of the explained variance is shown in parentheses.

A Venn diagram representing the number of ESTs whose expression level correlated with each of the three dormancy-related variables is shown in Figure 3.3(a). Both positive and negative correlations were accounted. The results showed the high degree of overlap between them, with 59 ESTs (from a total of 242) common to chilling requirement, percentage of bud break and flowering time variables, and 39 coincident ESTs in chilling requirement and percentage of bud break analyses. In conclusion, the three variables offered similar results with certain particularities that should be taken into consideration. The hybridization signals of ten ESTs showing better positive and negative correlation with the chilling requirement were respectively plotted in Figure 3.3(b,c) to illustrate their overall cultivar dependence.

Six of these 242 ESTs did not match any of predicted gene models in the peach genome database released by the International Peach Genome Initiative (http://www.rosaceae.org/node/365). Also, two sequences corresponding to the same cDNA were not present in the peach v1.0 genome assembly. The rest of the ESTs matched to 68 transcript models; 45 of them were associated with a higher expression level in dormant buds, and the remaining 23 with higher expression in dormancy released buds. 
(a)

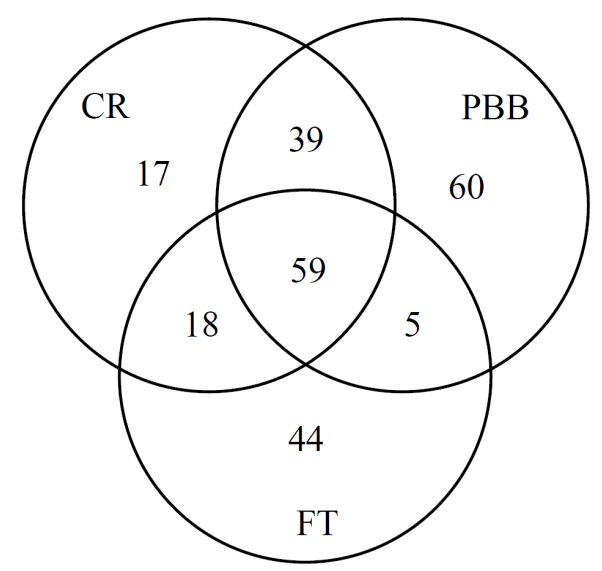

(b)

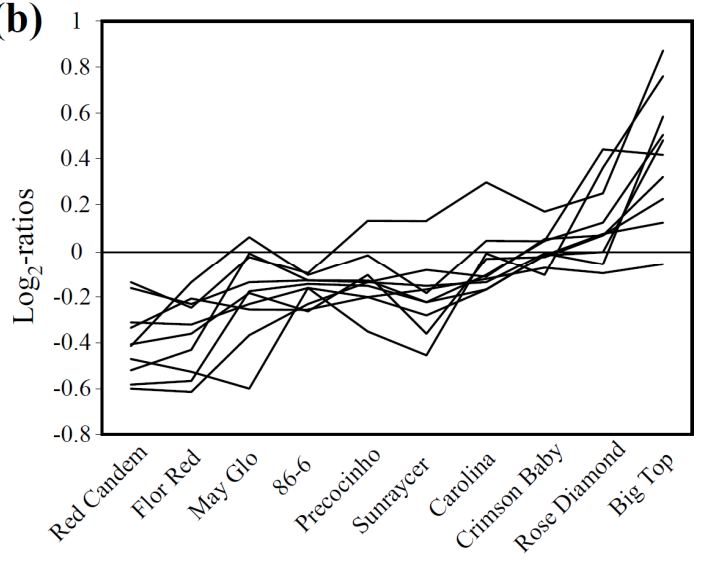

(c)

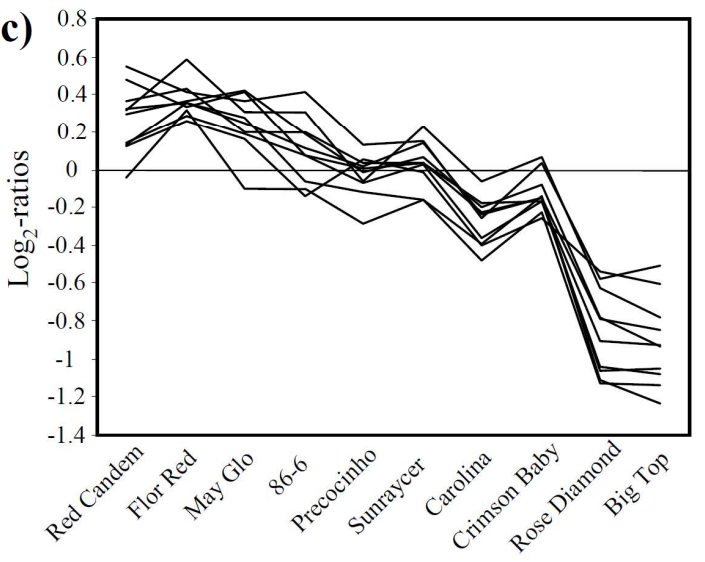

Figure 3.3. Analysis of ESTs correlating with bud dormancy variables. A Venn diagram showing the number of ESTs found under a false discovery rate of 0.05 for chilling requirement (CR), percentage of bud break (PBB) and time to flowering (FT) parameters (a). The normalized $\log 2$ signal ratios of the ten ESTs having better positive (b) and negative (c) correlation values for chilling requirement are plotted. 
Table 3.2. Genes showing higher expression in dormant buds

\begin{tabular}{|c|c|c|c|c|c|c|}
\hline $\begin{array}{l}\text { Transcript } \\
\text { name }\end{array}$ & $\begin{array}{l}\text { Representative } \\
\text { EST }\end{array}$ & $\begin{array}{l}\text { No. of } \\
\text { ESTs }\end{array}$ & BLASTP hit & BLASTP hit annotation & $E$ value & Variable $^{\mathrm{a}}$ \\
\hline ppa008651m & GR410432 & 4 & 1601521B & LEA D-29 gene & $6 \times 10^{-36}$ & FT \\
\hline ppa010714m & JK006283 & 4 & ABJ96360 & DAM6 $[P$. persica $]$ & $2 \times 10^{-132}$ & FT \\
\hline ppa014312m & JK006309 & 4 & ACG24938 & Hypothetical protein [Zea mays] & $9 \times 10^{-25}$ & $\mathrm{CR}, \mathrm{FT}$ \\
\hline ppa010822m & GR410442 & 3 & ABJ96359 & DAM5 $[P$. persica $]$ & $2 \times 10^{-128}$ & $\mathrm{CR}, \mathrm{PBB}, \mathrm{FT}$ \\
\hline Not found & GR410720 & 2 & & & & $\mathrm{PBB}, \mathrm{FT}$ \\
\hline ppa005514m & JK006287 & 2 & AAC49658 & Dehydrin $[P$. persica $]$ & $3 \times 10^{-169}$ & $\mathrm{CR}, \mathrm{FT}$ \\
\hline ppa009007m & GR410685 & 2 & ABQ45405 & Sorbitol-6-phosphate dehydrogenase $[P$. persica $]$ & 0 & FT \\
\hline ppa010086m & JK006300 & 2 & EEF35690 & Ferritin, putative [Ricinus communis] & $2 \times 10^{-95}$ & $\mathrm{CR}$ \\
\hline ppa011123m & GR410688 & 2 & ABJ96358 & DAM4 $[P$. persica $]$ & $2 \times 10^{-122}$ & $\mathrm{CR}, \mathrm{PBB}$ \\
\hline ppa011831m & JK006295 & 2 & CAB85625 & Putative ripening-related protein [Vitis vinifera] & $8 \times 10^{-67}$ & $\mathrm{CR}$ \\
\hline ppa012373m & GR410435 & 2 & ABI31653 & Zinc finger protein [Camellia sinensis] & $2 \times 10^{-62}$ & $\mathrm{CR}, \mathrm{FT}$ \\
\hline ppa001989m & JK006292 & 1 & AAL91171 & Low-temperature-induced $65 \mathrm{kD}$ protein $[$ A. thaliana $]$ & $2 \times 10^{-28}$ & $\mathrm{PBB}, \mathrm{FT}$ \\
\hline ppa002102m & JK006378 & 1 & AAQ23899 & RSH2 [Nicotiana tabacum $]$ & 0 & PBB, FT \\
\hline ppa003017m & JK006373 & 1 & NP_179869 & AtGRF1 (GROWTH-REGULATING FACTOR 1) [A. thaliana] & $2 \times 10^{-97}$ & $\mathrm{PBB}$ \\
\hline ppa003327m & JK006380 & 1 & CAA48630 & 4-alpha-glucanotransferase precursor [Solanum tuberosum] & 0 & PBB \\
\hline ppa005713m & JK006285 & 1 & AAK96816 & Putative B-box zinc finger protein $[$ A. thaliana $]$ & $7 \times 10^{-75}$ & FT \\
\hline ppa005802m & JK006375 & 1 & NP_194274 & ZFWD1 (zinc finger WD40 repeat protein 1) [A. thaliana] & $7 \times 10^{-124}$ & $\mathrm{CR}$ \\
\hline ppa006008m & JK006366 & 1 & NP_564673 & $\begin{array}{l}\text { Peptidoglycan-binding LysM domain-containing protein }[A . \\
\text { thaliana }]\end{array}$ & $8 \times 10^{-13}$ & $\mathrm{CR}, \mathrm{PBB}$ \\
\hline ppa006974m & JK006374 & 1 & NP_564956 & AFP (ABI FIVE BINDING PROTEIN) [A. thaliana] & $2 \times 10^{-62}$ & $\mathrm{CR}, \mathrm{PBB}$ \\
\hline ppa007137m & JK006313 & 1 & AAG01381 & Alcohol dehydrogenase 1 [Vitis vinifera $]$ & 0 & CR, PBB, FT \\
\hline ppa007415m & JK006372 & 1 & XP_002266388 & Similar to $\mathrm{B} 2$ protein [Vitis vinifera] & $6 \times 10^{-118}$ & PBB \\
\hline ppa007606m & JK006297 & 1 & ADE41131 & AP2 domain class transcription factor [Malus $x$ domestica $]$ & $2 \times 10^{-103}$ & $\mathrm{CR}, \mathrm{FT}$ \\
\hline ppa007666m & JK006369 & 1 & EEF30918 & $\begin{array}{l}\text { Palmitoyl-protein thioesterase } 1 \text { precursor, putative [Ricinus } \\
\text { communis] }\end{array}$ & $7 \times 10^{-124}$ & $\mathrm{CR}, \mathrm{PBB}$ \\
\hline ppa008311m & JK006299 & 1 & ABI34650 & bZIP transcription factor bZIP68 [Glycine max] & $4 \times 10^{-44}$ & CR \\
\hline ppa008849m & JK006284 & 1 & ACF06448 & Annexin [Elaeis guineensis] & $1 \times 10^{-129}$ & FT \\
\hline ppa008859m & JK006379 & 1 & ACM45713 & Class I chitinase [Pyrus pyrifolia] & $2 \times 10^{-148}$ & FT \\
\hline ppa008979m & JK006331 & 1 & EEF52342 & R2R3-MYB transcription factor, putative [Ricinus communis] & $8 \times 10^{-92}$ & FT \\
\hline ppa009032m & JK006286 & 1 & EEF52567 & 2-hydroxyacid dehydrogenase, putative [Ricinus communis] & $6 \times 10^{-109}$ & $\mathrm{CR}, \mathrm{FT}$ \\
\hline ppa009498m & JK006370 & 1 & EEF42166 & Homeobox protein, putative [Ricinus communis] & $4 \times 10^{-136}$ & $\mathrm{CR}, \mathrm{PBB}$ \\
\hline ppa010299m & JK006382 & 1 & BAG09366 & $\begin{array}{l}\text { Peroxisomal short-chain dehydrogenase/reductase family protein } \\
\text { [Glycine } \max ]\end{array}$ & $1 \times 10^{-118}$ & CR, PBB, FT \\
\hline ppa010931m & JK006367 & 1 & ABN08437 & Ribosomal protein L10 $[$ Medicago truncatula $]$ & $6 \times 10^{-98}$ & FT \\
\hline ppa011776m & JK006357 & 1 & EEF50502 & Remorin, putative [Ricinus communis] & $2 \times 10^{-60}$ & $\mathrm{CR}$ \\
\hline ppa012188m & JK006293 & 1 & NP_563710 & AWPM-19-like membrane family protein $[$ A. thaliana $]$ & $1 \times 10^{-72}$ & FT \\
\hline ppa012329m & JK006304 & 1 & EEF35031 & $\begin{array}{l}\text { Transcription initiation factor iia (tfiia), gamma chain, putative } \\
\text { [Ricinus communis] }\end{array}$ & $4 \times 10^{-55}$ & FT \\
\hline ppa012578m & JK006359 & 1 & EEF30224 & Conserved hypothetical protein [Ricinus communis] & $3 \times 10^{-46}$ & CR \\
\hline ppa012801m & JK006290 & 1 & NP_195570 & ATFP6 (FARNESYLATED PROTEIN 6) [A. thaliana] & $8 \times 10^{-69}$ & $\mathrm{CR}$ \\
\hline ppa012915m & JK006288 & 1 & CBY94070 & Early responsive to dehydration [Fagus sylvatica] & $5 \times 10^{-41}$ & $\mathrm{CR}, \mathrm{PBB}$ \\
\hline ppa013063m & JK006291 & 1 & NP_197518 & Ribosomal protein $\mathrm{L} 36$ family protein $[$ A. thaliana $]$ & $7 \times 10^{-28}$ & $\mathrm{CR}, \mathrm{PBB}$ \\
\hline ppa013625m & JK006296 & 1 & NP_568818 & Eukaryotic translation initiation factor SUI1, putative [A. thaliana] & $2 \times 10^{-49}$ & $\mathrm{CR}$ \\
\hline ppa013723m & JK006360 & 1 & EEF34837 & $\begin{array}{l}\text { Small nuclear ribonucleoprotein sm d2, putative [Ricinus } \\
\text { communis] }\end{array}$ & $3 \times 10^{-51}$ & CR, PBB, FT \\
\hline ppa014118m & JK006303 & 1 & AAK73280 & Drought-induced protein [Retama raetam $]$ & $1 \times 10^{-3}$ & FT \\
\hline ppa014358m & JK006376 & 1 & EEF30268 & Conserved hypothetical protein [Ricinus communis] & $3 \times 10^{-24}$ & FT \\
\hline ppa015914m & JK006294 & 1 & ABK94181 & Unknown [Populus trichocarpa] & $1 \times 10^{-07}$ & FT \\
\hline ppa017425m & JK006335 & 1 & NP_193292 & MAA3 (MAGATAMA 3) [A. thaliana] & 0 & FT \\
\hline ppa020191m & JK006368 & 1 & BAG80556 & UDP-glucose:glucosyltransferase [Lycium barbarum] & $4 \times 10^{-149}$ & CR, PBB, FT \\
\hline ppa024188m & JK006365 & 1 & NP_564673 & $\begin{array}{l}\text { Peptidoglycan-binding LysM domain-containing protein }[A \text {. } \\
\text { thaliana }]\end{array}$ & $3 \times 10^{-36}$ & CR, PBB \\
\hline Not found & JK006298 & 1 & & & & $\mathrm{CR}, \mathrm{PBB}$ \\
\hline Not found & JK006306 & 1 & & & & $\mathrm{CR}$ \\
\hline
\end{tabular}


Table 3.2 lists transcript models and ESTs with increased expression in dormant buds of the late cultivars. A gene coding for a putative late embryogenesis abundant protein (LEA) was previously reported to depend on the dormancy stage (Leida et al., 2010), and identified also in a transcriptomic approach defining peach mesocarp genes affected by chilling (Ogundiwin et al., 2008). Other genes associated with dormancy in peach are: ppa005514m, coding for a dehydrin from bark tissue that has been described to have a restricted expression pattern in dormancydefective genotypes of peach (Artlip et al., 1997); and DAM4-6 genes, part of a six-member gene family of MADS-box transcription factors that have been postulated to cause dormancy-related alterations in the evg mutant of peach (Bielenberg et al., 2008). The presence of seven additional genes coding for putative transcription factors (ppa003017m, ppa005713m, ppa007606m, ppa008311m, ppa008979m, ppa009498m and ppa012329m) suggests that multiple regulation pathways are involved in dormancy maintenance and bud development processes.

Table 3.3. Genes showing higher expression in non-dormant buds.

\begin{tabular}{|c|c|c|c|c|c|c|}
\hline $\begin{array}{l}\text { Transcript } \\
\text { name }\end{array}$ & $\begin{array}{c}\text { Representative } \\
\text { EST }\end{array}$ & $\begin{array}{l}\text { No. of } \\
\text { ESTs }\end{array}$ & BLASTP hit & BLASTP hit annotation & $E$ value & Variable $^{\mathrm{a}}$ \\
\hline ppa020321m & JK006332 & 69 & EEF52630 & Peroxidase 9 precursor, putative [Ricinus communis] & $3 \times 10^{-146}$ & $\mathrm{CR}, \mathrm{PBB}, \mathrm{FT}$ \\
\hline ppa008309m & GR410503 & 27 & ABW82528 & Class III peroxidase [Gossypium hirsutum] & $9 \times 10^{-119}$ & $\mathrm{CR}, \mathrm{PBB}, \mathrm{FT}$ \\
\hline ppa020886m & GR410508 & 26 & EEF51430 & MEN-8 protein precursor, putative [Ricinus communis] & $5 \times 10^{-21}$ & CR, PBB \\
\hline ppa018509m & GR410669 & 9 & EEF49202 & Lipid binding protein, putative [Ricinus communis] & $3 \times 10^{-32}$ & $\mathrm{CR}, \mathrm{PBB}$ \\
\hline ppa008548m & GR410674 & 5 & EEF38791 & Cinnamoyl-CoA reductase, putative [Ricinus communis] & $4 \times 10^{-153}$ & $\mathrm{PBB}$ \\
\hline ppa017856m & GR410555 & 5 & ACG41003 & Carboxyl-terminal peptidase [Zea mays] & $8 \times 10^{-86}$ & $\mathrm{CR}, \mathrm{PBB}, \mathrm{FT}$ \\
\hline ppa005535m & JK006364 & 4 & AAL26909 & Dehydration-responsive protein RD22 [P. persica $]$ & $1 \times 10^{-81}$ & $\mathrm{CR}, \mathrm{PBB}, \mathrm{FT}$ \\
\hline ppa005767m & JK006334 & 4 & AAL26909 & Dehydration-responsive protein RD22 $[P$. persica $]$ & $6 \times 10^{-82}$ & $\mathrm{CR}, \mathrm{PBB}, \mathrm{FT}$ \\
\hline ppa006739m & GR410750 & 3 & EEF45922 & $\begin{array}{l}\text { Dehydration-responsive protein RD22 precursor, putative [Ricinus } \\
\text { communis] }\end{array}$ & $1 \times 10^{-78}$ & $\mathrm{CR}, \mathrm{PBB}, \mathrm{FT}$ \\
\hline ppa014645m & GR410516 & 3 & ACG41003 & Carboxyl-terminal peptidase [Zea mays] & $1 \times 10^{-84}$ & $\mathrm{CR}, \mathrm{PBB}, \mathrm{FT}$ \\
\hline ppa025857m & GR410576 & 3 & NP_177530 & $\begin{array}{l}\text { Protease inhibitor/seed storage/lipid transfer protein (LTP) family } \\
\text { protein }[\text { A. thaliana }]\end{array}$ & $1 \times 10^{-20}$ & $\mathrm{PBB}, \mathrm{FT}$ \\
\hline Not found & JK006315 & 3 & & & & $\mathrm{CR}, \mathrm{PBB}$ \\
\hline ppa009789m & GR410684 & 2 & NP_196821 & $\begin{array}{l}\text { SAG29 (SENESCENCE-ASSOCIATED PROTEIN 29) [A. } \\
\text { thaliana] }\end{array}$ & $2 \times 10^{-85}$ & PBB \\
\hline ppa021109m & JK006325 & 2 & EEF51426 & $\begin{array}{l}\text { Nonspecific lipid-transfer protein precursor, putative [Ricinus } \\
\text { communis] }\end{array}$ & $9 \times 10^{-32}$ & PBB \\
\hline ppa003039m & JK006342 & 1 & EEF48818 & Proteasome-activating nucleotidase, putative [Ricinus communis] & 0 & CR, PBB \\
\hline ppa003411m & JK006371 & 1 & EEF32187 & L-ascorbate oxidase, putative [Ricinus communis] & 0 & $\mathrm{CR}, \mathrm{PBB}, \mathrm{FT}$ \\
\hline ppa003797m & GR410504 & 1 & EEE82643 & Acyl:coa ligase [Populus trichocarpa] & 0 & FT \\
\hline ppa004872m & JK006302 & 1 & XP_002268893 & Hypothetical protein [Vitis vinifera] & 0 & $\mathrm{CR}, \mathrm{PBB}, \mathrm{FT}$ \\
\hline ppa006506m & GR410648 & 1 & AAO42227 & Putative strictosidine synthase $[$ A. thaliana $]$ & 0 & $\mathrm{CR}$ \\
\hline ppa006852m & JK006362 & 1 & EEE85993 & Chs-like protein [Populus trichocarpa] & 0 & CR \\
\hline ppa010924m & JK006328 & 1 & NP_181525 & $\begin{array}{l}\text { Microsomal signal peptidase } 25 \mathrm{kDa} \text { subunit, putative (SPC25) [A. } \\
\text { thaliana] }\end{array}$ & $1 \times 10^{-71}$ & CR, FT \\
\hline ppa020936m & JK006318 & 1 & AAL26909 & Dehydration-responsive protein RD22 $[P$. persica $]$ & $5 \times 10^{-94}$ & FT \\
\hline ppa025137m & JK006336 & 1 & XP_002277756 & Hypothetical protein [Vitis vinifera] & $2 \times 10^{-22}$ & CR, PBB, FT \\
\hline ppb012876m & GR410653 & 1 & EEF42354 & Conserved hypothetical protein [Ricinus communis] & $3 \times 10^{-38}$ & $\mathrm{CR}, \mathrm{PBB}$ \\
\hline Not found & JK006311 & 1 & & & & $\mathrm{PBB}$ \\
\hline
\end{tabular}


Transcripts accumulated in buds after dormancy release are shown in Table 3.3. The transcript models of ppa020321m and ppa008309m, encoding peroxidase-like proteins, were the most represented genes in the experiment, with 69 and 27 ESTs respectively. Up-regulation of these and other related peroxidase genes has been reported in non-dormant buds of peach (Leida et al., 2010), coincidently with bud-break induced by chilling accumulation in Vitis riparia (Mathiason et al., 2009), and during dormancy release in leafy spurge (Jia et al., 2006). Peroxidases have been proposed to counteract the production of $\mathrm{H}_{2} \mathrm{O}_{2}$, a signal molecule exerting a dormancy breaking effect in grapevine buds and $A$. thaliana seeds (Pérez et al., 2008; Liu et al., 2010). Other transcripts related to dormancy release in Table 3.3 coded for putative lipid-transfer proteins (ppa020886m, ppa018509m, ppa025857 and ppa021109m), peptidases (ppa017856m, ppa014645m and ppa010924m), and dehydration-responsive proteins (ppa005535m, ppa005767m, ppa006739m and ppa020936m).

\section{Real-time PCR validation of microarray data}

Several genes selected from Tables 3.2 and 3.3 were analyzed by quantitative real-time RT-PCR using bud samples after $400 \mathrm{CH}$ (Figure 3.4). Genes from the tandemly repeated family of MADS box transcription factors DAM4, 5 and 6 showed a pattern of higher expression in 'Rose Diamond' and 'Big Top' cultivars, and lower expression in early cultivars, with maximum differences of about 100 fold. Genes ppa008651m, ppa012373m, ppa006974m, ppa007606m, ppa009498m and ppa012188m, listed in the Table 3.2 of dormancy-related transcripts, showed an expression profile similar to the $D A M$ genes, but with much lower differences between cultivars. Five of these genes showed a slightly higher expression level in 'Flor Red' and 'Precocinho' compared to other cultivars with proximate dormancy behaviour.

The most striking feature of transcripts associated to dormancy release in Table 3.3 is their almost null expression in the late varieties 'Rose Diamond' and 'Big Top' (Figure 3.4). Interestingly, three of these genes (ppa020886m, ppa018509m and ppa008548m) showed a specific pattern of overexpression in 'Red Candem', '86-6' and 'Sunraycer', resembling cultivar-specific alterations described above for five dormancy-related genes, which supports an involvement of common transcription regulatory mechanisms in case of a subset of genes. 


\section{DAM6 expression decreases concomitantly with dormancy release}

DAM proteins are the major known regulatory factors of bud dormancy processes, based on the analysis in the evg mutant of peach and different genomic studies in other species (Bielenberg et al., 2008; Horvath et al., 2008). From the six DAM genes, we chose DAM6 for subsequent expression analysis due to its recurrent identification in peach-dormancy genomic approaches (Jiménez et al., 2010a; Leida et al., 2010), and a close correlation of its expression with dormancy release and bud break found by Jiménez et al. (2010b), Yamane et al. (2011), and in this work.
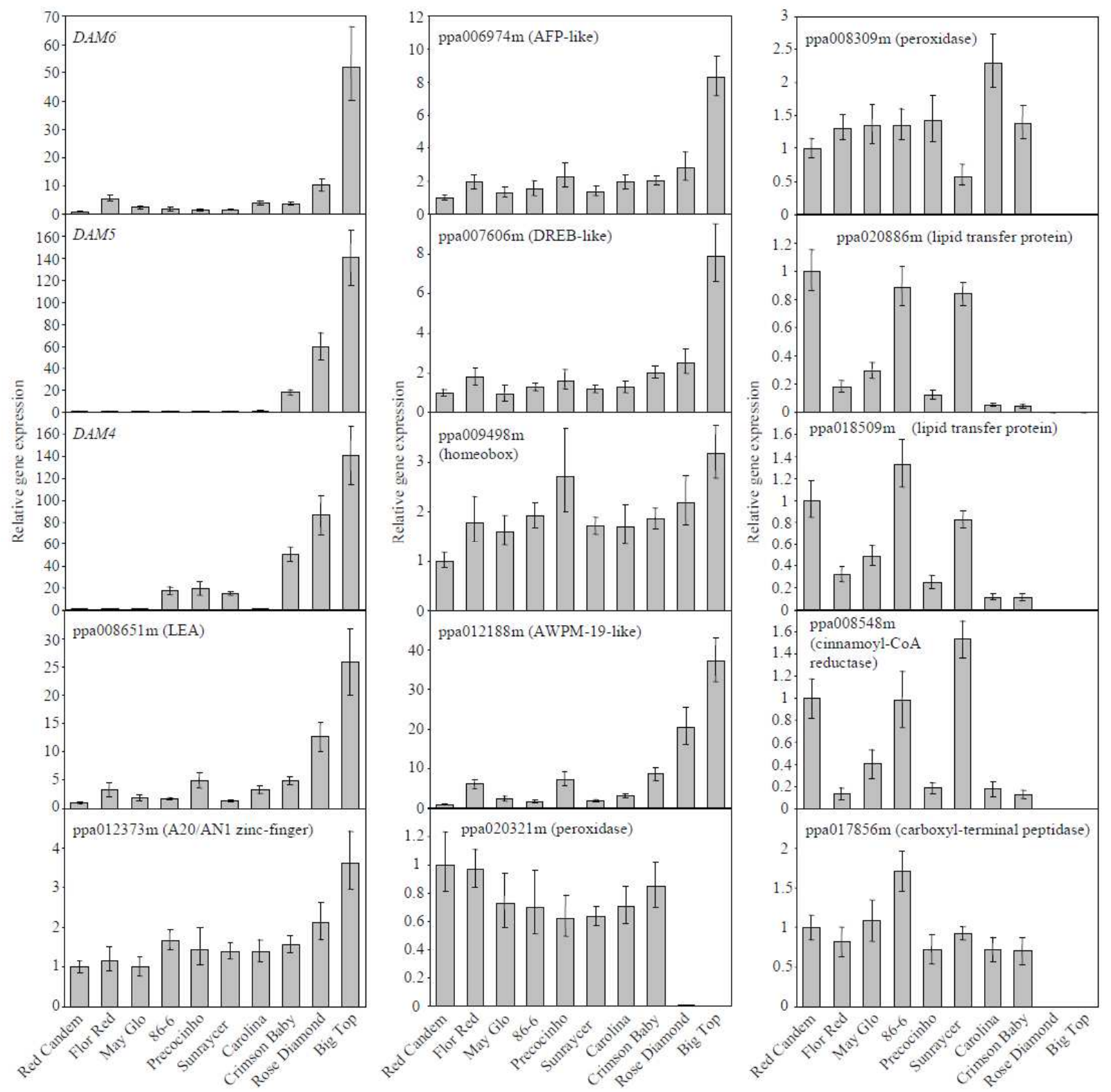

Figure 3.4. Real-time RT-PCR of selected genes. RNA samples were obtained from flower buds harvested after 400 chilling hours $(\mathrm{CH})$. The name of the gene or transcript model is shown in the upper left corner of the graph. Expression levels are relative to actin. An expression value of one is assigned to the 'Red Candem' sample. Data are means from two biological replicates, with error bars representing standard deviations. 
We measured DAM6 expression in two representative cultivars of early ('Red Candem') and relatively late ('Big Top') cultivars at different dates during bud dormancy release. In both cultivars, DAM6 transcript level was strongly reduced coincidently with a rise in growth competence of flower buds measured in the bud break assay (Figure 3.5a,b). Due to their distinct behaviour with respect to dormancy, such bud growth competence occurred after very different periods of chilling accumulation, $276 \mathrm{CH}$ for 'Red Candem' and $684 \mathrm{CH}$ for 'Big Top'. Thus, in agreement with previous works, DAM6 expression was correlating well with the dormancy release stage of two different cultivars. An expression peak was observed in 'Red Candem' after $50 \mathrm{CH}$, which could be due to the combination of light and chilling effects, following a peaked pattern similar to semi-quantitative measurements of DAM6 expression in Li et al. (2009).

\section{H3K4me3 and acetylated $\mathrm{H3}$ around the translation start of DAM6 decrease during gene repression and dormancy release}

We conducted a ChIP assay in order to define histone modifications of DAM6 chromatin during dormancy release. Three genomic fragments corresponding to DAM6 promoter ('PR'), the translation start site ('ST'), and a region of second large intron ('IN') were selected for ChIP analysis (Figure 3.5c) using 'Big Top' and 'Red Candem' bud samples shown in Figure 3.5(a,b). Real-time quantitative PCR data were standardized to histone H3 levels to calculate the relative ratio of modified $\mathrm{H} 3$ shown in Figure 3.5(d,e).

$\mathrm{H} 3 \mathrm{~K} 4 \mathrm{me} 3$ was in general more abundant in the 'ST' region than the upstream promoter and downstream intron in both cultivars, suggesting that the zone around the translational start could be susceptible to regulation (Figure 3.5d,e). Indeed, H3K4me3 was reduced in 'Big Top' buds in parallel to dormancy release in two independent experiments, reproducing accurately DAM6 downregulation shown in Figure 3.5(a). A significantly lower rate of H3K4me3 in 'Red Candem' after $276 \mathrm{CH}$ (RC4; Figure 3.5e) was also coincident with a lower expression level of the gene and the concomitant end of bud dormancy measured as bud break competence (Figure 3.5b). The rise in DAM6 expression observed after $50 \mathrm{CH}(\mathrm{RC} 2)$ was however not accompanied by a corresponding increase in $\mathrm{H} 3 \mathrm{~K} 4 \mathrm{me} 3$. This discrepancy could be due to the presence of a yet unknown chromatin modification contributing to gene expression, the binding of a transcriptional activator, or alternatively could have a posttranscriptional origin, as a differential rate of mRNA degradation.

$\mathrm{H} 3 \mathrm{ac}$ was found around the 'ST' region during dormancy progression of 'Big Top' and 'Red Candem' samples (Figure 3.5d,e). In 'Big Top' a significant reduction of H3ac level occurred in 
BT3, a dormant sample previous to dormancy release, but no events timing could be established in 'Red Candem' due to certain discrepancies in the decreasing pattern observed between independent experiments.

Similar results were observed when measuring the relative level of $\mathrm{H} 3$ acetylation (H3ac). H3ac was not consistently regulated during bud development in 'PR' and 'IN' fragments, but a significant decrease in $\mathrm{H} 3 \mathrm{ac}$ level occurred in BT3, a dormant sample before dormancy release, but no events timing could be established in 'Red Candem' because of certain discrepancies in the decreasing pattern observed between independent experiments.

\section{H3K27me3 increases along DAM6 gene after dormancy release}

H3K27me3 followed an opposite pattern to H3K4me3 and H3ac modifications. A relevant accumulation of H3K27me3 was only detected in the last 'Big Top' sample (BT5), when buds had already passed the dormancy period (Figure 3.5d). Interestingly, H3K27me3 occurred to a similar extent in the three genomic regions of DAM6, that supports the overall gene modification rather than the modulation of a short regulatory element. A certain increase of H3K27me3 was noted in the non-dormant RC4 sample of 'Red Candem', but this alteration was not significant and about 10fold lower than in BT5 (Figure 3.5e). Consequently, H3K27me3 modification, unlike H3K4me3 and $\mathrm{H} 3 \mathrm{ac}$, correlated positively with bud break competence following the dormancy period in a cultivar-dependent manner, and showed a wide distribution along DAM6 gene.

Collectively, these results emphasize the occurrence of specific chromatin histone modifications in the DAM6 gene during bud dormancy progression and release, and offer a plausible mechanism for the transcriptional regulation of this relevant gene in dormancy processes. 
(a)

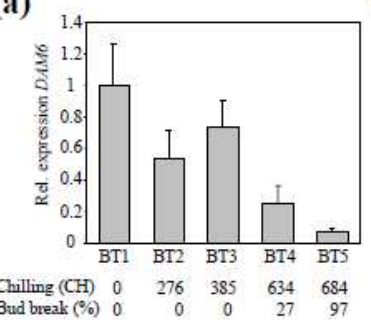

(b)

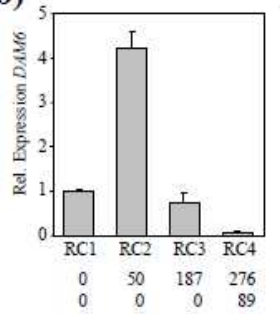

(c)

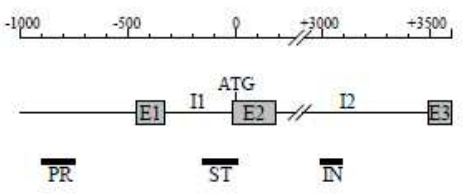

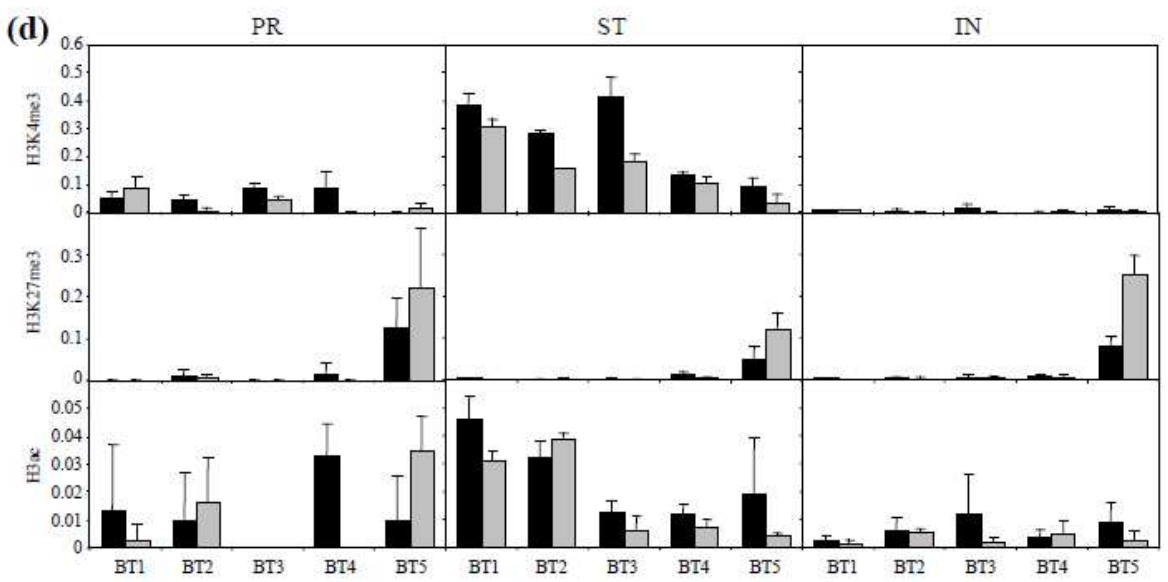

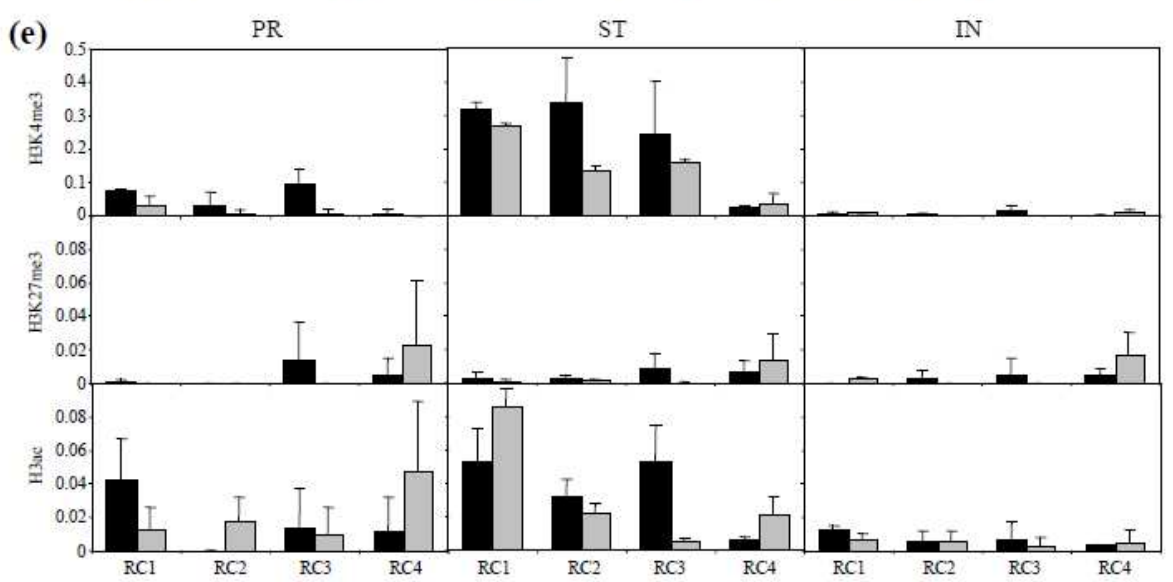

Figure 3.5. Chromatin immunoprecipitation (ChIP) analysis of DAM6 gene during dormancy progression. Relative expression of DAM6 by real-time RT-PCR in the late 'Big Top' (a) and the early 'Red Candem' (b) cultivars. Flower bud samples of 'Big Top' (BT1-5) and 'Red Candem' (RC1-4) were collected at different chilling exposure times or chilling hours $(\mathrm{CH})$, as shown in the lower part of the figure. The dormancy stage of these buds was assessed by measuring the percentage of bud break, which is also shown. Expression values are relative to actin and to the first sample (BT1 or RC1). Data are means from two biological replicates repeated twice, with error bars representing standard deviations. A diagram showing the localization of three fragments on the promoter (PR), translation start (ST) and second large intron (IN) of DAM6 gene, employed in the ChIP experiment, is depicted (c). The first three exons (E1-3, grey boxes) and the first two introns of the gene are shown. The gene diagram and the corresponding ATG-centered base-pair scale are discontinued on the second intron. Quantification of histone modifications in PR, ST and IN fragments was performed by real-time PCR subsequently to ChIP in the 'Big Top' (d) and 'Red Candem' (e) samples. The levels of H3K4me3, $\mathrm{H} 3 \mathrm{~K} 27 \mathrm{me}$, and H3ac are normalized for histone H3 occupancy. Two independent ChIP experiments starting with biological replicates were performed (black and grey bars). Data are means from three replicates, with error bars representing standard deviations. 


\section{Discussion}

\section{Complementary transcriptomic approaches find $D A M$ genes related to bud dormancy establishment and release}

The aim of this work was to identify peach genes whose expression in flower buds at a single developmental stage $(400 \mathrm{CH})$ correlated with the chilling requirement and other dormancy variables of ten different cultivars. Previous studies employed the SSH procedure for the isolation of bud dormancy-related genes in peach. Jiménez et al. (2010a) used SSH to compare wild type and evg mutant gene expression after bud growth cessation mediated by transfer to short day conditions. From 23 genes found by Jiménez and coworkers, only one (DAM6) has been also obtained in this work, most likely due to differences in the experimental design. Whereas Jiménez and colleagues examined dormancy entrance by modulating photoperiodic conditions, our work is mostly devoted to dormancy break processes based on cultivar diversity. Thus, the identification of DAM6 in both studies confers an increasing interest to this gene.

On the other hand, Leida et al. (2010) employed SSH to identify genes associated to bud dormancy release processes, which served to design the microarray used in this work. In spite of the experimental differences between both approaches, the number of coincidences with our work is higher in this case (25). The set of common genes includes three members of the DAM family (DAM4-6), and genes coding for a LEA, a Zn-finger protein, peroxidases, lipid transfer proteins and peptidases among others. The percentage of cDNAs correlating with cultivar-specific differences may seem unexpectedly low if we consider that microarray probes were obtained by subtractive hybridization of dormant versus non-dormant samples, however previous results show that the ratio of genuine differentially expressed clones after SSH may be very low, and an additional validation step is required in most cases (Yamane et al., 2008; Leida et al., 2010).

The role of DAM transcription factors in regulating bud dormancy entrance and release in peach is not only supported by transcriptomic analyses, but also by expression data (Jiménez et al., 2010b; Yamane et al., 2011), and genetic studies. A deletion of several DAM genes was tightly linked to the non-dormant and defective terminal bud formation phenotype of the evg mutant (Bielenberg et al., 2008). In addition, quantitative trait loci (QTL) mapping of chilling requirement, heat requirement and bloom date in peach led to a major QTL in linkage group 1, overlapping with the EVG locus containing DAM genes (Fan et al., 2010). Thus, in agreement with our results DAM factors are consequently considered the main candidates to control bud dormancy and meristem 
growth cessation, through regulation of gene expression, in peach and other perennial plants. DAM4-6 and other genes found in this work could be employed as expression markers for comparing the chilling requirements and dormancy aptitudes of different cultivars. In our opinion, a single time RT-PCR assay using few genes could facilitate the phenotypic evaluation of large collections of individuals, as the segregating population of a cross for plant breeding purposes.

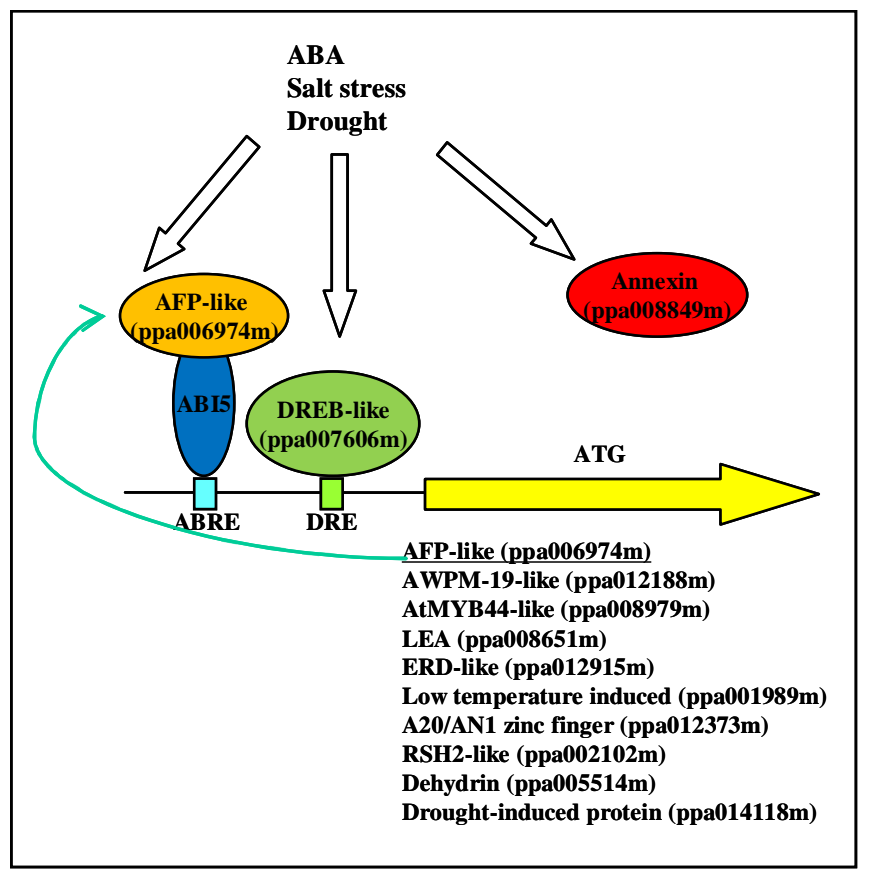

Figure 3.6. ABA and drought related proteins. White arrows symbolize the transduction of $\mathrm{ABA}$ and abiotic stress signals. White boxes represent ABRE and DRE elements on the promoter of $\mathrm{ABA}$ and drought responsive genes. Proteins coded by genes responding to these signals are located below the filled arrow. The transcript models of genes described in this work are shown in parentheses.

\section{ABA and drought responding genes are dormancy regulated}

It is remarkable that many genes expressed in dormant buds correspond to ABA and drought-related genes in other species. On this matter, Figure 3.6 lists some proteins identified in this work with homologues described as inducible by abiotic stresses or ABA. One of these proteins encoded by ppa006974m is similar to ABA-INSENSITIVE5 (ABI5) binding protein (AFP), involved in ABA signal transduction in A. thaliana. AFP binds to and promotes proteolytic degradation of ABI5, a basic leucine zipper (bZIP) transcription factor that regulates ABA-dependent genes by binding to the ABA-responsive element, ABRE (López-Molina et al., 2003). In addition to ABRE, abiotic stresses affect gene expression through the dehydration-responsive element (DRE) and their respective DRE binding proteins (DREB; Liu et al., 1998). The transcript model ppa007606m found in this work encodes a DREB-like factor that could contribute to the dormancy-specific expression of $\mathrm{ABA}$ and drought responsive genes. On the other hand, calcium-binding annexins 
related to the product of ppa008849m have been found involved in ABA and osmotic stress signal transduction in A. thaliana (Lee et al., 2004).

These observations are in agreement with recent findings by Jiménez et al. (2010a), showing that genes encoding a LEA and KEEP ON GOING (KEG)-like proteins are misregulated in evg mutant during short day induction of bud dormancy. KEG is an E3 ligase which regulates ABI5 abundance by means of its ubiquitination and subsequent proteasome-mediated degradation in A. thaliana (Stone et al., 2006).

ABA has been proposed for long time to promote and maintain bud dormancy, although only few consistent molecular data support this prediction (Arora et al., 2003; Horvath et al., 2003; Rohde \& Bhalerao, 2007). More relevantly, the poplar homologue of A. thaliana ABSCISIC ACID INSENSITIVE 3 (ABI3) gene was found expressed in buds during bud set, coinciding with an increase in ABA content (Rohde et al., 2002). Moreover, overexpression and down-regulation of PtABI3 in poplar caused developmental alterations in bud formation and misregulation of numerous genes during bud induction and dormancy (Ruttink et al., 2007). In a recent work, ectopic expression of the A. thaliana mutant abscisic acid insensitive 1 (abil) gene in poplar was shown to modify the dormancy response of lateral buds to exogenous ABA (Arend et al., 2009).

Some of the proteins shown in Figure 3.6 could contribute to cold hardening processes improving frost tolerance of buds. Interestingly, overexpression of AtMYB44 (Jung et al., 2008), rice A20/AN1 zinc-finger protein (Mukhopadhyay et al., 2004), and A. thaliana DREB2C gene similar to ppa007606m (Lee et al., 2010) conferred tolerance to cold or freezing temperatures in transgenic plants. In addition, dehydrins and AWPM-19-like plasma membrane proteins have been associated to cold tolerance in peach and wheat respectively (Artlip et al., 1997; Koike et al., 1997). In conclusion, our results support a role of $\mathrm{ABA}$ and drought responses in bud dormancy and cold acclimation processes, and contribute to identify several genes encoding putative regulatory factors of these pathways in peach.

\section{DAM6 is regulated at the chromatin level}

The chromatin modifications H3K4me3, H3ac and H3K27me3 had a different timing for 'Big Top' and 'Red Candem', coinciding with their specific patterns of gene repression and increase in bud break competence. This argues for a potential role of chromatin modification in modulating DAM6 expression and subsequently the state of bud dormancy. Nevertheless, H3K27me3 was not significantly increased in the 'Red Candem' buds just after dormancy release (RC4), which in fact 
suggests a sequential chain of molecular events affecting the local state of DAM6 chromatin as outlined in Figure 3.7. In dormant buds (BT1 and RC1 samples), transcriptionally active DAM6 gene would contain $\mathrm{H} 3 \mathrm{~K} 4 \mathrm{me} 3$ and $\mathrm{H} 3 \mathrm{ac}$ in a short chromatin region around its ATG (Figure 3.7a). Following demethylation of $\mathrm{H} 3 \mathrm{~K} 4$ and deacetylation of $\mathrm{H} 3$, DAM6 repression would contribute to release dormancy in samples BT4/BT5 and RC4 (Figure 3.7b). Finally, H3K27me3 in a region of at least $4 \mathrm{~Kb}$ including promoter, coding sequence and introns, would mediate stable epigenetic repression of the gene through subsequent cell cycles (Figure 3.7c). This last stage corresponds to the BT5 sample, but does not have a 'Red Candem' counterpart in this work, which in fact confirms the temporal separation of $\mathrm{H} 3 \mathrm{~K} 4 \mathrm{me} 3$ and $\mathrm{H} 3 \mathrm{ac}$ events from $\mathrm{H} 3 \mathrm{~K} 27 \mathrm{me} 3$. Two scenarios are possible in 'Red Candem' after the induction stage detected in RC4: i) DAM6 chromatin is not trimethylated on $\mathrm{H} 3 \mathrm{~K} 27$, which could in fact contribute to cultivar specific differences in dormancy response, and ii) $\mathrm{H} 3 \mathrm{~K} 27$ trimethylation occurs in a subsequent step, and thus phenotypic differences between cultivars could simply depend on the distinct chilling time required for triggering the whole process.

Figure 3.7. Possible sequence of DAM6 chromatin events during dormancy release. In dormant buds, transcriptionally active DAM6 has $\mathrm{H} 3 \mathrm{~K} 4 \mathrm{me} 3$ and $\mathrm{H} 3 \mathrm{ac}$ modifications around the translation start region (a). Buds undergoing dormancy release lose $\mathrm{H} 3 \mathrm{~K} 4 \mathrm{me} 3$ and $\mathrm{H} 3 \mathrm{ac}$ modifications concomitantly with gene repression (b), as observed in 'Red Candem' cultivar. Finally, overall H3K27me3 modification could facilitate long-term gene inactivation (c). (a)

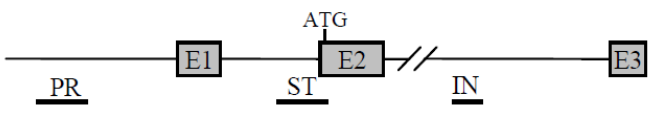

(b)

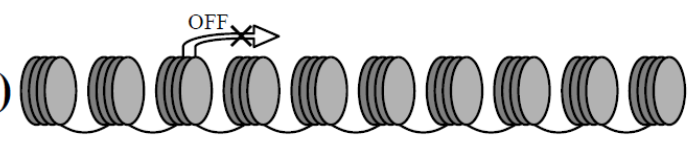

(c)

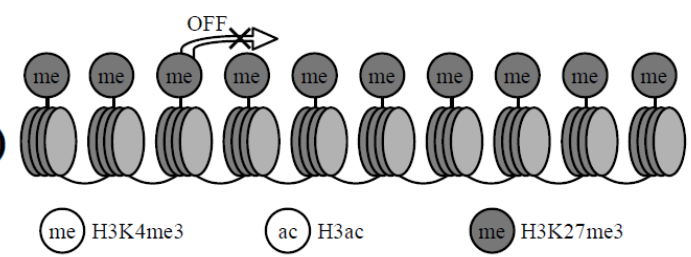

Changes in the methylation state of $\mathrm{H} 3 \mathrm{~K} 27$ and $\mathrm{H} 3 \mathrm{~K} 4$ have been recently observed in the promoter of DAM1 gene of leafy spurge when comparing buds in different dormancy stages (Horvath et al., 2010). These chromatin modifications have been related to the down-regulation of DAM1, as observed for DAM6 in this work. Both genes encode MIKC ${ }^{\mathrm{c}}$-type MADS-box proteins belonging to the SVP/StMADS11 clade (Becker \& Theißen, 2003; Jiménez et al., 2009; Horvath et al., 2010), but are not strictly orthologous. Leafy spurge $D A M 1$ is more similar to the peach transcript 
ppa022274m, which has not been related to dormancy processes. They may have been originated in an ancestral duplication event followed by a functional diversification.

Modification of DAM6 chromatin in a similar way to FLC and VRN1, as a consequence of the prolonged exposure to low temperatures (Bastow et al., 2004; Sung \& Amasino, 2004; Oliver et al., 2009), confirms the existence of mechanistic similarities between vernalization and bud dormancy processes. The coincidence of $\mathrm{H} 3 \mathrm{~K} 27 \mathrm{me} 3$ and gene repression in these three models suggests the common concurrence of methyl-transferases activities associated to related PcG multi-protein complexes in FLC, VRN1 and DAM6. Thus, PcG complexes are potentially responsible for the stable repression of DAM6 at the end of the seasonal dormancy until the next period of bud formation, which would require yet unknown mechanisms of DAM6 activation for the initiation of a new dormancy cycle. Additional genetic and biochemical approaches are required to identify these and other regulatory elements implicated in DAM-dependent pathway.

\section{Supporting Information}

Table S3.1 Analysis of correlation for the variables chilling requirement, flowering time, percentage of bud break.

Table S3.2. Accession numbers of ESTs.

Table S3.3. List of primers used in this work.

This material is contained in the CD annexed to this thesis. 



\section{Gene expression analysis of chilling requirements for flower bud break in peach}

This work was accepted in Plant Breeding:

Leida C., Romeu J.F., García-Brunton J., Ríos G., Badenes M.L. 2012. Gene expression analysis of chilling requirements for flower bud break in peach. Plant Breeding (in press). 



\begin{abstract}
Dormancy has been defined as the inability to initiate growth from meristem under favourable environmental conditions. The length of dormancy is a genotype-specific trait that limits the climatic adaptability of temperate crops, as peach. A better knowledge of the genes involved in dormancy may provide genetic tools for an early assessment of the trait in breeding programs. Recent studies on the molecular aspects of dormancy provided an initial description of candidate genes involved in bud dormancy maintenance and release in peach. In this paper, we compare the chilling requirement for dormancy release of five peach cultivars with the expression of five genes and ESTs related to bud dormancy: DAM5, DB396 (ppa007606m), DB247 (ppa012188m), SB280 (ppa006974m) and PpB63 (ppa008309m). Results indicated that gene expression analysis could contribute to estimate the chilling requirement for dormancy release of new cultivars.
\end{abstract}

\title{
Introduction
}

Dormancy has been defined as the inability to initiate growth from meristem under favourable conditions (Rohde \& Bhalerao, 2007). Perennial plants have developed a dormancy mechanism that ensures the survival of meristems in specific structures (buds) during the low temperatures of winter. Bud dormancy is only released after exposure to a prolonged period of cold, which helps avoid freezing injury of actively growing tissues. The length of cold exposure required by a particular genotype is quantitative and heritable (Hauagge \& Cummins, 1991; Fan et al., 2010). Incomplete fulfilment of this quantitative chilling requirement may lead to bud break delay (Murray et al., 1989, Heide 1993), and irregular floral and vegetative development (Coville 1920; Erez et al., 1979; Erez \& Couvillon, 1987; Oukabli \& Mahhou, 2007; Topp et al., 2008), with a subsequent reduction in yield. Consequently, chilling requirement is an adaptive genetic trait that restricts fruit production to specific climatic zones, and thus has become an important objective in different plant breeding initiatives worldwide (Monet \& Bassi, 2008). In peach, chilling requirements and dormancy duration are specific for each cultivar (Ruiz et al., 2007; Viti et al., 2010). The introduction of germplasm with less chilling requirements for dormancy release has expanded the growing area of this species to mild-winter climates and has increased the fruit harvest period, allowing more competitive prices. Interest in low chill requiring varieties in a wide range of perennial species has increased due to the onset of climatic warming (Topp et al., 2008; Luedeling et al., 2011). 
Several empirical models for chilling requirement fulfilment have been developed. These models differ in the effective temperatures for chilling fulfilment and the possible negation of chilling accumulation by warm temperatures. Three models are most widely used. The Weinberger considers temperatures below $7^{\circ} \mathrm{C}$ as equally effective in chilling fulfilment (Weinberger 1950). The Utah model has a narrow range of effective temperatures $\left(3^{\circ} \mathrm{C}\right.$ to $\left.9^{\circ} \mathrm{C}\right)$ and assigns negative values to temperatures higher than $16^{\circ} \mathrm{C}$ and lower than $0^{\circ} \mathrm{C}$ (Richardson et al., 1974). Finally, the Dynamic model developed by Fishman et al. (1987a, 1987b), introduces the effect of different temperature cycles and weighted effective temperatures, based on studies developed by Erez and collaborators (Erez et al., 1979; Couvillon \& Erez, 1985; Erez \& Couvillon, 1987). While these models tend to agree in relatively cold winter climates, they vary widely in warm winter climates. Assignment of a chilling requirement to a given genotype is made by repeated sampling of cuttings throughout the winter. The cuttings are then incubated at growth conducive temperatures and evaluated for bud break. The accumulated chilling exposure determined by one of the above models at the sampling date where a threshold of bud break occurs is then considered to be the chilling requirement of that specific genotype. Unfortunately, these procedures are costly and timeconsuming when analyzing a large number of genotypes, and the reliability depends on environmental conditions, showing wide variations during consecutive years (Balandier et al., 1993). From a practical point of view, plant breeding programs that need to determine chilling requirements of a large number of genotypes simplify the phenotyping by only measuring bloom date as an indicator of dormancy release. Unfortunately this introduces additional variables in the assessment such as the genetic variation of heat requirement for bud break (Topp et al., 2008).

A better knowledge of dormancy processes at the physiological and genetic level may provide key information for an early assessment of chilling requirement. Several reviews highlight the role of external (day-length shorteningand temperature) and endogenous factors (growth regulators, cell cycle regulation, water status and chromatin modification) as regulators of bud dormancy onset and release (Arora et al., 2003; Horvath et al., 2003; Baurle \& Dean, 2006; Rohde \& Bhalerao, 2007; Allona et al., 2008).

Mapping of bud dormancy variables in Prunus species has been approached by QTL analysis in almond (Sánchez-Pérez et al, 2007), apricot (Olukolu et al., 2009) and peach (Fan et al., 2010). Interestingly, the major QTLs located in linkage groups 1, 5 and 7 were common to apricot and peach. On the other hand, the trait 'blooming date' has been mapped in linkage group 4 in almond (Sánchez-Pérez et al., 2007). 
Undoubtedly, the characterization of the peach non-dormant mutant evergrowing (evg), carrying a deletion affecting several members of a family of six tandem repeated MADS-box genes, named DAM1-6 (DORMANCY ASSOCIATED MADS-BOX), represented a valuable tool for genetic and molecular assessment of growth cessation and dormancy processes (Bielenberg et al., 2004, Bielenberg et al., 2008). Furthermore, the EVG genomic region coincided with the major QTL mapped for chilling requirement (Fan et al, 2010). Consequently, DAM genes are considered major candidates to control bud dormancy and meristem growth cessation. However the dormancy trait is a complex character linked to many biochemical processes and further studies are needed. Recent studies on the molecular aspects of dormancy gave an initial description of additional candidate genes involved in bud dormancy maintenance or release in raspberry, grapevine, peach and apricot (Bassett et al., 2006; Mazzitelli et al., 2007; Yamane et al., 2008; Mathiason et al., 2009; Leida et al., 2010).

In this paper we evaluate the chilling requirements for dormancy release of five peach cultivars by applying the Weinberger, Utah and Dynamic models, and study the differential expression of five genes and ESTs related to dormancy processes: DAM5, DB396 (peach transcript ppa007606m), DB247 (ppa012188m), SB280 (ppa006974m) and PpB63 (ppa008309m) (Bielenberg et al., 2004; Leida et al., 2010; 2011). Finally we discuss the usefulness of relative gene expression analysis as a tool for assisting in the evaluation of the chilling requirement of peach varieties in breeding programs.

\section{Materials and Methods}

\section{Plant material}

The plant material consisted of five peach cultivars differing in chilling requirements: 'Big Top', 'Catherina', 'Fergold', 'Maruja' and 'Springlady'. The plants were grown in Murcia region (37 59' $\left.\mathrm{N}-1^{\circ} 07^{\prime} \mathrm{W}\right)$ at IMIDA experimental fields, located in four different locations. The plot consisted in a collection of varieties planted at $4 \times 4 \mathrm{~m}$ that received standard cultural practices. Data were obtained from three trees per cultivar.

\section{Quantification of chilling requirements}

Flower bud break was determined weekly from October 2009 to February 2010 using a shoot cutting test. Thirty one-year old shoots of 25 to $40 \mathrm{~cm}$ in length were harvested weekly from each 
cultivar and grouped into three sets of ten shoots, placed in bottles containing distilled water with $3 \%$ sucrose and incubated in a growth chamber with a $12 \mathrm{~h}$ photoperiod and $22^{\circ} \mathrm{C}$ constant temperature. The basal $1 \mathrm{~cm}$ of shoots were cut back and the water renewed twice per week to prevent disease development. After 10 days, we scored the number of buds that reached the green stage (stage C) according to the Baggiolini code (Baggiolini 1980). The percentage of bud break was calculated for each sampling date and a variety was classified as non-dormant when $25 \%$ of flowering buds were at stage $\mathrm{C}$.

Air temperatures experienced by the five varieties in the field were recorded from the beginning of November until the end of April at the SIAM (Murcia Agriculture Information System, www.siam.es) weather station, located at the experimental plot. The air temperature data was used to calculate the accumulated chill hours (Weinberger 1950), chill units (Utah model, Richardson et al., 1974) and chill portions (Dynamic model, Fishman et al., 1987a; 1987b) at each shoot sampling date. Each variety was assigned a chill hour, chill unit, and chill portion value based upon the sampling date at which the variety reached the $25 \%$ bud break threshold.

\section{Measurement of the expression of selected genes by quantitative real-time RT-PCR}

Flower buds were sampled when they accumulated 400 chilling hours according to Weinberger model, which were reached from $18^{\text {th }}$ December 2009 to $11^{\text {th }}$ February 2010. Plant material was stored at $-80^{\circ} \mathrm{C}$ until RNA isolation. Total RNA was isolated from approximately $100 \mathrm{mg}$ of bud tissue with the RNeasy mini kit (Qiagen, Valencia, CA, USA) following manufacturer's instructions but with the addition of $1 \% \mathrm{PVP}(\mathrm{w} / \mathrm{v})$ to the extraction buffer. Approximately three $\mu \mathrm{g}$ of total RNA was reverse transcribed with the SuperScript III First Strand Synthesis System for RTPCR (Invitrogen, Carlsbad, CA, USA) in a total volume of $20 \mu$ l. One microlitre of a 10× diluted first strand cDNA was used for each amplification reaction in a final volume of $20 \mu$ l. Quantitative real-time PCR was performed on a StepOnePlus ${ }^{\mathrm{TM}}$ Real-Time PCR system (Applied Biosystems, Foster City, CA, USA), using PerfeCta ${ }^{\mathrm{TM}} \mathrm{SYBR}^{\circledR}$ Green SuperMix ROX (Quanta Biosciences, Gaithersburg, MD, USA) following the manufacturer's instructions. Primer pairs used are listed in Table 4.1. 
The cycling protocol consisted of $10 \mathrm{~min}$ at $95^{\circ} \mathrm{C}$, followed by 40 cycles of $15 \mathrm{~s}$ at $95^{\circ} \mathrm{C}$ for denaturation and $60 \mathrm{~s}$ at $60^{\circ} \mathrm{C}$ for annealing and extension. Specificity of the reaction was assessed by the presence of a single peak in the melting curve after the amplification and through size estimation of the amplified product on a $1 \%$ agarose gel. The comparative $C_{T}\left(\Delta \Delta C_{T}\right)$ method was used to estimate cDNA abundance and the standard curve regression was applied when amplification efficiencies were not equivalent to that of the reference actin gene. Results were the average of two independent biological replicates repeated three times.

Table 4.1. Primers employed in the quantitative RT-PCR.

\begin{tabular}{|c|c|c|}
\hline & Primer sequence forward $\left(5^{\prime}-3^{\prime}\right)$ & Primer sequence reverse $\left(5^{\prime}-3^{\prime}\right)$ \\
\hline Actin & CAGATCATGTTTGAGACCTTCAATGT & CATCACCAGAGTCCAGCACAAT \\
\hline DAM5 & CCACATCAAACTGAGTAAGGAACTC & CTGCCTTAGCTGGTTGTTAGCTTCAACT \\
\hline DB396 & TGAAGAGGGATGATGTTACTGGCGA & CACAAAATGACCAGACATGACAAGG \\
\hline DB247 & CCCAGCCAATATGGCGAATATCAGAA & CATAGTGAGCAGTAAGTTTGTGCT \\
\hline SB280 & TTCCGTTGGTGGTGGAGTGGATGCA & TTACTAGCAGGGCTTCTTGCTTCAC \\
\hline PpB63 & TCTCCCTTCGTCCCAGTAAATGGTC & TTTCTGGGGAGGGTTTGCTTCCATC \\
\hline
\end{tabular}

\section{Results}

\section{Chilling accumulation in field conditions}

The cultivars 'Catherina', 'Fergold' and 'Maruja' displayed higher chilling requirements, with values ranging between 800 and 1200 chilling units, 570 and 920 chilling hours, and 50 and 65 portions (Table 4.2). These cultivars were classified as 'high-chill'. 'Springlady' and 'Big Top' showed medium requirements with values ranging between 500 and 700 chilling units, 300 and 400 chilling hours, and 30 and 45 portions, and were considered as 'medium-chill' (Table 4.2).

A high correlation was observed for calculated effective chilling accumulation between Utah and Dynamic models $\left(\mathrm{R}^{2}=0.96\right)$, which supports the high similarity between both methods in Mediterranean mild winters (Figure 4.1). The Weinberger model showed lower correlation coefficients with both the Utah and Dynamic models, with $\mathrm{R}^{2}=0.77$ and 0.76 respectively (Figure 4.1). 
Table 4.2. Chilling requirement to overcome dormancy.

\begin{tabular}{ccccc}
\hline Cultivar & $\begin{array}{c}\text { Dormancy } \\
\text { breaking date }\end{array}$ & $\begin{array}{c}\text { Utah model } \\
\text { (chilling units) }\end{array}$ & $\begin{array}{c}\text { Weinberger model } \\
\text { (chilling hours) }\end{array}$ & $\begin{array}{c}\text { Dynamic model } \\
\text { (portions) }\end{array}$ \\
\hline 'Springlady' & $27^{\text {th }}$ January 2010 & 626 & 331 & 40.8 \\
'Big Top' & $2^{\text {nd }}$ February 2010 & 716 & 363 & 45.2 \\
'Maruja' & $10^{\text {th }}$ February 2010 & 809 & 572 & 51.8 \\
'Catherina' & $16^{\text {th }}$ February 2010 & 1220 & 793 & 62.4 \\
'Fergold' & $2^{\text {nd }}$ February 2010 & 861 & 921 & 52.8 \\
\hline
\end{tabular}
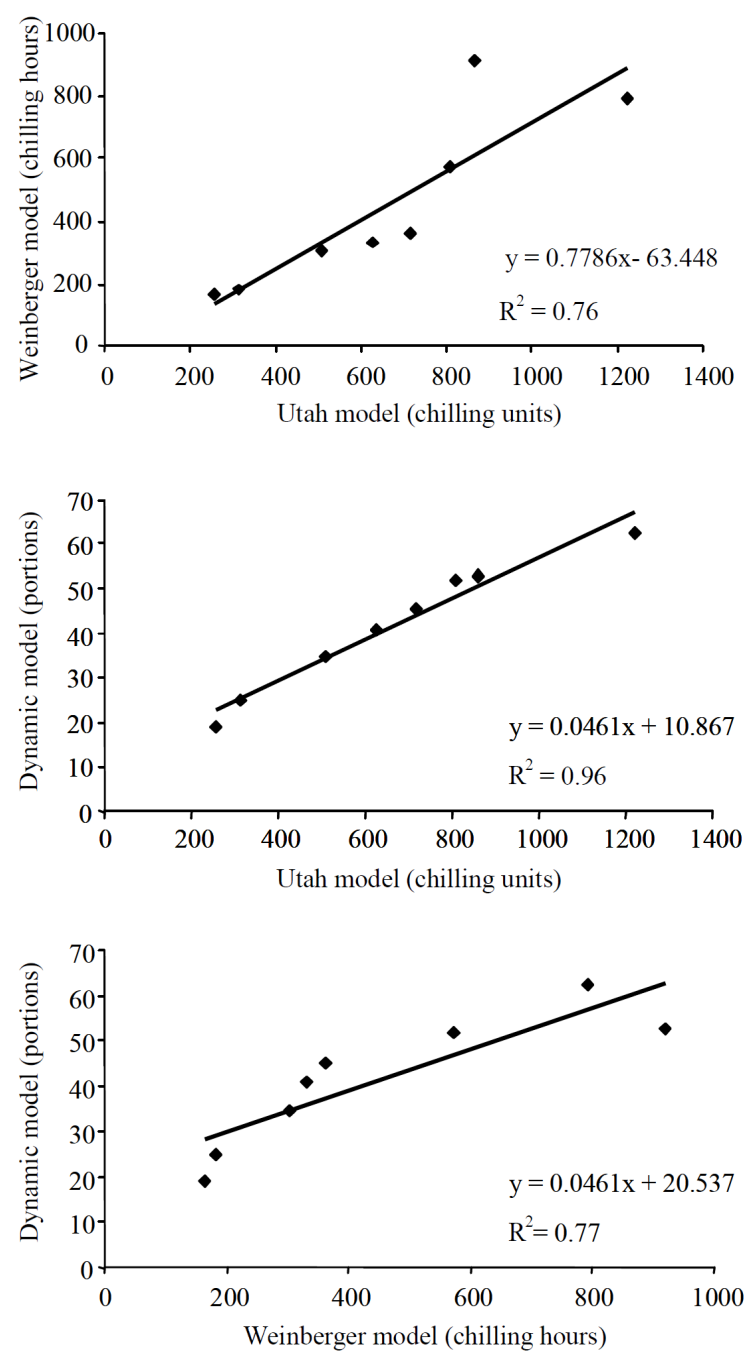

Figure 4.1 Correlations between the Weinberger, Utah, and Dynamic models for calculation of the chilling requirement for dormancy release. 


\section{Differential expression of genes related to dormancy release}

Five genes with expression profiles correlating with chilling fulfilment in previous studies were selected for expression analysis in this study (Li et al., 2009; Leida et al., 2010; 2012). DAM5 belongs to the cluster of $D A M$ genes that have been found deleted in the evg mutant and associated with the major QTL for bud dormancy in peach (Bielenberg et al., 2008; Fan et al., 2010). The protein encoded by EST DB396 has an AP2 DNA-binding domain found in transcriptional regulators such as APETALA2 and EREBP, an ethylene responsive element binding protein (Tacken et al., 2010). The product of EST DB247 is similar to a membrane protein that accumulates during induction of freezing tolerance in wheat (Koike et al., 1997). EST SB280 codes for a protein with homology to ABI5 binding protein from Arabidopsis thaliana, involved in abscisic acid signalling (Lopez-Molina et al., 2003). Finally, EST PpB63 codifies for a protein similar to a peroxidase described in cotton (Chen et al., 2009).

When expression of the above genes was analyzed at 400 chilling hours in the each of the five cultivars, two clear patterns emerged. DAM5, DB396, DB247 and SB280 were expressed at higher levels in the varieties with the highest chilling requirements while PpB63 was up-regulated in lowest chill requiring varieties (Figure 4.2).

The expression level of DAM5 was lower in 'Springlady' and 'Big Top' than in 'Maruja', 'Fergold' and 'Catherina' (Figure 4.2). DB247, SB280 and particularly DB396 were expressed at higher levels in 'Catherina', which showed respectively about 5, 2.5 and 15-fold higher transcript abundance than the other cultivars.

PpB63 gene expression was ten-fold higher in 'Springlady' than in 'Fergold', the cultivar with the lowest expression. This is in close agreement with published data showing a pattern of PpB63 accumulation at the end of dormancy (Leida et al., 2010), considering that at the sampling date (400 chilling hours) 'Springlady' had already fulfilled the chilling requirement for bud break. (Table 4.2). 


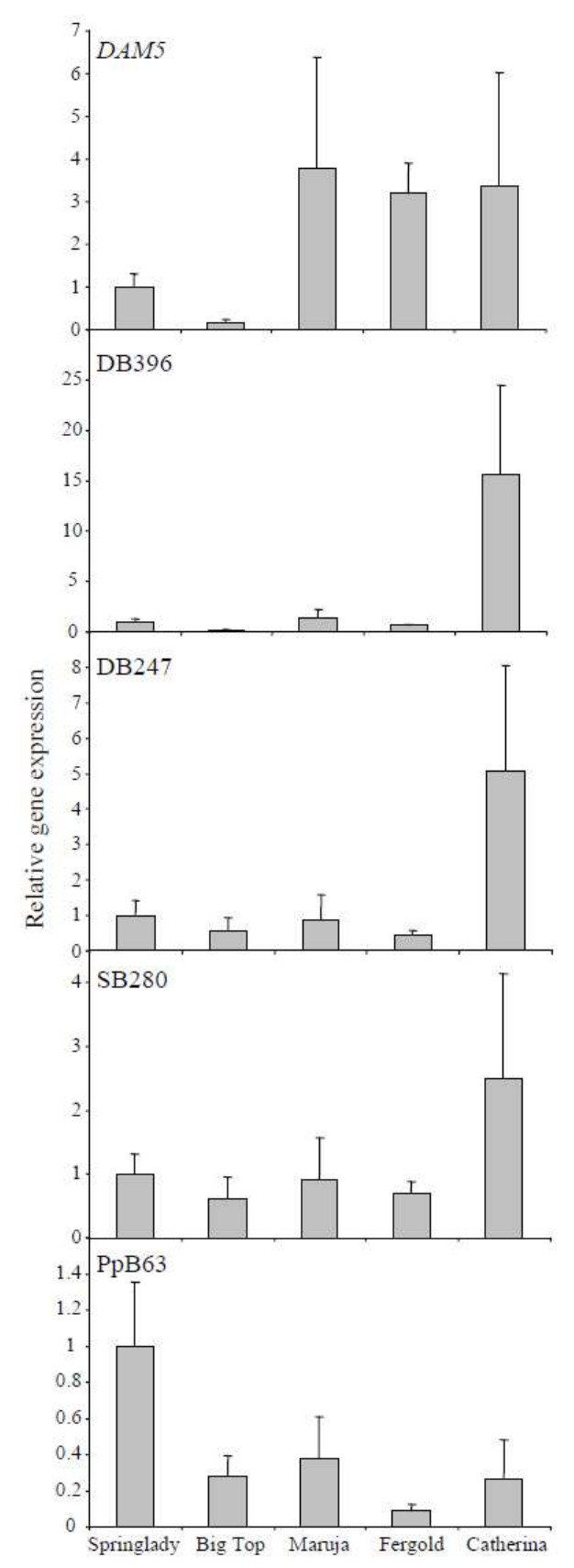

Figure 4.2 Quantitative real-time RT-PCR analysis of five genes related to dormancy. RNA samples were obtained from flower buds of 'Springlady', 'Big Top', 'Maruja', 'Fergold' and 'Catherina'. The cultivars are arranged by increasing chilling requirement in the graph. Expression levels are referred to Actin and a relative expression of one is assigned to 'Springlady'. Data are means of two biological replicates with error bars representing standard deviations.

\section{Discussion}

In peach, many cultivars are released every year. The description of new cultivars usually includes common pomological characteristics, but detailed information about chilling requirement is often absent, mainly due to the difficulties inherent to the measurement of dormancy variables. A method allowing the quick and accurate determination of chilling requirements and consequently providing 
information about the adaptability of a cultivar to a given environment would be very valuable. The current methods are based on indirect temperature measures with low reproducibility among areas with different climatic conditions. A comparative study between the three models in two different locations reported wide environmental and temporal variations (Balandier et al., 1993).

We have calculated the chilling requirement of selected cultivars using temperature models and compared them with results obtained in other areas by other authors. The inaccuracy of current methods is confirmed by the interval of values obtained for the same variety by different authors. For instance, Valentini et al. (2001) found chilling requirements for 'Springlady' that doubled the value determined in this study, and Okie (1998) reported for 'Springlady' and 'Catherina' 750 and $900 \mathrm{CU}$ respectively, much different than our measurements of 626 and $1220 \mathrm{CU}$.

Under our experimental conditions we obtained a high correlation between Utah and Dynamic models, which was also observed by other authors (Erez et al., 1990; Linsley-Noakes \& Allan, 1994; Erez \& Fishman, 1998; Ruiz et al., 2007), and a low correlation between Weinberger and both Utah and Dynamic models.

The use of molecular markers for the analysis of large collections of individuals for breeding purposes has increased during the last years, due to their improved robustness and simplicity when compared with traditional phenotyping methods. These molecular techniques have been made possible by the progressive identification of genes related to different physiological processes, favoured by the broad application of genomic tools to crop species. A previous use of gene expression markers in the dormancy field was approached by Yooyongwech et al. (2009), who measured the mRNA levels of two aquaporins (Pp- $\gamma$ TIP1 and Pp- $\gamma$ PIP1) in high and low-chill varieties, and showed that their increased expression can be used to indicate the state of dormancy release in peach buds. In this work we propose the use of five peach genes as gene expression markers for the evaluation of the dormancy stage of any known or new cultivar in a particular time. We chose 400 chilling hours for this single point evaluation, due to its rough intermediate position among the chilling requirement interval of peach varieties, however it could be changed according to the dormancy attributes of the assayed genotypes. This unique sample collection would reduce the complexity of evaluation of dormancy release by the excised shoots method since simple phenotyping methods are required in breeding programs .

Our group previously identified the five genes shown in this study as changing expression during the progression of bud dormancy. DAM5 is one of the six DAM genes identified as candidates for the evg mutation in peach (Bielenberg et al., 2008). This gene was also found in several 
transcriptomic approaches studying peach bud dormancy (Leida et al., 2010; Jiménez et al., 2010a). Its expression is higher after bud set in late summer/autumn ( $\mathrm{Li}$ et al., 2009) and during the dormancy period. This pattern is coherent with the role of DAM5 in the maintenance of the endodormant state, as suggested by Li et al. (2009). The ESTs DB396, DB247 and SB280 and the unigene PpB63 were identified in a library enriched in bud dormancy related transcripts obtained by suppression subtractive hybridization, and their abundance correlated with the chilling requirements of 10 peach cultivars after a microarray hybridization experiment (Leida et al., 2010; 2012). PpB63 codes for a peroxidase-like protein similar to other peroxidases found in Vitis riparia and leafy spurge related to bud break (Jia et al., 2006; Mathiason et al., 2009). Peroxidases have been proposed to have a role in $\mathrm{H}_{2} \mathrm{O}_{2}$ detoxification during the metabolic activation initiated by bud break. The up-regulation of $\mathrm{PpB} 63$ at this point supports this protective function and its use as an expression marker of dormancy release in buds.

According to the results obtained in this work, the expression values of these five genes correlate with the chilling requirement measurements performed following the Utah and Dynamic models. Thus, these genes could be used as expression markers for single point evaluation of the dormancy stage of different peach genotypes, amenable for use in plant breeding programs aiming to obtain varieties with modified climatic requirements. We recommend this molecular approach for the characterization of the natural diversity of chilling requirements among peach varieties. The analysis of gene expression could offer new additional tools for classifying new cultivars according to their adaptability to a given area. A better knowledge of the biochemical pathways involved in dormancy processes is needed in order to increase the number of dormancy-related genes available for screening. Expression of additional marker genes would increase the accuracy of a chilling determination method based on gene expression.

\section{Acknowledgements}

The research was supported by a grant from the Ministerio de Ciencia e Innovación AGL201020595. C.L. was funded by a $\mathrm{PhD}$ fellowship from the IVIA. 


5. Chilling-dependent release of seed and bud dormancy in peach associates to common changes in gene expression

This work has been submitted to review:

Leida C., Conejero A., Arbona V., Gómez-Cadenas A., Llácer G., Badenes M.L., Ríos G. “Chilling Chilling-Dependent Release of Seed and Bud Dormancy in Peach Associates to Common Changes in Gene Expression". 



\begin{abstract}
Reproductive meristems and embryos display dormancy mechanisms in specialized structures named respectively buds and seeds that arrest the growth of perennial plants until environmental conditions are optimal for survival. Dormancy shows common physiological features in buds and seeds. A genotype-specific period of chilling is usually required to release dormancy by molecular mechanisms that are still poorly understood. In order to find common transcriptional pathways associated to dormancy release, we analyzed the chilling-dependent expression in embryos of certain genes that were previously found related to dormancy in flower buds of peach. We propose the presence of short and long-term dormancy events affecting respectively the germination rate and seedling development by independent mechanisms. Short periods of chilling seem to improve germination in an abscisic acid-dependent manner, whereas the positive effect of longer cold treatments on physiological dwarfing coincides with the accumulation of phenylpropanoids in the seed.
\end{abstract}

\title{
Introduction
}

Perennial plants protect important and delicate tissues as reproductive meristems and embryos in specialized structures respectively designated buds and seeds. Growth of bud and embryo meristems leading respectively to blooming and germination is strictly regulated by dormancy mechanisms, which impose a physiological constraint to this growth until environmental conditions are optimal for long-term survival. Dormancy is released by dry storage of seeds (after-ripening), moist chilling of seeds (stratification) or a prolonged period of chilling in buds. In stone-fruit species, a high correlation between the chilling requirements for seed and bud dormancy release has been observed (Kester 1969; Pasternak et al., 1980), which suggests the presence of common regulatory mechanisms. Insufficient cold stratification of seeds in peach (Prunus persica), almond (Prunus dulcis), and other rosaceous plants may cause, in addition to low germination rates, a shoot development abnormality called physiological dwarfing (Hartmann et al., 2011). Physiological dwarfs are characterized by a temperature-dependent rosette-type habit of growth, with short internodes, and deformed leaves (Pollock 1962).

Seed dormancy has been observed throughout higher plants with physiological and morphological particularities in different species (Finch-Savage et al., 2006). In most popular model organisms, physiological dormancy integrates contributions from the embryo and the seed coat, being the coat 
component at least partially due to the mechanical resistance to breakage of endosperm and testa layers. The ratio of the hormones abscisic acid (ABA) and gibberellins (GA) is considered a relevant factor regulating seed dormancy processes. Several genetic approaches utilizing mostly mutant and transgenic lines of Arabidopsis thaliana and Solanaceae species have established that ABA is involved in induction and maintenance of dormancy, whereas GAs release dormancy and promote germination (Kucera et al., 2005). Other hormones as ethylene, brassinosteroids, auxin and cytokinins have been also proposed to affect dormancy and germination. The molecular factors and pathways conditioning seed dormancy status have been enumerated in several recent reviews (Bentsink et al., 2007; Finkelstein et al., 2008; Holdsworth et al., 2008; North et al., 2010). Early studies showed that the orthologous B3 class transcription factors encoded by VIVIPAROUS 1 (VP1) in maize and ABA-INSENSITIVE 3 (ABI3) in A. thaliana are involved in seed development and dormancy (McCarty et al., 1991; Giraudat et al., 1992). The basic leucine zipper (bZIP) transcription factor encoded by ABA-INSENSITIVE 5 (ABI5) interacts with $\mathrm{ABI} 3$ and mediates its effect on the expression of $\mathrm{ABA}$ responding genes thought the ABA-response element $\mathrm{ABRE}$ (Nakamura et al., 2001; Carles et al., 2002).

Bud dormancy in perennial plants resembles seed dormancy at the hormonal level (Powell 1987). The involvement of ABA in bud dormancy events is suggested by multiple physiological and transcriptomic studies (Arora et al., 2003; Horvath et al., 2003; Rohde et al., 2002; 2007), though few genetic approaches support this statement (Ruttink et al., 2007; Arend et al., 2009). The DORMANCY ASSOCIATED MADS-box (DAM) group of transcription factors related to SHORT VEGETATIVE PHASE (SVP) of A. thaliana, have been proposed to regulate bud dormancy processes in peach (Bielenberg et al., 2008), leafy spurge (Horvath et al., 2010) and Japanese apricot (Sasaki et al., 2011). DAM gene expression correlates with the dormancy state of buds, with higher transcript accumulation during the cold season followed by chilling-dependent downregulation prior to dormancy release (Horvath et al., 2010; Jiménez et al., 2010b; Yamane et al., 2011). Different transcriptomic approaches have been conducted in order to identify DAM-like and other genes related to dormancy at the expression level (Ruttink et al., 2007; Jia et al., 2006; Mazzitelli et al., 2007; Rohde et al., 2007; Horvath et al., 2008; Yamane et al., 2008; Mathiason et al., 2009; Jiménez et al., 2010a; Leida et al., 2010).

In order to find common molecular features between seed and bud dormancy processes, we investigated the expression of $D A M$ and other bud dormancy-dependent genes during the stratification of seeds in peach. The elucidation of general regulation pathways in both seed and bud 
structures may contribute to improve our basic knowledge on dormancy mechanisms, and be employed in plant breeding projects that profit from an early prediction of chilling requirements for blooming of new genotypes.

\section{Materials and Methods}

\section{Plant material and in vitro culture}

The Prunus persica (L. [Batsch]) cv 'Big Top' was grown in an orchard located at the Instituto Valenciano de Investigaciones Agrarias (IVIA) in Moncada (Spain) under standard agricultural practices. Mature fruits were collected and immediately broken to eliminate the endocarp with special scissors. Seeds were disinfected and flamed with alcohol, and then the coats were removed under sterile conditions. Embryos were cultured in a sterile Woody Plant Medium (Lloyd et al., 1981), solidified with 0,8\% Bacteriological Agar and distributed in $20 \mathrm{ml}$ aliquots into $25 \mathrm{x} 150$ $\mathrm{mm}$ culture tubes. Chilling treatment or stratification was performed by storing the tubes at $4^{\circ} \mathrm{C}$ in continuous darkness for $0,1,3,7$ or 9 weeks. After the stratification period, 10 embryos were frozen with liquid nitrogen and stored at $-80^{\circ} \mathrm{C}$ for RNA extraction, and 48 embryos were placed in a culture chamber at $24^{\circ} \mathrm{C}$. The embryos were maintained in darkness during the first week and then in 16 hours light-photoperiod conditions for the rest of the development. The germination and shoot emergence rates, height of seedlings, and dwarfing phenotype were noted once per week.

\section{Quantitative real-time RT-PCR}

Total RNA was isolated from $100 \mathrm{mg}$ of seeds deprived of their coats using the RNeasy Plant Mini Kit (Qiagen, Valencia, CA, USA), but adding 1\% (w:v) polyvinylpyrrolidone (PVP-40) to the extraction buffer before use. From 8 to 10 individuals were pooled for each sample. One microgram of total RNA was reverse transcribed with SuperScript III First-Strand Synthesis System for RTPCR (Invitrogen, Carlsbad, CA, USA) in a total volume of $20 \mu \mathrm{l}$. Two microliter of a 40X diluted first-strand cDNA were used for PCR reactions in a final volume of $20 \mu \mathrm{l}$. Quantitative real-time PCR was performed on a StepOnePlus Real-Time PCR System (Life Technologies, Carlsbad, CA, USA), using Perfecta SYBR Green SuperMix ROX (Quanta Biosciences, Gaithersburg, MD, USA). Primer pairs are listed in Table 1. Cycling protocol consisted of $10 \mathrm{~min}$ at $95^{\circ} \mathrm{C}$, followed by 40 cycles of $15 \mathrm{~s}$ at $95^{\circ} \mathrm{C}$ for denaturation, and $1 \mathrm{~min}$ at $60^{\circ} \mathrm{C}$ for annealing and extension. Specificity of the PCR reaction was assessed by the presence of a single peak in the dissociation curve after the 
amplification and through size estimation of the amplified product by agarose electrophoresis. We used as reference a peach Actin transcript amplified with specific primers. Relative expression was measured by the relative standard curve procedure. Results were the average of two independent biological replicates repeated twice.

Table 5.1. Primers employed in the quantitative real-time RT-PCR.

\begin{tabular}{|c|c|c|}
\hline Transcript (protein) & Forward primer & Reverse primer \\
\hline$D A M I$ & GGGGACGATGAAAATGACGAGGGAG & CAATCACCCGGCCAAGGCTTGCATC \\
\hline DAM4 & GAAGAGCTGGATCTGGATGAGTTGC & TCTGATTGTTGGCTTCTACCAGCTCAGT \\
\hline DAM5 & CCACATCAAACTGAGTAAGGAACTC & CTGCCTTAGCTGGTTGTTAGCTTCAACT \\
\hline DAM6 & TACTGGACCTGCGTTTGTGGAGCC & TGTTGCAGCTGGTGGAGGTGGCAATT \\
\hline $\begin{array}{l}\text { ppa012373m } \\
\text { (SAP-like) }\end{array}$ & ACACAGGCTTCCTCTACTCCATCTTT & GAACCCTCATTCCGAGACATTTATCAG \\
\hline $\begin{array}{l}\text { ppa012188m } \\
\text { (AWPM19-like) }\end{array}$ & CCCAGCCAATATGGCGAATATCAGAA & CATAGTGAGCAGCAGTAAGTTTGTGCT \\
\hline $\begin{array}{l}\text { ppa007606m } \\
\text { (DREB2-like) }\end{array}$ & TGAAGAGGGATGATGTTACTGGCGA & CACAAAATGACCAGACATGACAAGG \\
\hline $\begin{array}{l}\text { ppa008651m } \\
\text { (LEA protein) }\end{array}$ & TCATCTTCCGCTGCCTTTGTAGCCT & GACACTGCCAAGAACACCAAGGACA \\
\hline $\begin{array}{l}\text { ppa006974m } \\
\text { (AFP-like) }\end{array}$ & TTCCGTTGGTGGTGGAGTGGATGCA & TTACTAGCAGGGCTTCTTGCTTCAC \\
\hline ppa008548m & GAGCATGAAAGTGCTCATGGTCGATA & GCGTAACTAGAGAGTAAGATGACCTTG \\
\hline $\begin{array}{l}\text { ppa001608m } \\
\text { (ABI3-like) }\end{array}$ & ATGAGGTTAGGGTCTTCAGCTACGA & TAGTGCAATTCAGATCGGCTGCGTT \\
\hline $\begin{array}{l}\text { ppa012320m } \\
\text { (FT-like) }\end{array}$ & TCGGCAATTGGGTAGGCAAACA & TTAТСТТСТССТСССТССAGAG \\
\hline Actin & CAGATCATGTTTGAGACCTTCAATGT & CATCACCAGAGTCCAGCACAAT \\
\hline
\end{tabular}

\section{Plant hormone and metabolite analyses}

Plant hormones and phenolics were analyzed by LC/ESI-MS-MS essentially as described (Durgbanshi et al., 2005). Briefly, fresh frozen plant material was extracted in ultrapure water using a tissue homogenizer (Ultra-Turrax, Ika-Werke, Staufen, Germany) after addition of $50 \mu 1$ of a mixture of internal standards (see (Durgbanshi et al., 2005) for further details). After extraction and centrifugation, $\mathrm{pH}$ of the supernatant was adjusted to 3.0 and partitioned twice against di-ethyl-ether (Panreac, Barcelona, Spain). The organic layers were combined and evaporated in a centrifuge vacuum evaporator (Jouan, Saint-Herblain, France). The dry residue was thereafter resuspended in a water:methanol (9:1) solution, filtered and injected in a HPLC system (Alliance 2695, Waters Corp., Milford, MA, USA). Analytes were then separated in reversed-phase Kromasil 100 C18 
column (100 x $2.1 \mathrm{~mm}, 5 \mu \mathrm{m}$ particle size, Scharlab, Barcelona, Spain) using methanol and 0.01\% acetic acid in water as solvents at a flow rate of $300 \mu \mathrm{min}^{-1}$. The mass spectrometer, a triple quadrupole (Quattro LC, Micromass Ltd., Manchester, UK) was operated in negative ionization electrospray mode using $\mathrm{N}_{2}$ as nebulization and desolvation gas and set at 100 and $800 \mathrm{l} \mathrm{h}^{-1}$, respectively. During measurements, capillary voltage was set at $3.5 \mathrm{kV}$ whereas cone voltage was adjusted for every analyte. The precursor and product ions as well as cone and collision voltages were selected after direct injection of pure commercial standards into the mass spectrometer.

\section{Promoter analysis}

The promoter sequence of transcript models was obtained from peach genome database at phytozome (http://www.phytozome.net/cgi-bin/gbrowse/peach/). We selected 1-kb upstream sequence from the transcriptional start site when known, and from the translation start ATG in ppa006974m and ppa008548m genes. The ABRE element was located in these sequences applying a matrix-based procedure (Gómez-Porras et al., 2007). The core sequence of the CRT/DRE element (G/A)(C/T)CGAC was screened manually (Xue 2002). Finally, the RY-repeat element involved in seed-specific expression was searched using the Plant Cis-acting Regulatory DNA Elements Database (PLACE) (Higo et al., 1999).

\section{Results}

\section{Effect of stratification on seed germination and seedling development in peach}

An in vitro culture experiment was performed in order to characterize the response of peach embryos to different periods of cold stratification. The early variables germination rate, defined as the rate of embryos showing an apparent radicle, and shoot emergence were measured after $0,1,3$, 7 and 9 weeks of chilling treatment. After few days, the germination rate was nearly identical and total in embryos with periods of cold stratification of one week and longer, whereas about $80 \%$ of non-stratified embryos also showed root elongation (Figure 5.1A). The stratification also improved shoot growth but to a lesser extent. Embryos with three weeks and longer periods of chilling showed complete shoot emergence, whereas one-week and non-stratified samples had lower rates of emergence (Figure 5.1B).

In addition to these early observations on germination and shoot emergence, germinated embryos showed long-term effects of chilling on seedling development. At the end of the in vitro 
experiment, seedlings with $0-1$ weeks of stratification were small and not viable in most cases, whereas those with 3-9 weeks of chilling had higher size with variable rates of physiological abnormalities, as dwarfing (Figure 5.2A). The height of seedlings grown in vitro was radically improved by the cold treatment, with optimal values in plants stratified for 7 and 9 weeks (Figure 5.2B). The rate of dwarfed individuals was also lower after 7 and 9 weeks of stratification (Figure 5.2C). A qualitative classification of physiological dwarfs attending to the height of the plant, the presence of rosettes and the size and form of leaves was performed, assigning dwarfing values from 1 (those dwarfs more similar to normal plants) to 4 (those with deeper symptoms) (Figure 5.2D).

A
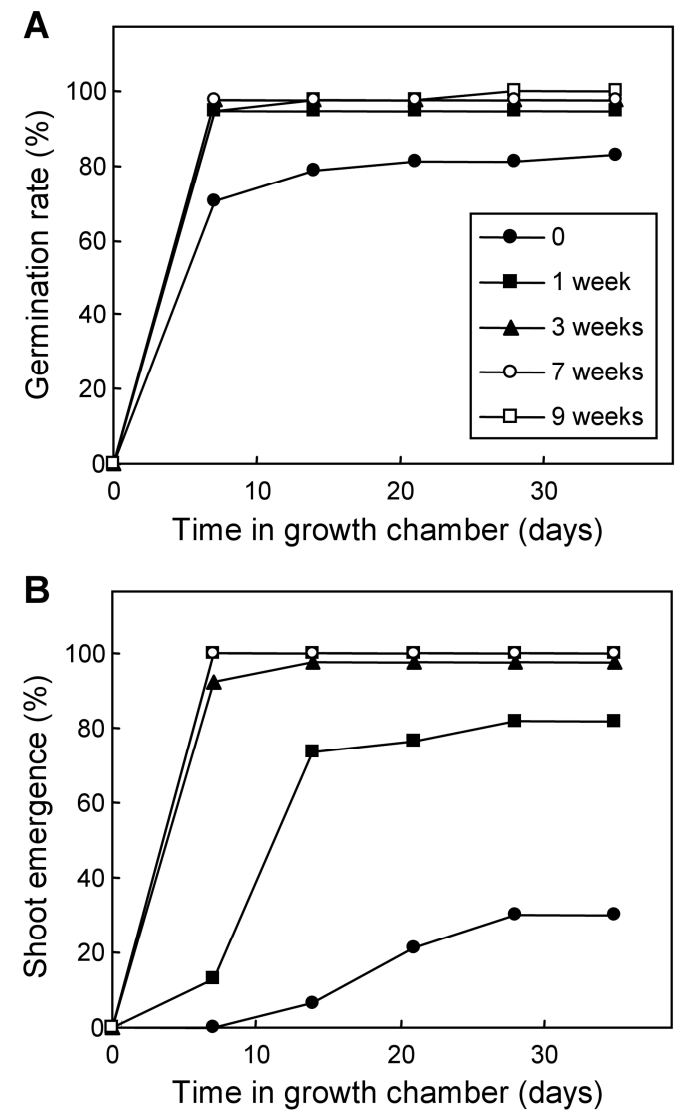

Figure 5.1. Effect of chilling on seed embryo germination and shoot emergence. The germination rate (A) and percentage of shoot emergence (B) were measured at different times after discrete periods of stratification: one week (black squares), three weeks (black triangles), seven weeks (white circles), nine weeks (white squares) and no stratification (black circles).

According to this classification, we found that chilling reduced the qualitative dwarfing level in a similar way to the dwarfing rate (Figure 5.2E). Plants stratified for 7 and 9 weeks grew actively during a time interval of three weeks, while those stratified for 3 weeks hardly increased their average height during the same period (Figure 5.2F). Interestingly, plants stratified for 7 and 9 weeks also reduced their rate of dwarfing in this time interval, due to an overall recovery of growth by the appearance of lateral shoots with normal development (Figure 5.2G). 
A

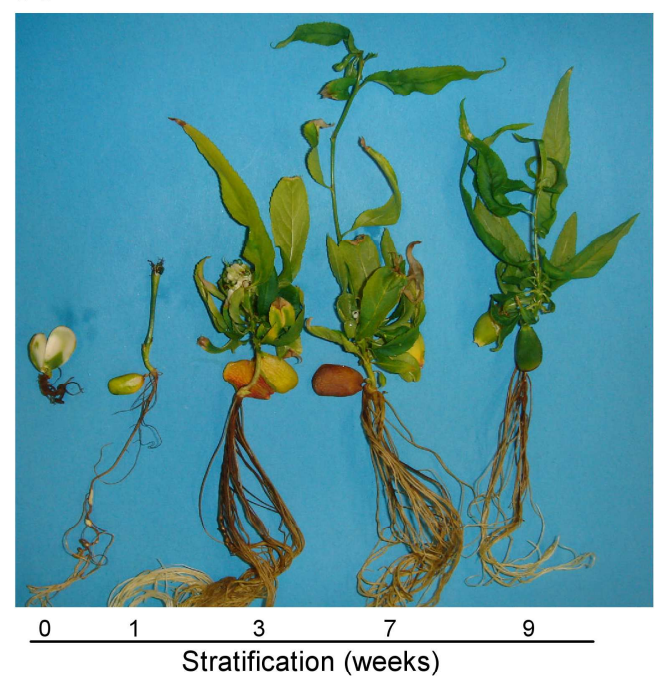

D

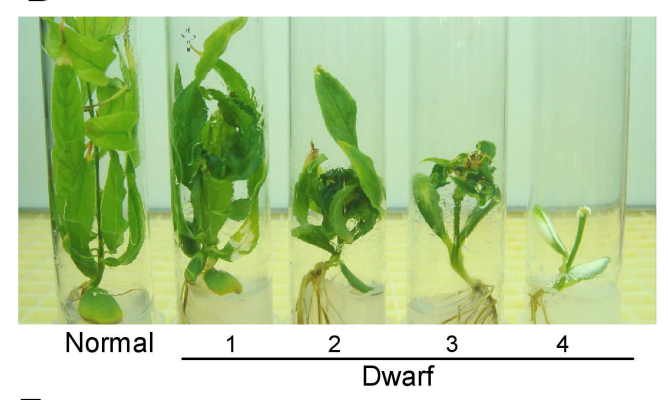

$\mathbf{F}$

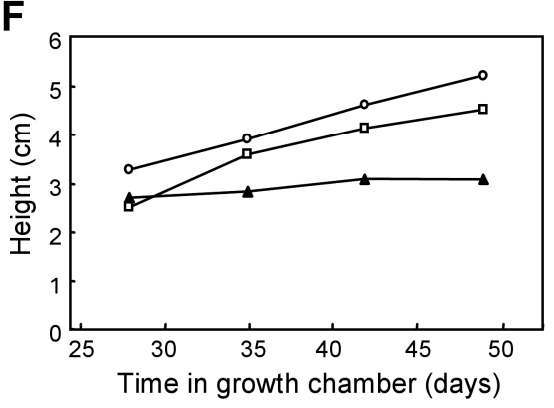

B

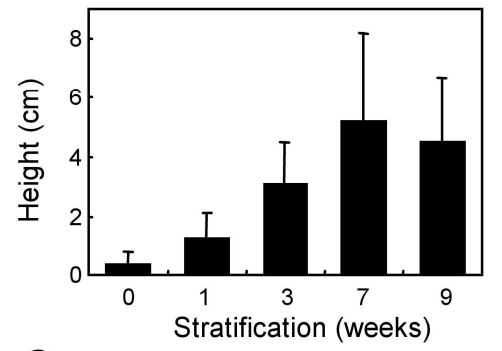

C

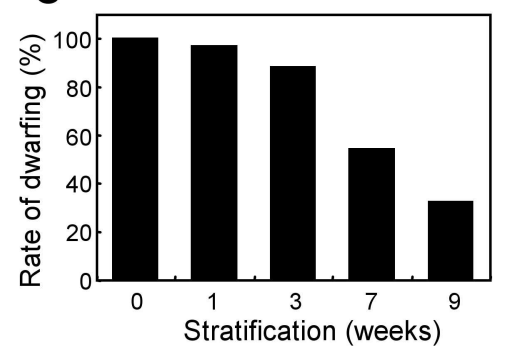

E

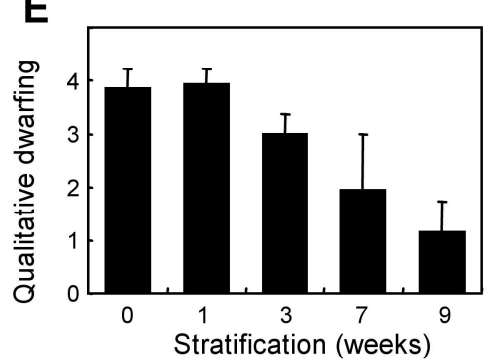

$\mathbf{G}_{1}$

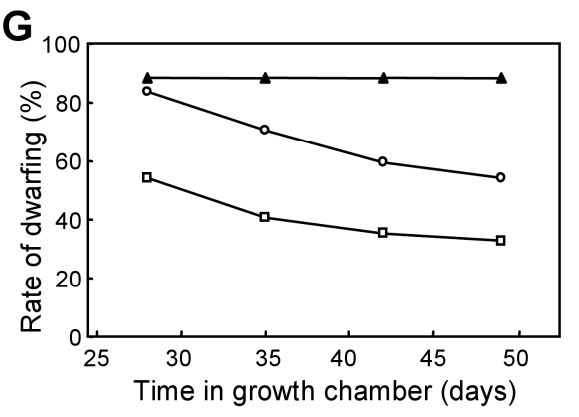

Figure 5.2. Effect of chilling on the physiological dwarfing of seedlings.

(A)

Representative plants subject to different stratification periods were photographed at the end of the in vitro experiment. (B) Average height of seedlings after seven weeks in growth chamber. (C) Percentage of dwarfed plants after seven weeks in growth chamber. (D) Representative seedlings showing different qualitative levels of dwarfism: level 1 individuals were slightly shorter than normal ones and had both normal and curved leaves; level 2 seedlings had shorter internodes and mostly abnormal leaves; level 3 dwarfism led to small deformed leaves grouped in a rosette-like structure; and finally level 4 dwarfs had a drastic reduction of growth and barely recognizable leaves. (E) Average qualitative dwarfing of seedlings grown for seven weeks. The height $(\mathrm{F})$ and rate of dwarfing $(G)$ of seedlings obtained from embryos stratified for three (black triangles), seven (white circles) and nine weeks (white squares), were measured at different times. In (B) and (E), error bars represent standard deviation, $n>35$.

\section{Regulation of gene expression in stratified seeds}

Previous transcriptomic approaches performed in our group, based on transcript enrichment by suppression subtractive hybridization ( $\mathrm{SSH}$ ) and cDNA microarray hybridization, led to a set of genes differentially expressed during bud dormancy release in peach (Leida et al., 2010; 2012). We selected several of these genes, previously validated by quantitative real-time RT-PCR on buds, for its expression analysis in peach embryos subject to the stratification treatments described above. The genes DAM1, DAM4, DAM5 and DAM6 are components of the DAM multigene family coding for MADS-box transcription factors involved in bud dormancy regulation in peach and other 
species. DAMI and DAM6 reduced gradually their expression during the chilling treatment to reach their lowest values in 7 and 9 weeks samples (Figure 5.3). DAM5 gene showed a sharp and permanent down-regulation after one week under stratification, in contrast with the increase of DAM4 expression in the same period. However, DAM4 transcript accumulation experienced a slight reduction in consecutive time samples.

We assayed other genes down-regulated during bud dormancy release, related to elements of the ABA and drought stress response in A. thaliana (Leida et al., 2012). The genes coding for STRESS ASSOCIATED PROTEIN (SAP)-like (peach transcript model ppa012373m), AWPM19-like (ppa012188m), DEHYDRATION-RESPONSIVE ELEMENT BINDING PROTEIN2 (DREB2)like (ppa007606m), and LATE EMBRYOGENESIS ABUNDANT (LEA) protein (ppa008651m) reduced drastically their expression in stratified embryos (Figure 3), as previously observed in peach buds subject to environmental chilling. The ABA-INSENSITIVE FIVE BINDING PROTEIN $(A F P)$-like gene showed an early down-regulation in the first chilling week, followed by a slow recovery to reach initial expression values. Most of transcripts accumulating in buds after dormancy release had a negligible expression in embryos, but ppa008548m coding for a putative cinnamoylCoA reductase showed detectable expression after 7 and 9 weeks of stratification.

We analyzed by quantitative real-time RT-PCR two additional transcripts that were not previously identified in our transcriptomic experiments, but were considered putative candidates to affect dormancy responses in seeds and buds. The ABA-INSENSITIVE 3 (ABI3)-like transcript (ppa001608m) strongly declined during the first three weeks of chilling, whereas FLOWERING LOCUS T (FT)-like (ppa012320m) had higher expression values in last stratification stages (Figure $5.3)$. 

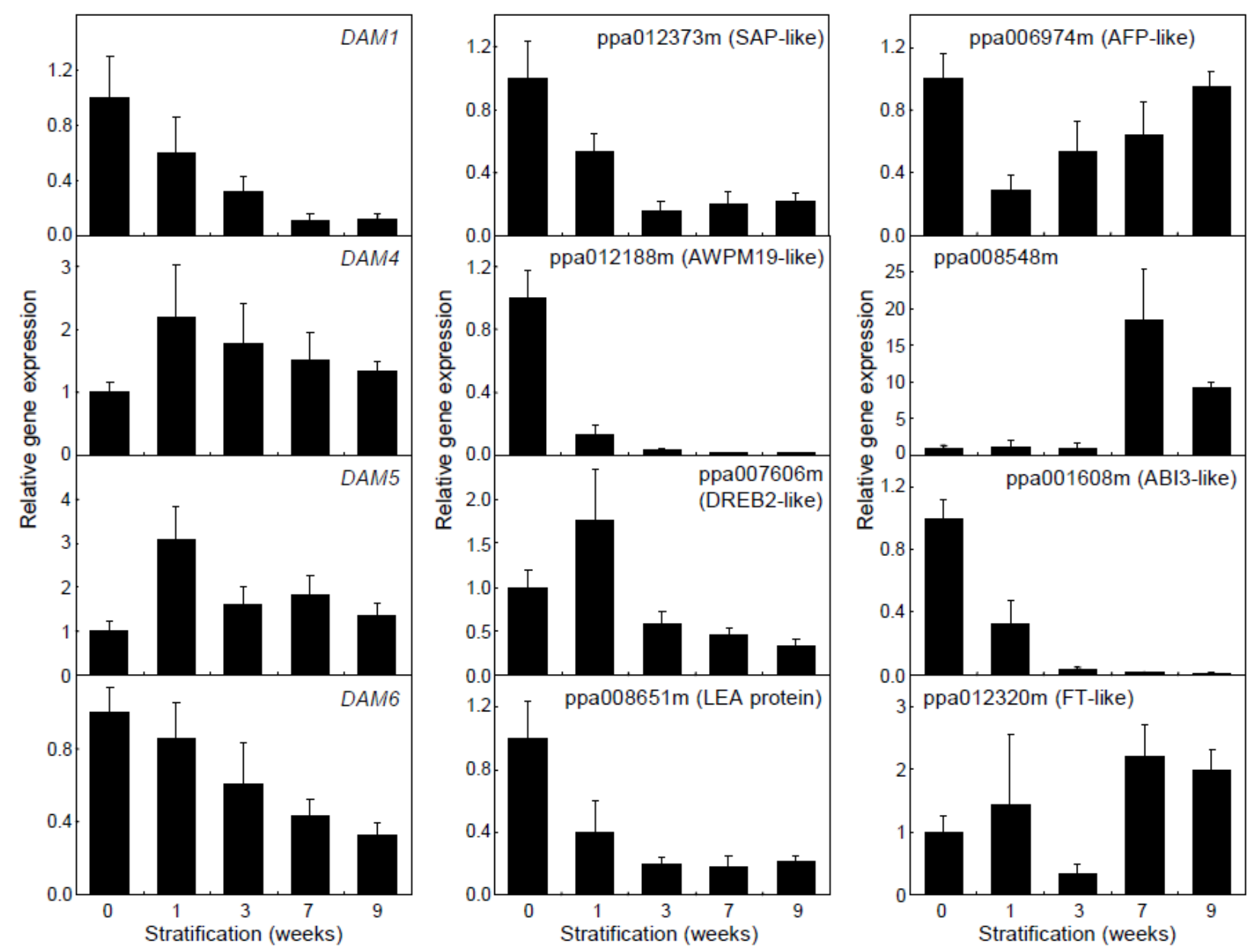

Figure 5.3. Expression of selected genes in stratified embryos. Relative expression of bud-dormancy related genes was determined by quantitative real-time RT-PCR with specific primers (Table 5.1). The name of the gene or transcript model is shown in the upper side of the graph. Expression levels are relative to Actin. An expression value of one is assigned to the non-stratified sample. Data are means from two biological replicates, with error bars representing standard deviation.

\section{ABA content rapidly decreases during stratification}

The ABA content in stratified embryos decreased from about $140 \mathrm{ng}$ per gram (fresh weight) to less than $10 \mathrm{ng}$ after one week of chilling. The hormone content did not change relevantly after longer chilling treatments (Figure 5.4).

In order to identify cis-regulatory elements responding to ABA and drought stress in the genes analyzed by quantitative real-time RT-PCR, we examined $1 \mathrm{~kb}$ sequence of their promoters beginning from the transcription start when known, otherwise the translation start ATG was used. We performed a search of ABA-responsive elements (ABRE), C-repeat/dehydration-responsive elements (CRT/DRE), and RY repeats as described in Materials and Methods. Genes repressed by chilling treatment had at least one of these three elements in their promoters with the exception of 
$D A M 1$ gene, and four of them had the three elements (Figure 5.5). We did not find any of these regulatory sequences in the promoter of the ppa008548m gene induced by cold stratification.
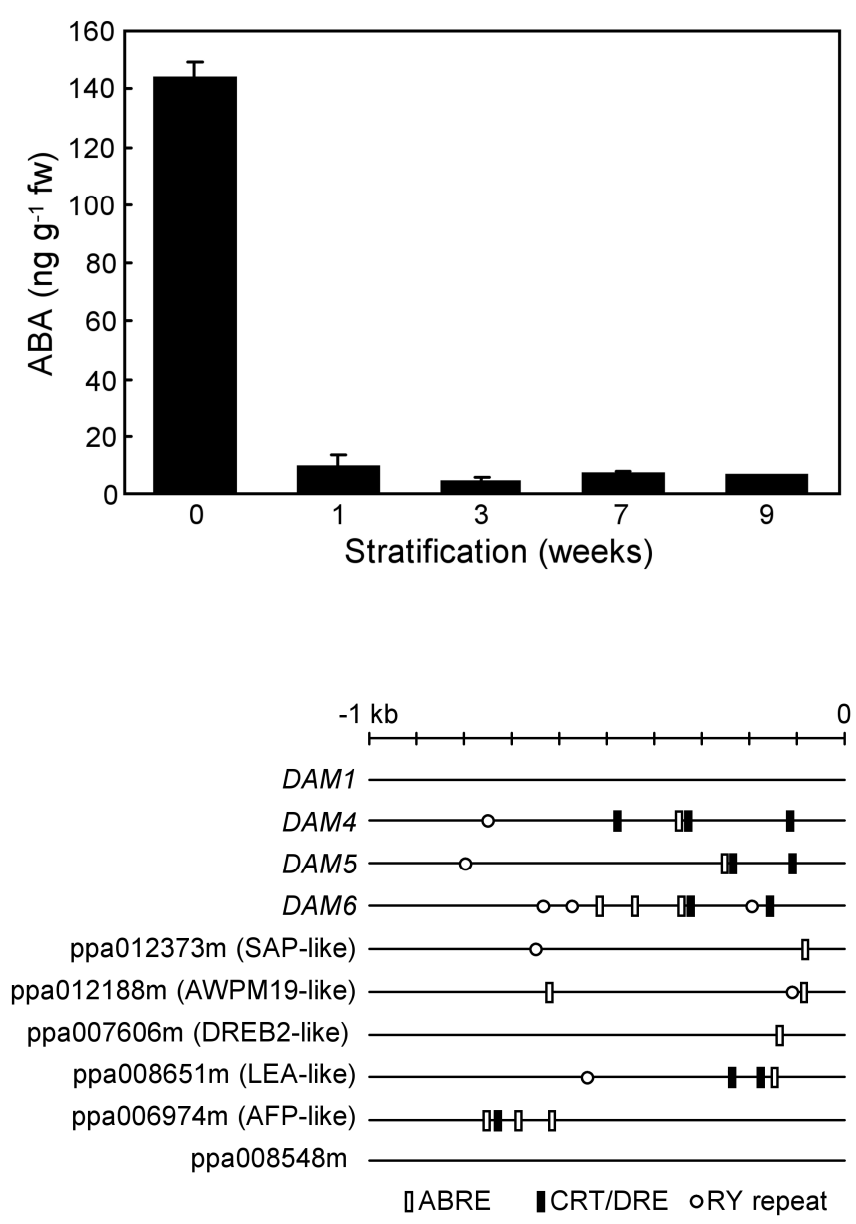

Figure 5.4. Abscisic acid content in stratified embryos. Abscisic acid content was determined as detailed in Materials and Methods. Data are means from three biological replicates, with error bars representing standard deviation.
Figure 5.5. Predicted cis-elements in the promoter of chilling-regulated genes. The $\mathrm{ABA}$-response element (ABRE, white rectangles), C-repeat/dehydrationresponsive element (CRT/DRE, black rectangles), and seed-specific RY repeats (white circles) were localized in the 1-kb upstream sequence from the transcriptional start site when known, and from the translation start (in ppa006974m and ppa008548m), of chilling affected genes, as described in Materials and Methods.

\section{Phenylpropanoid metabolites accumulate during prolonged cold treatment}

A systematic analysis of metabolites was performed in stratified embryos. We found several intermediate metabolites of the phenylpropanoid biosynthesis pathway accumulating in embryos stratified for 7 and 9 weeks. Among them, the ferulic acid approximately doubled its initial content during long chilling treatments (Figure 5.6). Over-accumulation of other compounds from this pathway was even more pronounced. Caffeic, coumaric and cinnamic acids increased respectively 40-fold, 100-fold and 4-fold after a stratification period of 7 weeks, followed by a slight decrease two weeks later. Interestingly, the hormone salicylic acid increased its content during the chilling treatment in a similar way to phenylpropanoid metabolites (Figure 5.6). However, the addition of salicylic acid to the culture medium at different concentrations did not ameliorate the germination or physiological dwarfing defects observed in peach seeds (data not shown). 


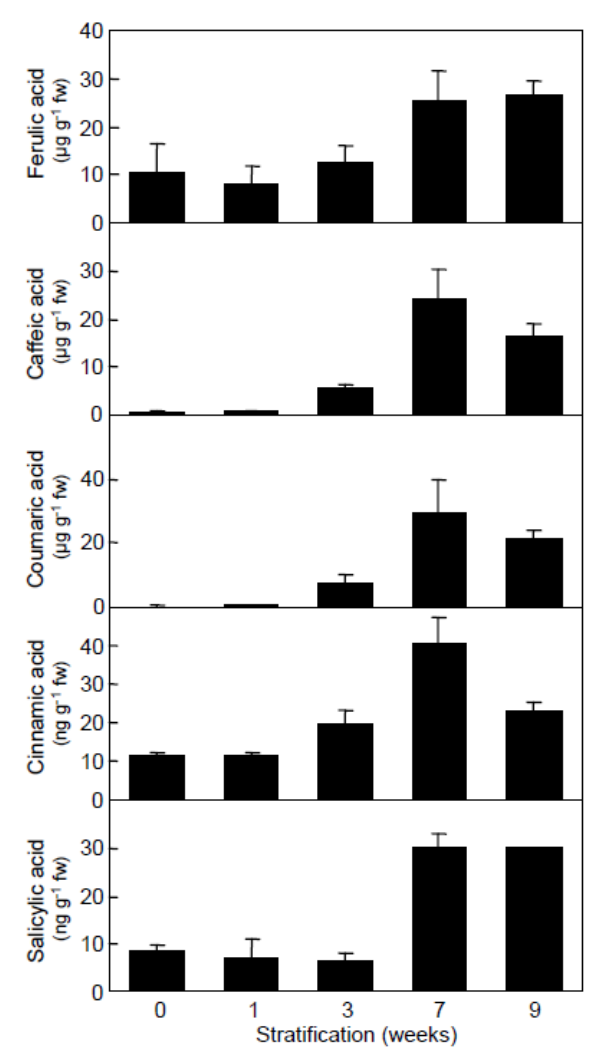

Figure 5.6. Accumulation of phenylpropanoids in stratified embryos. Ferulic, caffeic, coumaric and cinnamic acids, and the phytohormone salicylic acid were determined in embryos after different chilling treatments. Data are means from three biological replicates, with error bars representing standard deviation.

\section{Discussion}

Stratification has short and long-term effects on peach germination and development

Short chilling treatments of one and three weeks were sufficient for optimal germination and shoot emergence, respectively. These chilling requirements for radicle and shoot growth were lower than those reported by other physiological studies (Davies 1983; Frisby \& Seeley, 1993), which may be due to genotype-based differences or most likely to previous removal of the seed coat in our samples. Coat excision helped to discard the mechanical and physiological contribution of the coat to seed dormancy, which in consequence was exclusively dependent on the embryo component. This experimental procedure was essential to distinguish two separate effects of cold stratification on seed germination and seedling development. Thus, in addition to early benefits of chilling on germination and shoot emergence, longer chilling treatments of seven and nine weeks contributed to prevent the physiological dwarfing of seedlings. This double effect of stratification on germination and subsequent development of seedlings has been noted previously in stone-fruit species (Hartmann et al., 2011; Martínez-Gómez \& Dicenta, 2001), but no molecular mechanisms have been proposed to explain it. The improved germination ratio observed after one week of chilling was associated to a drastic reduction in ABA content, in close agreement with the known role of 
this hormone in the induction and maintenance of dormancy in seeds. However, the alleviation of dwarfing abnormalities at long chilling treatments was not related to changes in $\mathrm{ABA}$, which precludes a function of ABA in post-germinative dormancy events.

Other compounds as salicylic acid and the phenylpropanoids ferulic, caffeic, coumaric and cinnamic acids accumulated in embryos stratified for seven to nine weeks leading to seedlings with low rate of dwarfing. Overproduction of these compounds could benefit the normal development of seedlings or simply be a biochemical feature of dormancy-released embryos prepared to develop normally, however we have not obtained experimental evidences supporting any of these hypotheses. The phenylpropanoids pathway results in the synthesis of the monolignols p-coumaryl, coniferyl and sinapyl alcohols, which are the main precursors of lignin polymers, through the sequential activity of cinnamoyl CoA reductase (CCR) and cinnamyl alcohol dehydrogenase (CAD) enzymes (Boerjan et al., 2003). Lignin deposition contributes to the secondary thickening of the cell wall, and takes part in xylem cell differentiation. The synthesis of this complex polymer becomes detectable in early stages of seedling development in A. thaliana, associated to the developing vasculature (Dharmawardhana et al., 1992). Interestingly, a triple A. thaliana null mutant in one CCR and two CAD genes, leading to a strong reduction in lignin deposition, displayed a severe dwarf phenotype and abnormal leaf morphology (Thévenin et al., 2011), resembling the symptoms of physiological dwarfing described in this work. These observations and the high-chilling dependent induction of ppa008548m in stratified embryos (Figure 5.3), coding for a predicted protein similar to $\mathrm{CCR}$, suggest the participation of phenylpropanoids and lignin biosynthesis pathways in the alleviation of anomalies associated to physiological dwarfing.

\section{Bud and seed dormancy regulate a common set of genes}

The quantitative real-time RT-PCR analysis of genes previously related to bud dormancy revealed a parallel pattern of gene expression in buds and embryos. A relevant number of genes downregulated during bud dormancy release after the fulfilment of cultivar-specific chilling requirements were also repressed by cold stratification in embryos. This suggests the presence of common regulatory pathways in dormancy release mechanisms of buds and seeds. The in silico search of known homologous genes in other species and cis-elements in their promoters pointed to a common effect of ABA and drought signalling on such genes. However ABA could only account for transcript accumulation changes observed during the first week of chilling, due to the stabilization 
of $\mathrm{ABA}$ content after this time. Consequently, later down-regulation of the expression of these genes should be assigned to additional regulatory pathways.

$D A M$ genes are particularly interesting among this set of genes. DAM have been related to bud dormancy maintenance by expression and functional studies in multiple species, and are considered the major known regulators of this process. The fact that DAM1, DAM5 and DAM6 are also significantly repressed during chilling treatment of the embryo suggests their participation in mechanisms of transcriptional regulation associated to release of seed dormancy by stratification. Additional evidences of $D A M$ function in seed dormancy would be obtained by further analyses of the evergrowing mutant in peach carrying a deletion in DAM genes (Bielenberg et al., 2008) and transgenic plants expressing constitutively these genes (Sasaki et al., 2011).

Previous molecular studies relating seed germination and flowering in A. thaliana have been recently published. The FLOWERING LOCUS C (FLC) gene coding for a MADS box transcription factor involved in flowering time regulation through the vernalization pathway, also affected the temperature-dependent germination of dormant seeds (Chiang et al., 2009). The effect of FLC on seed germination was most likely mediated by FLOWERING LOCUS T(FT), which also takes part in the flowering pathway. Interestingly, a peach gene similar to $F T$ increased its expression after stratification during 7-9 weeks (Figure 5.3), which points to the presence of a related signalling pathway in peach. The RNA Polymerase II Associated Factor 1 Complex (PAF1C) of A. thaliana has been also proposed to have a dual role in flowering and seed dormancy (Liu et al., 2011). Moreover, a poplar orthologue of ABSCISIC ACID INSENSITIVE 3 (ABI3) gene, involved in the ABA-dependent expression of many seed-specific genes in A. thaliana, is expressed in buds during bud set and causes some alterations in bud development when overexpressed and silenced (Rohde et al., 2002).

The transcriptional similarities between bud and seed dormancy highlighted in this work may also be relevant for plant breeding purposes. The selection of early and late flowering genotypes from a segregating population usually requires the arduous evaluation of large collections of individuals, which could be improved by a previous selection of the desirable trait at the seed level. Previous studies found a positive correlation between the chilling requirements for seed germination and blooming in almond and apple (Kester et al., 1977; Mehlenbacher \& Voordeckers, 1991). This work contributes to characterize the molecular bases underlying these and other physiological observations with high interest to plant breeders. 


\section{Acknowledgments}

We thank José Martínez, Enzo Stasi and José Palanca for technical assistance in the plant material maintenance. 


6. GENERAL DISCUSSION 



\section{DAM genes are relevant regulators of dormancy processes}

The peach transcriptional models ppa011123m, ppa010822m and ppa010714m, corresponding to MADS-box genes DAM4, DAM5 and DAM6, were identified in an initial transcriptomic study based on the SSH procedure (Leida et al., 2010) and in the subsequent microarray hybridization experiment comparing 10 cultivars with different chilling requirements (Leida et al., 2012). Realtime RT-PCR analysis confirmed that DAM gene expression changes during flower bud development according to the dormancy stage, and correlates with dormancy-related parameters of different cultivars. Other authors, working independently, observed similar season and dormancydependent modifications of DAM-like gene expression in peach buds (Jiménez et al., 2010b; Yamane et al., 2011), and in other species as raspberry (Mazzitelli et al., 2007), Japanese apricot (Yamane et al., 2008), poplar (Druart et al., 2007), and leafy spurge (Horvath et al., 2008).

The central role of DAM genes in dormancy regulation of vegetative and reproductive buds has been confirmed by additional functional approaches. Four of the six tandemly arrayed DAM genes were found deleted in the evg mutant of peach showing non-dormant phenotype, suggesting that they are required for dormancy setting up (Bielenberg et al., 2008). Moreover, a genetic mapping approach using a family of peach, segregating for chilling requirements, heat requirement and flowering time identified a major QTL for these traits that fairly overlapped with DAM locus on linkage group I (Fan et al., 2010). Transgenic poplar plants expressing constitutively a DAM-like gene from Japanese apricot showed growth cessation and terminal bud set under favourable conditions (Sasaki et al., 2011), whereas overexpression of peach DAM6 in plum, resulted in accentuated branching and dwarfing of plants suggesting a growth inhibitory effect of these genes (Fan, 2010).

Interestingly, the deletion of four of the DAM genes in the evg mutant caused the transcriptional inhibition of the other two structurally intact genes of the family (Bielenberg et al., 2008). This observation and the apparently sequential activation of DAM1 and DAM6 genes (Leida et al., 2010) suggest a kind of reciprocal regulation between these genes, which could only be tested by biochemical ways.

In order to know the mechanism of dormancy regulation we study the molecular mechanisms of DAM6 down-regulation concomitant with dormancy release in flower buds. A ChIP analysis of DAM6 promoter and structural gene revealed chromatin modification events similar to those observed in vernalization of Arabidopsis and cereals. 
Certain biannual Arabidopsis lines require a prolonged period of cold accumulation during winter prior to flowering named vernalization. Vernalization represses the expression of the FLC gene, coding for a MADS-box transcription factor that inhibits flowering transition. The mechanism of $F L C$ repression involves numerous epigenetic events, including micro RNA synthesis and covalent modification of histones. The N-terminal tail of histone H3 located on FLC promoter is highly acetylated and trimethylated at the lysine $\mathrm{K} 4$ when the gene is transcriptionally active. Changes triggered by vernalization on $\mathrm{H} 3$ include demethylation of $\mathrm{K} 4$, deacetylation of $\mathrm{K} 9$ and $\mathrm{K} 14$, and methylation of K27 and K9. Trimethylation of H3K27, catalyzed by PcG complexes, plays a critical role in maintenance of FLC stable repression. Some similarities between vernalization gene repression in Arabidopsis and PcG-mediated gene repression in animals are evident despite certain differences (Sung \& Amasino, 2005).

In cereals, vernalization response involves epigenetic regulation of the MADS-box gene VRN1, targeted by histone modification complexes similar to those repressing FLC. H3K27 trimethylation at the VRN1 locus causes mitotically stable repression of VRN1 until plants experiment cold conditions. Vernalization activates protein complexes that reverse these modifications to activate VRN1 expression, by increasing the rate of trimethylated $\mathrm{H} 3 \mathrm{~K} 4$ and decreasing the rate of trimethylated $\mathrm{H} 3 \mathrm{~K} 27$, as described in barley HvVRN1 locus (Oliver et al., 2009).

We showed that the MADS-box gene DAM6 is transcriptionally active in dormant peach flower buds collected in October. At this point a short chromatin region around its ATG is trimethylated at $\mathrm{H} 3 \mathrm{~K} 4$ and acetylated at the N-terminal tail of H3. Concomitantly with DAM6 repression, H3K4 became demethylated and H3 deacetylated. Later H3K27 was trimethylated along a genomic region larger than $4 \mathrm{~kb}$, including promoter, coding sequence and intron. We postulated a possible sequence of DAM6 chromatin modification events during dormancy regulation: 1) Trimethylation of H3K4 and acetylation of $\mathrm{H} 3$ are modifications of the chromatin structure associated to active gene expression. 2) Buds undergoing dormancy lose the trimethylation mark at $\mathrm{H} 3 \mathrm{~K} 4$ and $\mathrm{H} 3$ acetylation, leading to gene repression. 3) Finally, trimethylation of H3K27 mediates the stable repression of the gene.

These observations suggest that DAM6 responds to chilling accumulation by epigenetic mechanisms similar to FLC and VRN1. The common enrichment of trimethylated $\mathrm{H} 3 \mathrm{~K} 27$ along the transcriptionally repressed chromatin of DAM6, FLC and VRN1 supports the presence of related PcG-like multiprotein complexes with methyl-transferase activity. Thus, PcG complexes are 
potentially involved in the stable repression of DAM6 after dormancy release until the next dormancy cycle.

Due to their relevance in dormancy regulation, $D A M$ genes could be utilized as expression markers to assess the dormancy stage of an individual plant and to evaluate the chilling requirements of new cultivars. In fact, we studied the expression pattern of DAM5, together with other transcripts (BD396, DB247, SB280 and PpB63), they correlated well with chilling requirements values of five varieties differing in chilling requirements ('Big Top', 'Catherina', 'Fergold', 'Maruja' and 'Springlady') measured following Utah and Dynamic models.

A further characterization of the function of these genes will be essential for understanding and future manipulation of dormancy in perennial trees. A deeper analysis of transgenic plants overexpressing these genes will contribute to understand their influence in plant development and dormancy regulation. Additional molecular approaches as the two-hybrid system and chromatin immunoprecipitation using specific antibodies may help to clarify the protein interactions required for proper function of these factors, and to identify target promoters. These and other biochemical and molecular approaches will improve our basic knowledge on the signal transduction pathways involved in dormancy regulation.

\section{Dormancy in bud and seed has common regulatory pathways}

Some of the genes identified in our transcriptomic experiments using flower buds, as DAM1, DAM5 and DAM6, were also regulated during the cold stratification of peach seeds, suggesting the presence of common regulatory pathways in the dormancy process of buds and seeds. These similarities between bud and seed dormancy have potential implications in the evaluation of bud chilling requirements of peach genotypes at seed level. The measurement of the relative expression of DAM and other genes in seeds could provide a method for evaluating chilling requirements of plant material at very early stages of development greatly reducing the time needed for evaluating plant material in breeding programs. A positive correlation between seed germination and blooming date has been found in apple and almond, supporting this link between dormancy in buds and seeds at the phenotypical level (Kester et al., 1977; Mehlenbacher et al., 1991).

\section{Many ABA dependent genes are down-regulated during dormancy release}

ABA has been proposed to promote and maintain bud dormancy (Arora et al., 2003; Horvath et al., 2003; Rohde \& Balherao, 2007) although few molecular data support this prediction. A significant number of genes identified in this work were homologous to ABA and drought related genes from 
other species. Ppa006974m codes for a protein similar to ABA-INSENSITIVE5 (ABI5) binding protein (AFP) involved in signal transduction in Arabidopsis. AFP binds and promotes the degradation of ABI5. ABI5 is a basic leucine zipper (bZIP) transcription factor that regulates ABAdependent genes by binding to the ABA-responsive element, ABRE (Lopez-Molina et al., 2003). Additionally, drought stress modulates gene expression through the dehydration-responsive element (DRE) and their DRE-binding proteins (DREB; Liu et al., 1998), similar to the transcript model ppa007606m encoding a DREB2C-like factor. The product of ppa008849m is similar to calcium binding annexins involved in ABA and osmotic stress signal transduction in Arabidopsis (Lee et al., 2004).

Our results contributed to the identification of peach genes regulated by ABA, drought and salt stress as ppa008979m (AtMYB44-like), ppa008651m (LEA), ppa012373m (A20/AN1 zinc-finger), ppa005514m (dehydrin) and ppa012188m (AWPM-19-like), involved in cold hardening and frost tolerance. Several orthologues of these genes conferred increased cold resistance in different transgenic plants (Jung et al., 2008; Mukhopadhyay et al., 2004; Lee et al., 2010; Artlip et al., 1997; Koike et al., 1997).

For instance, ppa012373m protein shows A20/AN1 zinc-finger domains that have been already described in other eukaryotes. In animals, ZNF216 protein regulates nuclear factor NFkB, involved in the immune and inflammation response reaction (Hishaya et al., 2006). The same protein, which plays a critical role in muscle atrophy, contains an A20 domain that binds ubiquitin and participates in the ubiquitin-proteasome pathway of protein degradation (Huang et al., 2004). In plants, proteins related to ppa012373m that are expressed under cold and salt stress conditions have been grouped into the stress associated protein (SAP) family. Experiments on Arabidopsis showed that modifications in the cytosolic redox state, as the one induced by stress conditions, cause a conformational change in SAP proteins. The fast up-regulation of SAP12 in Arabidopsis after $6 \mathrm{~h}$ of stress and its subsequent down-regulation after $48 \mathrm{~h}$, suggests a possible role in rapid transmission of redox information under stress conditions (Ströher et al., 2009). If these proteins are part of an ABA or stress-dependent pathway for regulation of dormancy events may only be assessed after deep biochemical and genetic studies. 


7. CONCLUSIONS 

1. In two different transcriptomic approaches, we obtained 137 cDNAs related to dormancy release in flower buds of peach. Some of them, as ppa011123m, ppa010822m and ppa010714m (DAM4, DAM5 and DAM6) were previously found associated to dormancy processes.

2. The isolation of certain transcripts involved in ABA, salt and drought stress regulation, such as ppa007606m (DREB2C-like), ppa006974m (AFP-like), and ppa008849m (annexin-like), supports the role of $\mathrm{ABA}$ and drought responses in bud dormancy events, and contributes to identify putative regulatory factors of both pathways in peach.

3. DAM6 gene expression is regulated at the chromatin level. Demethylation of $\mathrm{H} 3 \mathrm{~K} 4$ and deacetylation of $\mathrm{H} 3$ in the region around the ATG, and trimethylation of H3K27 in a large genomic stretch of at least $4 \mathrm{~kb}$, associate to DAM6 repression, concomitantly with dormancy release.

4. The expression profile of five cDNAs (DAM5, DB396, DB247, SB280 and PpB63) correlated well with the chilling requirements of five cultivars ('Big Top', 'Catherina', 'Fergold', 'Maruja' and 'Springlady') measured following the Utah and Dynamic models. These genes were proposed as expression markers for single point evaluation of the dormant stage of peach genotypes.

5. Cold stratification had a short-term effect on germination of peach seeds, coincident with a decrease in ABA content.

6. We observed that a long-term (7-9 weeks) seed stratification have a positive effect in decreasing the developmental abnormalities on seedlings named "physiological dwarfing". This amelioration was associated with the accumulation of several intermediate metabolites of the phenylpropanoid biosynthesis pathway (salicylic, ferulic, caffeic, coumaric and cinnamic acids), involved in xylem synthesis.

7. A set of genes regulated during dormancy release shared by buds and seeds indicated the presence of common regulatory pathways of dormancy release in both organs. 

8. REFERENCES 

Alboresi A., Gestin C., Leydecker M.T., Bedu M., Meyer C., Truong H.N. 2005. Nitrate, a signal relieving seed dormancy in Arabidopsis. Plant Cell Environ. 28: 500-512.

Alburquerque N., García-Montiel F., Carrillo A., Burgos L. 2008. Chilling and heat requirements of sweet cherry cultivars and the relationship between altitude and the probability of satisfying the chill requirements. Environ. Exp. Bot. 64: 162-170.

Allan P., Rufus G., Linsley-Noakes G.C., Matthee G.W. 1995. Winter chill models in a mild subtropical area and effects of constant $6^{\circ} \mathrm{C}$ chilling on peach bud break. Acta Hortic. 409: 9-17.

Allona I., Ramos A., Ibañez C., Contreras A., Casado R., Argoncillo C. 2008. Molecular control of winter dormancy establishment in trees. Span. J. Agric. Res. 6: 201-210.

Alonso-Blanco C., Aarts M.G.M., Bentsink L., Keurentjes J.J.B., Reymond M., Vreugdenhil D., Koornneef M. 2009. What has natural variation taught us about plant development, physiology and adaptation? Plant Cell. 21: 18771896.

Alsheikh, M.K., Svensson, J.T., Randall, S.K. 2005. Phosphorylation regulated ion-binding is a property shared by the acidic subclass dehydrins. Plant Cell Environ. 28: 1114-1122.

Altschul, S.F., Gish W., Miller W., Myers E.W., Lipman D.J. 1990. Basic local alignment search tool. J. Mol. Biol. 215:403-410.

Andersson A., Keskitalo, J., Sjodin, A., Bhalerao R., Sterky F., Wissel K., Tandre K., Aspeborg H., Moyle R., Ohmiya Y., Bhalerao R., Brunner A., Gustafsson P., Karlsson J., Lundeberg J., Nilsson O., Sandberg G., Strauss S., Sundberg B., Uhlen M., Jansson S. Nilsson P. 2004. A transcriptional timetable of autumn senescence. Genome Biol. 5: 24-37.

Arend M., Schnitzler J.P., Ehlting B., Hänsch R., Lange T., Rennenberg H., Himmelbach A., Grill E., Fromm J. 2009. Expression of the Arabidopsis mutant ABI1 gene alters abscisic acid sensitivity, stomatal development, and growth morphology in gray poplars. Plant Physiol. 151: 2110-2119.

Arora R., Wisniewski M.E. 1994. Cold acclimation in genetically related (sibling) deciduous and evergreen peach, Prunus persica. II. A 60-kilodalton bark protein in cold acclimated tissues of peach is heat-stable and related to the dehydrin family of proteins. Plant Physiol. 105:95-101.

Arora R., Wisniewski M.E., Rowland R.J. 1996. Cold acclimation and alterations in dehydrin-like and bark storage proteins in the leaves of sibling deciduous and evergreen peach. J. Amer. Soc. Hort. Sci. 121:915.919.

Arora R., Rowland L.J., Tanino K. 2003. Induction and release of bud dormancy in woody perennials: a science comes of age. HortScience 38: 911-921.

Artlip T.S., Callahan A.M., Bassett C.L., Wisniewski M.E. 1997. Seasonal expression of a dehydrin gene in sibling deciduous and evergreen genotypes of peach (Prunus persica [L.] Batsch). Plant Mol. Biol. 33: 61-70.

Baggiolini M., 1980: Stades reperes de la abricotier- Stades reperes de la pệcher. Stades reperes du ceresier - Stades reperes du prunier. ACTA. Guide pratique de defense des cultures, Paris.

Balandier P., Bonhomme M., Rageau R., Capitan F., Parisot E. 1993a. Leaf bud endodormancy release in peach trees: evaluation of temperature models in temperate and tropical climates. Agr. Forest Meteorol. 67: 95-113.

Ballester J., Company R.S., Arús P., De Vicente M.C. 2001. Genetic mapping of a major gene delaying blooming time in almond. Plant Breed. 120: 268-270.

Bassett C.L., Wisniewski M.E., Artlip T.S., Norelli J.L., Renaut J., Farrell R.E. 2006. Global analysis of genes regulated by low temperature and photoperiod in peach bark. J. Amer. Soc. Hort. Sci. 131 4: 551-563.

Bastow R., Mylne J.S., Lister C., Lippman Z., Martienssen R.A., Dean C. 2004. Vernalization requires epigenetic silencing of FLC by histone methylation. Nature 427: 164-167.

Baurle I., Dean C. 2006: The timing of developmental transitions in plants. Cell 125:, 655-664.

Becker A., Theißen G. 2003. The major clades of MADS-box genes and their role in the development and evolution of flowering plants. Mol. Phyl. Evol. 29: 464-489.

Benedict C., Skinner J.S., Meng R., Chang Y., Bhalerao R., Huner N.P.A., Finn C.E., Chen T.H.H., Hurry V. 2006. The CBF1-dependent low temperature signalling pathway, regulon, and increase in freeze tolerance are conserved in Populus spp. Plant Cell Environ. 29: 1259-1272.

Bentsink L., Soppe W., Koornneef M. 2007. Genetic aspects of seed dormancy. In: Bradford KJ, Nonogaki H. eds. Annual Plant Rev. 27: Seed Development, Dormancy and Germination. Oxford: Blackwell. pp: 113-132

Bielenberg D.G., Wang Y., Fan S., Reighard G.L., Scorza R., Abbott A.G. 2004. A deletion affecting several candidate genes is present in the evergrowing peach mutant. J. Hered. 95:436-444.

Bielenberg D.G., Wang Y., Li Z., Zhebentyayeva T., Fan S., Reighard G.L., Scorza R., Abbott A.G. 2008. Sequencing and annotation of the evergrowing locus in peach (Prunus persica [L.] Batsch) reveals a cluster of six MADSbox transcription factors as candidate genes for regulation of terminal bud formation. Tree Genet. Genomes 4 : 495-507.

Boerjan W., Ralph J., Baucher M. 2003. Lignin biosynthesis. Ann. Rev. Plant Biol. 54: 519-546. 
Böhlenius H., Huang T., Charbonnel-Campaa L., Brunner A.M., Jansson S., Strauss S.H., Nilsson O. 2006. CO/FT regulatory module controls timing of flowering and seasonal growth cessation in trees. Science. 312: 1040-1043.

Bolle C., Koncz C., Chua N.H. 2000. PAT1, a new member of the GRAS family, is involved in phytochrome A signal transduction. Genes \& Dev. 14:1269-1278.

Byrne D.H., Sherman W.B., Bacon T.A. 2000. Stone fruit genetic pool and its exploitation for growing under warm climatic conditions. In: Erez, A. (Ed.). Temperate Fruit Crops in warm Climates. Kluwer Academic Publishers. The Netherlands. pp: 157-230.

Cadman C.S.C., Toorop P.E., Hilbirst H.W.M., Finch-Savage W.E. 2006. Gene expression profiles of Arabidopsis Cvi seed during cycling through dormant and non-dormant states indicate a common underlying dormancy control mechanism. Plant J. 46: 805-822.

Campbell M., Segear E., Beers L., Knauber D., Suttle J. 2008. Dormancy in potato tuber meristems: chemically induced cessation in dormancy matches the natural process based on transcript profiles. Funct. Integr. Genomics 8: 317 328.

Campoy J.A., Ruiz D., Egea J. 2011a. Dormancy in temperate fruit trees in a global warming context: a review. Sci. Hortic. 130: 357-372.

Campoy J.A., Ruiz D., Egea J., Rees D.J.G., Celton J.M., Martinez-Gomez P. 2011b. Inheritance of flowering time in apricot (Prunus armeniaca L.) and analysis of linkage quantitative trait loci (QTLs) using simple sequence repeat (SSR) markers. Plant Mol. Biol. Rep. 29:404-410.

Carles C., Bies-Etheve N., Aspart L., Léon-Kloosterziel K.M., Koornneef M., Echeverria M., Delseny M. 2002. Regulation of Arabidopsis thaliana Em genes: role of ABI5. Plant J. 30: 373-383.

Cesaraccio C., Spano D., Snyder R.L., Duce P. 2004. Chilling and forcing model to predict bud burst of crop and forest species. Agr. Forest Meterol. 126: 1-13.

Champagnat P., Lavarenne S., Barnola P. 1975. Corrélations entre bourgeons et intensité de la dormance sur le rameau de l'année pour quelques vegétaux ligneux en repos apparent. C.R. Acad. Sc. Paris. 280, serie D, 2219-222.

Champagnat P. 1989. Rest and activity in vegetative buds of trees. Annales des Sciences Forestieres 46: (suppl.):9-26.

Chen D., Ding Y., Guo W., Zhang T. 2009: Molecular cloning and characterization of a flower-specific class III peroxidase gene in G. hirsutum. Mol. Biol. Rep. 36: 461-469.

Chiang G.C.K., Barua D., Kramer E.M., Amasino R.M., Donohue K. 2009. Major flowering time gene, FLOWERING LOCUS C, regulates seed germination in Arabidopsis thaliana. Proc. Natl. Acad. Sci. USA 106: 11661-11666.

Conesa A., Gotz S., Garcia-Gomez J.M., Terol J., Talon M., Robles M. 2005. Blast2GO: a universal tool for annotation, visualization and analysis in functional genomics research. Bioinformatics. 21:3674-3676.

Corbesier L., Coral V., Jang S., Fornara F., Fan O., Searle I., Giakountis A., Farrona S., Gissot L., Turnbull C., Coupland G. 2007. FT protein movement contributes to long distance signalling in floral induction of Arabidopsis. Science 316: 1030-1033.

Couvillon G.A., Erez A. 1985. Influence of prolonged exposure to chilling temperatures on bud break and heat requirement for bloom of several fruit species. J. Am. Soc. Hort. Sci. 110: 47-50.

Coville F.W. 1920 The influence of cold in stimulating the growth of plants. Proc. Natl. Acad. Sci. 6:434-435.

Davies Jr F.T. 1983. Breaking seed dormancy of 'Nemaguard' peach. HortScience 18: 959-965.

De Lucia F., Crevillen P., Jones A.M.E., Greb T., Dean C. 2008. A PHD-Polycomb Repressive Complex 2 triggers the epigenetic silencing of FLC during vernalization. Proc. Nat. Acad. Sci. USA 105: 16831-16836.

Derory J., Léger P., Garcia V., Schaeffer J., Hauser M.T., Salin F., Luschnig C., Plomion C., Glöss1 J., Kremer A. 2006. Transcriptome analysis of bud burst in sessile oak (Quercus petraea). New Phytol. 170: 723-738.

Dhanaraj A.L., Slovin J.P., Rowland L.J. 2004. Analysis of gene expression associated with cold acclimation in blueberry floral buds using expressed sequence tags. Plant Sci. 166: 863-872.

Dharmawardhana D.P., Ellis B.E., Carlson J.E. 1992. Characterization of vascular lignification in Arabidopsis thaliana. Can. J. Bot. 70: 2238-2244.

Diatchenko L., Lau Y.F.C., Campbell A.P., Chenchik A., Moqadam F., Huang B., Lukyanov S., Lukyanov K, Gurskaya N., Sverdlov E.D., Siebert P.D. 1996. Suppression subtractive hybridization: A method for generating differentially regulated or tissue-specific cDNA probes and libraries. Proc. Natl. Acad. Sci. USA 93: 6025-6030

Dijkwel P.P., Huijser C., Weisbeek P.J., Chua N.H., Smeekens S.C.M. 1997. Sucrose control of phytochrome A signalling in Arabidopsis. The Plant Cell Vol. 9: 583-595.

Dirlewanger E., Moing A., Rothan C., Svanella L., Pronier V., Guye A., Plomion C. Monet R. 1999. Mapping QTLs controlling fruit quality in peach (Prunus persica (L.) Batsch). Theor. Appl. Gen. 98: 18-31.

Downs R.J., Borthwick H.A. 1956. effects of photoperiod on growth of trees. Bot. Gaz. 117: 310-326.

Doyle M.R. \& Amasino R.M. 2009. A single amino acid change in the enhancer of zeste ortholog CURLY LEAF results in vernalization-independent, rapid flowering in Arabidopsis. Plant Physiol. 151: 1688-1697. 
Druart N., Johansson A., Baba K., Schrader J., Sjodin A., Bhalerao R.R., Resman L. Trygg J., Moritz T., Bhalerao R.P. 2007. Environmental and hormonal regulation of the activity-dormancy cycle in the cambial meristem involves stage-specific modulation of transcriptional and metabolic networks. Plant J. 50: 557-573.

Durgbanshi A., Arbona V., Pozo O., Miersch O., Sancho J.V., Gómez-Cadena A. 2005. Simultaneous determination of multiple phytohormones in plant extracts by liquid chromatography-electrospray tandem mass spectrometry. J. Agric. Food Chem. 53: 8437-8442.

Eagles C.G., Wareing P.F. 1963. Dormancy regulators in woody plants. Nature 199: 874-875.

Edwards G.R. 1987. Producing temperate-zone fruit at low latitudes - avoiding rest and chilling requirement. HortScience 22: 1236-1240.

Egea J., Ortega E., Martinez-Gomez P., Dicenta F. 2003. Chilling and heat requirement of almond cultivars for flowering. J. Environ. Exp. Bot. 50: 79-85.

Endo T., Shimada T., Fujii H., Kobayashi Y., Araki T., Omura M. 2005. Ectopic expression of an FT homolog from Citrus confers an early flowering phenotype on trifoliate orange (Poncirus trifoliata L. Raf.). Transgenic Res. 14: 703-712.

Erez A. 2000. Bud dormancy; phenomenon, problems and solutions in the tropics and subtropics. In: Erez, A. (Ed.) Temperate fruit crops in warm climates. Kluwer Academic Publishers, The Netherlands. pp: 17-48.

Erez A., Couvillon G.A., Hendershott C.H. 1979: Effect of cycle length on chilling negation by high-temperatures in dormant peach leaf buds. J. Am. Soc. Hort. Sci. 104, 573-576.

Erez A., Couvillon G. A. 1987. Characterization of the influence of moderate temperatures on rest completion in peach. J. Amer. Soc. Hort. Sci. 112: 677-680.

Erez A., Lerner H. 1990. Means to improve leafing using rest-avoidance technique in peaches in Israel. Acta. Hort. 279: 239-246.

Erez A., S. Fishman S., Linsley-Noakes G.C., Allan P. 1990: The Dynamic-model for rest completion in peach buds. Acta Hort. 276: 165-174.

Erez A., Faust M., Line R.M. 1998. Changes in water status in peach buds on induction, development and release from dormancy. Scientia Hort. 73: 111-123.

Ewing B., Green P. 1998. Base-calling of automated sequencer traces using phred. II error probabilities. Genome Res. 8:186-194.

Eriksson M.E. 2000. The role of phytochrome A and gibberellins in growth under long and short day conditions: studies in hybrid aspen. PhD tesis, Swedish Univ. Agric. Sci., Umeá, Sweden.

Fan S. 2010. Mapping quantitative trait loci associated with chilling requirement and bloom date in peach. PhD thesis dissertation. Clemson University (SC) USA.

Fan S., Bielenberg D.G., Zhebentyanyeva T.N., Reighard G.L., Okie W.R., Holland D., Abbott A.G. 2010. Mapping quantitative trait loci associated with chilling requirement, heat requirement and bloom date in peach (Prunus persica). New Phytol. 185:917-930.

Fankhauser C. \& Chory J. 1997. light control of plant development. Ann. Rev. Cell Dev. Biol. 3: 203-229

Faust M. 2000. Physiological considerations for growing temperate-zone fruit crops in warm climates. In: Erez A (Ed.) Temperate fruit crops in warm climates - Kluwer Academic Publishers, The Netherlands. pp 137-156.

Faust M., Liu D., Line M.J., Stutte G.W. 1995. Conversion of bound water to free water in endodormant buds of apple is an incremental process. Acta Hort. 395: 113-117

Fennel A., Line M.J. 2001. Identifying differential tissue response in grape (Vitis riparia) during induction od endodormancy using nuclear magnetic resonance imaging. J. Amer. Soc. Hort. Sci. 126; 681-688.

Ferres-Maso M., Sacilotto N., Lopez-Rodas G., Dagorn J.C., Iovanna J.L., Closa D., Folch-Puy E. 2009. PAP1 signaling involves MAPK signal transduction. Cell. Mol. Life Sci. 66: 2195-2204.

Finch-Savage W.E., Leubner-Metzger G. 2006. Seed dormancy and the control of germination. New Phytol. 171: 501523.

Finkelstein R., Reeves W., Ariizumi T., Steber C. 2008. Molecular aspects of seed dormancy. Ann. Rev. Plant Biol. 59: 387-415.

Finnegan E.J. Dennis E.S. 2007. Vernalization-induced trimethylation of histone H3 lysine 27 at FLC is not maintained in mitotically quiescent cells. Curr. Biol. 17: 1978-1983.

Finnegan E.J. et al., 2005. The downregulation of FLOWERING LOCUS C (FLC) expression in plants with low levels of DNA methylation and by vernalization occurs by distinct mechanisms. Plant J. 44: 420-432.

Finnegan E.J., Kovac K.A., Jaligot E., Sheldon C.C., Peacock W.J., Dennis E.S. 2005. The downregulation of FLOWERING LOCUS C (FLC) expression in plants with low levels of DNA methylation and by vernalization occurs by distinct mechanisms. Plant J. 44: 420-432.

Fishman S., Erez A., Couvillon G.A., 1987a. The temperature dependence of dormancy breaking in plants: mathematical analysis of a two-step model involving a cooperative transition. J. Theor. Biol. 124: 473-483. 
Fishman S., Erez A., Couvillon G.A., 1987b. The temperature dependence of dormancy breaking in plants: mathematical analysis of a two-step model involving a cooperative transition. J. Theor. Biol. 126: 309-321.

Flachowsky H. et al., Peil A., Sopanen T., Elo A., Hanke V. 2007. Overexpression of BpMADS4 from silver birch (Betula pendula Roth.) induces early flowering in apple (Malus x domestica Borkh.). Plant Breed. 126: 137-145.

Frewen B.E., Chen T.H.H., Howe G.T., Davis J., Rohde A., Boerjan W., Bradshaw H.D. Jr. 2000. Quantitative Trait loci and Candidate gene mapping of bud set and bud flush in Populus. Genetics 154: 837-845.

Frisby J.W., Seeley S.D. 1993. Chilling of endodormant peach propangules. I. Seed germination and emergence. J. Am. Soc. Hort. Sci. 118: 248-252.

Fuchigami L.H., Nee, C.C. 1987. Degree growth stage model and rest-breaking mechanism in temperate woody perennials. HortScience. 22:, 836-845.

Gardner R.A.W., Bertling I. 2005. Effect of winter chilling and paclobutrazol on floral bud production in Eucalyputs nitens. S. Afr. Bot. 71: 238-249.

Gariglio, N., González Rossia D.E., Mendow M., Reig C., Agustí M. 2006. Effect of artificial chilling on the depth of endodormancy and vegetative and flower budbreak of peach and nectarine cultivars using excised shoots. Sci. Hortic. 108:371-377.

Garner W.W., Allard H.A. 1923. Further studies in photoperiodism. The response of the plant to relative length of day and night. J. Agric. Res. 23: 871-920.

Gentleman R.C., Carey V.J., Bates D.M., Bolstad B., Dettling M., Dudoit S., Ellis B., Gautier L., Ge Y., Gentry J., Hornik K., Hothorn T., Huber W., Iacus S., Irizarry R., Leisch F., Li C., Maechler M., Rossini A.J., Sawitzki G., Smith C., Smyth G., Tierney L., Yang J.Y., Zhang J.. 2004. Bioconductor: open software development for computational biology and bioinformatics. Genome Biol. 5:R80.

Gilmour S.J., Selbot A.M., Salazar M.P., Everard J.D., Thomashow M.F. 2000. Overexpression of the Arabidopsis CBF3 transcriptional activator mimics multiple biochemical changes associated with cold acclimation. Plant Physiol. 124: 1854-1865.

Giraudat J., Hauge B.M., Valon C., Smalle J., Parcy F., Goodman H.D. 1992. Isolation of the Arabidopsis ABI3 gene by positional cloning. Plant Cell 4: 1251-1261.

Gómez-Porras J.L., Riaño-Pachón D.M., Dreyer I., Mayer J.E., Mueller-Roeber B. 2007. Genome-wide analysis of ABA-responsive elements ABRE and CE3 reveals divergent patterns in Arabidopsis and rice. BMC Genomics 8: 260.

Guttridge CG. 1985. Fragaria $\times$ ananassa. In: Halevy A (ed.). CRC Handbook of Flowering. Vol III.: p 16-33. CRC Press, Boca Raton.

Halaly T., Pang X., Batikoff T., Crane O., Keren A., Venkateswari J., Ogrodovitch A., Sadka A., Lavee S., Or E. 2008. similar mechanisms might be triggered by alternative external stimuli that induce dormancy release in grape buds. Planta 228: 79-88.

Hänninen H. 1995. Effects of climatic change on trees from cool and temperate regions: an ecophysiological approach to modelling bud burst phenology. Can. J. Bot. 73: 183-199.

Hara M., Terashima S., Fukaya T., Kuboi T. 2003. Enhancement of cold tolerance and inhibition of lipid peroxidation by citrus dehydrin in transgenic tobacco. Planta 217: 290-298.

Hara M., Fujinaga M., Kuboi T. 2004. Radical scavenging activity and oxidative modification of citrus dehydrin. Plant Physiol. Biochem. 42: 657-662.

Hartmann H.T., Kester D.E., Davies F.T., Geneve R.L. 2011. Hartmann \& Kester's plant propagation: principles and practices. Upper Saddle River: Prentice Hall. pp. 230.

Hauagge R., Cummins J.N. 1991. Genetics of length of dormancy period in Malus vegetative buds. J. Am. Soc. for Hort. Sci. 116: 121-126.

Hedley P.E., Russell J.R., Jorgensen L., Gordon S., Morris J.A., Hackett C.A., Cardle L. Brennan R. 2010. Candidate genes associated with bud dormancy release in blackcurrant (Ribes nigrum L.). BMC Plant Biology 10: 202-215.

Heide O.M. 1977. Photoperiod and temperature interactions in growth and flowering of strawberry. Physiol. Plant. 40, 21-26.

Heide O.M. 1993: Daylength and thermal time responses of budburst during dormancy release in some northern deciduous trees. Physiol. Plant. 88: 531-540.

Heide O.M., Prestrud A.K. 2005. low temperature, but not photoperiod, controls growth cessation and dormancy induction and release in apple and pear. Tree Physiol. 25: 109-114.

Hemberg T. 1949. Growth-inhibiting substances in terminal buds of Fraxinus. Physiol. Plant. 2: 37-44.

Hemming M.N., Fieg S., Peacock W.J., Trevaskis B. 2009. Region associated with repression of barley (Hordeum vulgare) VERNALIZATION1 gene are not required for cold induction. Mol. Genet. Genomics 282: 107-117.

Hemming M.N., Trevaskis B. 2011. Make hay when the sun shines: The role of MADS-box genes in temperaturedependant seasonal flowering responses. Plant Science 180: 447-453. 
Hennig L., Derkacheva M. 2009. Diversity of Polycomb group complexes in plants: same rules, different players?. Trends in Genetics 25: 414-423.

Heo J.B., Sung S. 2011. Vernalization-mediated epigenetic silencing by a long intronic noncoding RNA. Science 331: 76-79.

Higo K., Ugawa Y., Iwamoto M., Korenaga T. 1999. Plant cis-acting regulatory DNA elements (PLACE) database:1999. Nucleic Acids Res 27: 297-300.

Hishiya A., Iemura S., Natsume T., Takayama S., Ikeda K. \& Watanabe K. 2006. A novel ubiquitin-binding protein ZNF216 functioning in muscle atrophy. The EMBO Journ. 25: 554-564.

Hoenicka H., Nowitzki O., Hanelt D., Fladung M. 2008. Heterologous overexpression of the birch FRUITFULL-like MADS-box gene BpMADS4 prevents normal senescence and winter dormancy in Populus tremula L. Planta 227: 1001-1011.

Holdsworth M.J., Bentsink L., Soppe W.J.J. 2008. Molecular networks regulating Arabidopsis seed maturation, afterripening, dormancy and germination. New Phytol. 179: 33-54.

Horvath D.P. 2009. Common mechanisms regulate flowering and dormancy. Plant Sci. 177: 523-531.

Horvath D.P., Chao W.S., Anderson J.V. 2002. Molecular analysis of signals controlling dormancy and growth in underground adventitious buds of leafy spurge. Plant Physiol. 128: 1439-1446.

Horvath D.P., Anderson J.V., Chao W.S., Foley M E. 2003. Knowing when to grow: signals regulating bud dormancy. Trends in Plant Sci. 8: 534-540.

Horvath D.P., Chao W.S., Suttle J.C., Thimmapuram J., Anderson J.V. 2008. Transcriptome analysis identifies novel responses and potential regulatory genes involved in seasonal dormancy transitions of leafy spurge (Euphorbia esula L.). BMC Genomics 9: 536.

Horvath D.P., Sung S., Kim D., Chao W., Anderson J.V. 2010. Characterization, expression and function of DORMANCY ASSOCIATED MADS-BOX genes from leafy spurge (Euphorbia esula L.). Plant Mol. Biol. 73: 169-179.

Huang J., Teng L., Li L., Chen D., Xu L.G., Zhai Z. \& Shu H.B. 2004. ZNF216 is an A20-like and IkB kinase $\gamma$ interacting inhibitor of NFkB activation. Journ. Biol. Chem. 279: 16847-16853.

Huang, X., Madan A. 1999. CAP3: A DNA sequence assembly program. Genome Res. 9:868-877.

Ibañez C., Ramos A., Acebo P., Contreras A., Casado R., Allona I., Aragoncillo C. 2008. Overall alteration of circadian clock gene expression in the chestnut cold response. PlonOne 3: 3567-3575.

Ingram J., Bartels D. 1996. The molecular basis of dehydration tolerance in plants. Ann. Rev Plant Physiol. Plant Mol. Biol. 47: 377-403.

Ito A., Hayama H., Kashimura Y. 2002. Sugar metabolism in buds during flower bud formation: a comparison of two Japanese pear (Pyrus pyrifolia (Burm.) Nak.) cultivars possessing different flowering habits. Sci. Hort. Vol 96: $163-175$.

Ito H., Saito T. 1962. Studies on the flower formation in the strawberry plants. I. Effects of temperature and photoperiod on the flower formation. Tohoku J. Agric. Res. 13: 191-203.

Itoh H., Nonoue Y., Yano M., Izawa T. 2010. A pair of floral regulators sets critical day length for $H d 3 a$ florigen expression in rice. Nature genetics 42: 635-639.

Izawa T., Oikawa T., Sugiyama N., Tanisaka T., Yano M., Shimamoto K. 2002. Phytochrome mediates the external light signal to repress FT orthologs in photoperiodic flowering in rice. Genes \& Dev. 16: 2006-2020.

Izawa T. Daylenght measurement by rice plants in photoperiodic short-day flowering. 2007 Int. Rev. Cytology 256: $191-222$.

Jaglo-Ottosen K.R., Gilmour S.J., Zarka D.G., Schabenberger O., Thoomashow M.F. 1998. Arabidopsis CBF1 overexpression induces COR genes and enhances freezing tolerance. Science 280: 104-106.

Janick J. 1974. The apple in Java. Horstscience 9: 13-15.

Jia Y, Anderson JV, Horvath DP, Gu YQ, Lym RG, Chao WS. 2006. Subtractive cDNA libraries identify differentially expressed genes in dormant and growing buds of leafy spurge (Euphorbia esula). Plant Mol. Biol. 61: 329-344.

Jian L.C., Li P.H., Sun L.H., Chen T.H.H. 1997. Alterations in ultrastructure and subcellular localization of Ca ${ }^{2+}$ in polar apical bud cells during the induction of dormancy. J. Exp. Bot. 48: 1195-1207.

Jiménez S., Lawton-Rauh A.L., Reighard G.L., Abbott A.G., Bielenberg D.G. 2009. Phylogenetic analysis and molecular evolution of the dormancy associated MADS-box genes from peach. BMC Plant Biology 9: 81-93.

Jiménez S., Li Z., Reighard G.L., Bielenberg D. G. 2010a. Identification of genes associated with growth cessation and bud dormancy entrance using a dormancy-incapable mutant. BMC Plant Biology. 10: 25-36..

Jiménez S., Reighard G.L., Bielenberg D.G. 2010b. Gene expression of DAM5 and DAM6 is suppressed by chilling temperatures and inversely correlated with bud break rate. Plant Mol. Biol. 73: 157-167.

Jung C., Seo J.S., Han S.W., Koo Y.J., Kim C.H., Song S.I., Nahm B.H., Choi Y.D., Cheong J.J. 2008. Overexpression of AtMYB44 enhances stomatal closure to confer abiotic stress tolerance in transgenic Arabidopsis. Plant Physiol. 146: 623-635. 
Karsai I, Szucs P., Mészáros K., Filichkina T., Hayes P.M., Skinner J.S., Lang L., Bedö Z., 2005. The Vrn-H2 locus is a major determinant of flowering time in a facultative $\mathrm{x}$ winter growth habit barley (Hordeum vulgare $\mathrm{L}$.) mapping population. Theor. Appl. Genet. 110:1458-1466.

Kasuga M., Liu Q., Miura S., Yamaguchi.Shinozaki K., Shinozaki K. 1999. Improving plant drough salt, and freezing tolerance by gene transfer of a single stress-inducible transcription factor. Nat. Biotechnol. 17: 287-291.

Keilin T., Pang X., Venkateswari J., Halaly T., Crane O., Keren A., Ogrodovtich A., Ophir R., Volpin H., Galbraith D., Or E. 2007. Digital expression profiling of a grape-bud EST collection leads to new insight into molecular events during grape-bud dormancy release. Plant Sci. Vol. 173: 446-457.

Kester D.E. 1969. Pollen effects on chilling requirements of almond and almond hybrid seeds. J Am. Soc. Hort. Sci. 94 : 318-321.

Kester D.E., Raddi P., Asay R. 1977. Correlations of chilling requirements for germination, blooming and leafing within and among seedling populations of almond. J. Am. Soc. Hort. Sci. 102: 145-148.

Kim H.J., Kim Y.K., Park J.Y., Kim J. 2002. Light signalling mediated by phytochrome plays an important role in coldinduced gene expression through the C-repeat dehydration responsive element (C/DRE) in Arabidopsis thaliana. Plant J. 29: 693-704.

Koike M., Takezawa D., Arakawa K., Yoshida S. 1997. Accumulation of 19-kDa plasma membrane polypeptide during induction of freezing tolerance in wheat suspension-cultured cells by abscisic acid. Plant \& Cell Physiol. 38: 707-716.

Koussa T., Zaoui D., Broquedis M. 1998. Relationship between the levels of abscisic acid in latent buds, in leaves and in internodes of Vitis vinifera cv. Merlot during the dormancy phase. J. International des sciences de la Vigne et du Vin 32: 203-210.

Kramer P.J. 1936. Effect of variation in length of day on growth and dormancy of trees. Plant Physiol. 11: $127-137$.

Kucera B., Cohn M.A., Leubner-Metzger G. 2005. Plant hormone interactions during seed dormancy release and germination. Seed Sci. Res. 15: 281-307.

Kuroda H. and Sagisaka S. 1993. Ultrastructural changes in cortical cells of apple (Malus pumila Mill.) associated with cold hardiness. Plant cell Physiol. 34: 357-365.

Kwong R.W., Bui A.Q., Lee H., Kwong L.W., Fishcher R.L., Goldberg R.B., Harada J.J. 2003. LEAFY COTILEDON1-LIKE defines a class of regulators essential for embryo development. Plant Cell 15: 5-18.

Lang, G.A. 1987. Dormancy: a new universal terminology. HortScience. 22:817-820.

Lang G.A., Early J.D., Martin G.C., Darnell R.L. 1987. Endo- para- and ecodormancy: physiological terminology and classification for dormancy research. HortScience. 22: 371-377.

Lee H., Fischer R.L., Goldberg R.B., Harada J.J. 2003. Arabidopsis LEAFY COTYLEDON1 represents a functionally specialized subunit of the CCAAT binding transcription factor. Proc. Natl. Acad. Sci. USA 100: 2152-2156.

Lee S.J., Lee E.J., Yang E.J., Lee J.E., Park A.R., Song W.H., Park O.K. 2004. Proteomic identification of annexins, calcium-dependent membrane binding proteins that mediate osmotic stress and abscisic acid signal transduction in Arabidopsis. Plant Cell 16: 1378-1391.

Lee S.J., Kang J.Y., Park H.J., Kim M.D., Bae M.S., Choi H.I., Kim S.Y. 2010. DREB2C interacts with ABF2, a bZIP protein regulating abscisic acid-responsive gene expression, and its overexpression affects abscisic acid sensitivity. Plant Physiol. 153: 716-727.

Legave J.M., García M., Marco F. 1982. Some descriptive aspects of drops process of flower buds or young flowers on apricot in south of France. Acta Hort. 121: 75-83.

Leida C., Terol J., Martí G., Agustí M., Llácer G., Badenes M.L., Ríos G. 2010. Identification of genes associated with bud dormancy release in Prunus persica by suppression subtractive hybridization. Tree Physiol. 30: 655-666.

Leida C., Conesa A., Llácer G., Badenes M.L., Ríos G. 2012. Histone modifications and expression of DAM6 gene in peach are modulated during bud dormancy release in a cultivar-dependent manner. New Phytol. 193: 67-80.

Leubner-Metzger G., Fründt C., Meins Jr. F. 1996. Effects of gibberellins, darkness and osmotica on endosperm rupture and class I $\beta$-1,3-glucanase induction in tobacco seed germination. Planta 199:282-288.

Lewis R.S., Kernodle S.P. 2009. A method for accelerated trait conversion in plant breeding. Theor. Appl. Genet. 118: 1499-1508.

Li Z., Reighard G.L., Abbott A.G., Bielenberg G. 2009. Dormancy-associated MADS genes from the EVG locus of peach [Prunus persica (L.) Batsch] have distinct seasonal and photoperiodic expression patterns. J. Exp. Bot. 60: 3521-3530.

Linsley-Noakes G. C., Allan P. 1994: Comparison of two models for the prediction of rest completion in peaches. Sci. Hort. 59, 107-113.

Liu Q., Kasuga M., Sakuma Y., Abe H., Miura S., Yamaguchi-Shinozaki K., Shinozaki K. 1998. Two transcription factors, DREB1 and DREB2, with an EREBP/AP2 DNA binding domain separate two cellular signal transduction pathways in drought- and low-temperature-responsive gene expression, respectively, in Arabidopsis. Plant Cell 10: 1391-1406. 
Liu Y., Koornneef M., Soppe W.J.J. 2007. The Absence of Histone H2B Monoubiquitination in the Arabidopsis hub1 (rdo4) Mutant Reveals a Role for Chromatin Remodelling in Seed Dormancy. The Plant Cell. 19:433-444.

Liu Y., Geyer R., van Zanten M., Carles A., Li Y., Hörold A., Van Nocker S., Soppe W.J.J. 2011. Identification of the Arabidopsis REDUCED DORMANCY 2 gene uncovers a role for the polymerase associated factor 1 complex in seed dormancy. PLoS One 6: 22241-22249.

Liu Y.G., Ye N.H., Liu R., Chen M., Zhang J. 2010. $\mathrm{H}_{2} \mathrm{O}_{2}$ mediates the regulation of ABA catabolism and GA biosynthesis in Arabidopsis seed dormancy and germination. J. Exp. Bot. 61: 2979-2990.

Lloyd G., McCown B. 1981. Commercially feasible micropropagation of mountain laurel, Kolmia latifolia, by use of shoot tip culture. Comb. Proc. Inter. Plant Prop. Soc. 30: 421-427.

Lopez-Molina L., Mongrand S., Kinoshita N., Chua N.H. 2003. AFP is a novel negative regulator of ABA signaling that promotes ABI5 protein degradation. Genes \& Dev. 17: 410-418.

Luedeling E., Zhang M.H., McGranahan G., Leslie C. 2009. Validation of winter chill models using historic records of walnut phenology. Agr. Forest Metereol. 149: 1854-1864.

Luedeling E., Girvetz E.H., Semenov M.A., Brown P.H. 2011. Climate Change Affects Winter Chill for Temperate Fruit and Nut Trees. Plos One vol 6: n 5 e20155-20168.

Martínez-Gómez P., Dicenta F. 2001. Mechanisms of dormancy in seeds of peach (Prunus persica (L.) Batsch) cv. GF305. Sci. Hort. 91: 51-58.

Martz F., Kiviniemi S., Palva E.T., Sutinen M.L. 2006. Contribution of omega-3 fatty acid Desaturase and 3-ketoacylACP synthase II (KASII) genes in the modulation of glycerolipid fatty acid composition during cold acclimation in birch leaves. J. Exp. Bot. 57: 897-909.

Mathiason K, He D, Grimplet J, Venkateswari J, Galbraith DW, Or E., Fennel A.. 2009. Transcript profiling in Vitis riparia during chilling requirement fulfillment reveals coordination of gene expression patterns with optimized bud break. Funct. Integr. Genomics 9: 81-96.

Mazzitelli L., Hancock R.D., Haupt S., Walker P.G., Pont S.D.A., McNicol J., Cardle L., Morris J., Viola R., Brennan R., Hedley P.E., Taylor M.A. 2007. Co-ordinated gene expression during phases of dormancy release in raspberry (Rubus idaeus L.) buds. J. of Exp. Bot. 58: 1035-1045.

McCarty D.R. 1995. Genetic control and integration of maturation and germination pathways in seed development. Ann. Rev. Plant. Physiol. Biochem. 36: 83-89.

McCarty D.R., Hattori T., Carson C.B., Vasil V., Lazar M., Vasil I. K.. 1991. The viviparous-1 developmental gene of maize encodes a novel transcriptional activator. Cell 66: 895-905.

Mehlenbacher S.A., Voordeckers A.M. 1991. Relationship of flowering time, rate of seed germination, and time of leaf budbreak and usefulness in selecting for late-flowering apples. J. Am. Soc. Hort. Sci. 116: 565-568.

Mielke E.A., Dennis Jr. F.G. 1978. Hormonal control of flower bud dormancy in sour cherry (Prunus cerasus L.). III. Effects of leaves, defoliation and temperature on levels of abscisic acid in flower primordial. Journal Am. Soc. Hort. Sci. 103: 446-449.

Monet, R., Bassi D. 2008: Botany and Taxonomy. In: D. R. Layne, and D. Bassi (eds.), The peach botany, production and uses, 106-138. CABI, Wallingford, Oxfordshire, UK CABI pp:106-138.

Montaner D., Tárraga J., Huerta-Cepas J., Burguet J., Vaquerizas J.M., Conde L., Minguez P., Vera J., Mukherjee S., Valls J., Pujana M.A.G, Alloza E., Herrero J., Al-Shahrour F., Dopazo J., et al. 2006. Next station in microarray data analysis: GEPAS. Nucl. Ac. Res. 34: 486-491.

Mukhopadhyay A., Vij S., Tyagi A.K. 2004. Overexpression of a zinc-finger protein gene from rice confers tolerance to cold, dehydration, and salt stress in transgenic tobacco. Proc. Nat. Ac. Sci. USA 101: 6309-6314.

Murray M.B., Cannell M.G.R., Smith R.I. 1989: Date of budburst of 15 tree species in Britain following climatic warming. J. Appl. Ecol. 26:, 693-700.

Nakamura S., Lynch T.J., Finkelstein R.R. 2001. Physical interactions between ABA response loci of Arabidopsis. Plant J. 26: 627-635.

Nakashima K., Yamaguchi-Shinozaki K. 2006. Regulons involved in osmotic- and cold-stress-responsive gene expression in plants. Phytol. Plant 126: 62-71.

Nanjo T., Futamura N., Nishiguchi M., Igasaki T., Shinozaki K., Shinohara K. 2004. Characterization of full-length enriched expressed sequence tags of stress-treated polar leaves. Plant Cell Physiol. 45: 1738-1748.

Nir G., Shulman Y, Fanberstein L. Lavee S. 1986. Changes in the activity of catalase in relation to the dormancy of grapevine (Vitis vinifera L.) buds. Plant Physiol. 81:1140-1142.

Nitsch J.P. 1957. Growth responses of woody plants to photoperiodic stimuli. Proc. Ameri. Soc. Hort. Sci. 70: $512-525$.

Noll G.A., Fontanellaz M.E., Ruping B., Ashoub A., van Bel A.J.E., Fischer R., Knoblauch M., Prüfer D. 2007. Spatial and temporal regulation of the forisome gene for 1 in the phloem during plant development. Plant Mol. Biol. 65:285-294. 
North H., Baud S., Debeaujon I., Dubos C., Dubreucq B., Grappin P., Jullien M., Lepiniec L., Marion-Poll A., Miquel M., Rajjou L., Routaboul J.M., Caboche M. 2010. Arabidopsis seed secrets unravelled after a decade of genetic and omics-driven research. Plant J. 61: 971-981.

Nylander M., Svensson J., Palva E.T., Welin B.V. 2001. Stress induced accumulation and tissue-specific localization of dehydrins in Arabidopsis thaliana. Plant Mol. Biol. 45: 263-279

Ogundiwin E.A., Martí C., Forment J., Pons C., Granell A., Gradziel T.M. Peace C.P., Crisosto C.H. 2008. Development of ChillPeach genomic tools and identification of cold-responsive genes in peach fruit. Plant Mol. Biol. 68: 379-397.

Okie W.R. 1998. Preliminary descriptions of five new peach genes. Acta Hort. 465:, 107-110.

Okubo, H. 2000. Growth cycle and dormancy in plants. In: eds., J.D. Viemont and J. Crabbe. Dormancy in plants. New York, USA: CABI Publishing. pp: 1-22.

Oliver S.N., Finnegan E.J., Dennis E.S., Peacock W.J., Trevaskis B. 2009. Vernalization-induced flowering in cereals is associated with changes in histone methylation at the VERNALIZATION1 gene. Proc. Natl. Acad. Sci. 109: 8386-8391.

Olsen J.E., Juntilla O., Nilsen J., Eriksson M.E., Martinussen I., Olsson O., Sandberg G., Moritz T. 1997. Ectopic expression of oat phytochrome A in hybrid aspen changes critical daylenght fro growth and prevents cold acclimation. Plant J. 12: 1339-1350.

Olukolu B.A., Trainin T., Fan S., Kole C., Bielenberg D.G., Reighard G.L., Abbott A.G., Holland D. 2009. Genetic linkage mapping for molecular dissection of chilling requirement and budbreak in apricot (Prunus armeniaca L.). Genome 52: 819-828.

Or E., Vilozny I., Fennel A., Eyal Y., Ogrodovitch A. 2002. Dormancy in grape buds: isolation and characterization of catalase cDNA and analysis of its expression following chemical induction of bud dormancy release. Plant Sci. 162:121-130.

Oukabli A., Mahhou A. 2007. Dormancy in sweet cherry (Prunus avium L.) under Mediterranean climatic conditions. Biotechnol. Agron. Soc. Environ. 11: 133-139.

Pacey-Miller T., Scott K., Ablett E., Tingey S., Ching A., Henry R. 2003. Genes associated with the end of dormancy in grapes. Funct. Integr. Genomics 3: 144-152.

Pasternak G., Powell L.E. 1980. Chilling requirements of apple seeds from cultivars having low and high chilling requirements for shoot growth. HortScience 15: 408.

Pawasut A., Fujishige N., Yamane K., Yamaki, Y., Honjo H., 2004. Relationships between chilling and heat requirement for flowering in ornamental peaches. J. Jpn. Soc. Hort. Sci. 73:, 519-523.

Pelissier H.C., Peters W.S., Collier R., van Bel A.J.E., Knoblauch M. 2008. GFP tagging of Sieve Element Occlusion (SEO) proteins results in green fluorescent forisomes. Plant Cell Physiol. 49:1699-1710.

Peña L., Martin-Trillo M., Juarez J., Pina J.A:, Navarro L., Martinez-Zapater J.M. 2001. Constitutive expression of Arabidopsis LEAFY or APETALA1 genes in citrus reduces their generational time. Nat. Biotechnol. 19: 263267.

Pérez, F.J., R. Vergara R., and S. Rubio S. 2008. $\mathrm{H}_{2} \mathrm{O}_{2}$ is involved in the dormancy-breaking effect of hydrogen cyanamide in grapevine buds. Plant Growth Regul. 55:149-155.

Perry T.O. 1971. Dormancy of trees in winter. Science 171: 29-36.

Pollock B.M. 1962. Temperature control of physiological dwarfing in peach seedlings. Plant Physiol 37: $190-197$.

Powell L.E. 1987. Hormonal aspects of bud and seed dormancy in temperate-zone woody plants. HortScience 22: 845850.

Puhakainen T., Hess M.W., Mäkela P., Svensson J., Heino P., Palva E.T. 2004. Overexpression of multiple dehydrin genes enhances tolerance to freezing stress in Arabidopsis. Plant Mol. Biol 54: 743-753.

Ramos A., Pèrez-Solís Estefania, Ibañez C., Casado R., Collada C., Gómez L., Aragoncillo C., Allona I. 2005. Winter disruption of the circadian clock in chestnut. 2005. Proc. Natl. Acad. Sci. 102: 7035-7042.

Renaut J., Lutts S., Hoffman L., Hausman J.F. 2004. Responses of poplar to chilling temperatures: proteomic and physiological aspects. Plant Biol. 6: 81-90.

Richardson E.A., Seeley S.D., Walker D.R. 1974. A model for estimating the completion of rest in "Redhaven" and "Elberta" peach trees. HortScience 1: 331-332.

Rinne P.L.H:, Tuominen H., Juntilla O. 1994. Seasonal changes in bud dormancy in relation to bud morphology, water and starch content, and abscisic acid concentration in adult trees of Betula pubescens. Tree Physiol. 14: 549-561.

Rinne P.L.H., Welling A., Kaikuranta P. 1998. Onset of freezing tolerance in birch Betula pubescens involves LEA proteins and osmoregulation and is impaired in an ABA-deficient genotype. Plant Cell and Environ. 20: 11991204.

Rinne P.L.H., Kaikuranta P.M., Van der Schoot C. 2001. The shoot apical meristem restores its symplastic organization during chilling-induced release from dormancy. The Plant J. 26: 249-264. 
Rinne P.L.H., Van der Schoot C. 2003. Plasmodesmata at the crossroads between development, dormancy and defense. Can. J. Bot. 81: 1182-1197.

Rinne P.L.H., Welling A., Vahala J., Ripel L., Ruonala R., Kangasjärvi J., Van der Schoot C. 2011. Chilling of dormant buds hyperinduces FLOWERING LOCUS $\mathrm{T}$ and recruits GA-Inducible 1,3- $\beta$-glucanases to reopen signal conduits and release dormancy in Populus. Plant Cell

Ríos, G., Naranjo M.A., Iglesias D.J., Ruiz-Rivero O., Geraud M., Usach A., Talón M. 2008. Characterization of hemizygous deletions in Citrus using array-Comparative Genomic Hybridization and microsynteny comparisons with the poplar genome. BMC Genomics. 9:381.

Rodriguez J.A., Sherman W.B., Scorza R., Wisniewski M., Okie W.R. 1994. 'Evergreen' peach, its inheritance and dormant behavior. J. Amer. Soc. Hort. Sci. 119: 789-792.

Rohde A., Howe G.T., Olsen J.E., Moritz T., Van Montagu M., Juntilla O., Boerjan W. 2000. Molecular aspects of bud dormancy in trees: In: Jain S.N., Minocha S.C. (eds.). Molecular Biology of Woody Plants. Flower Academic Publishers, Dordrecht 89-134.

Rohde A., Prinsen E., De Rycke R., Engler G., Van Montagu M., Boerjan W. 2002. PtABI3 impinges on the growth and differentiation of embryonic leaves during bud set in poplar. Plant Cell 14: 1885-1901.

Rohde A., Bhalerao R.P. 2007. Plant dormancy in the perennial context. Trends Plant Sci. 12: 217-223.

Rohde A., Ruttinik T., Hostyn V., Sterck L., Van Driessche K., Borjen W. 2007. Gene expression during the induction, maintenance, and release of dormancy in apical buds of poplar. J. of Exp. Bot. 58: 4047-4060.

Rohde A., Storme V., Jorge V., Gaudet M., Vitacolonna N., Fabbrini F., Ruttink T., Zaina G., Marron N., Dillen S., Steenackers M., Sabatti M., Morgante M., Boerjan W., Bastien C. 2011. Bud set in poplar- genetic dissection of a complex trait in natural and hybrid populations. New Phytol. 189:106-121.

Rowland L.J., Arora R. 1997. Proteins related to endodormancy (rest) in woody perennials. Plant Sci. 126: $119-144$.

Rowland L.J., Ogden E., Arora R., Lim C.C., Lehman J.S., Levi A., Panta G.R., 1999. Use of blueberry to study genetic control of chilling requirement and cold hardiness in woody plants. HortScience 37: 1185-1191.

Ruiz D., Campoy J.A., Egea J. 2007. Chilling and heat requirements of apricot cultivars for flowering. Environ. J. Exp. Bot. 61: 254-263.

Ruonala R., Rinne P.L.H., Bangour M., Moritz T., Tuominen H., Kangasjarvi J. 2006. Transitions in the functioning of the shoot apical meristem in birch (Betula pendula) involve ethylene. Plant J. 46: 628-640.

Ruttink T., Arend M., Morreel K., Storme V., Rombauts S., Bhalerao R., Boerjan W., Rohde A. 2007. A molecular timetable for apical bud formation and dormancy induction in poplar. The Plant Cell 19: 2370-2390.

Sagisaka S. 1991. Occurrence of unidentified bodies that resemble "plastid initials" in poplar cells after breaking of dormancy in midwinter. Trees - Structure and function . Vol. 5 (3): 143-148.

Saleh A., Alvarez-Venegas R., Avramova Z. 2008. An efficient chromatin immunoprecipitation (ChIP) protocol for studying histone modifications in Arabidopsis plants. Nature Protocols 3: 1018-1025.

Salzman, R.A., Fujita T., Zhu-Salzman K., Hasegawa P.M., Bressan R.A. 1999. An improved RNA isolation method for plant tissues containing high levels of phenolic compounds or carbohydrates. Plant Mol. Biol. Reptr. 17:1117.

Samish R.M., Lavee S. 1962. The chilling requirements of fruit trees. In: Proc. XVI Int. Hort. Cong. Vol 5: $372-388$.

Samish R.M. 1954. Dormancy in woody plants. Annu.Rev. Plant Physiol. 5: 183-203.

Sánchez-Pérez R., Howad W., Dicenta F., Arús P., Martínez-Gómez P. 2007. Mapping major genes and quantitative trait loci controlling agronomic traits in almond. Plant Breed.ing 126, 310-318.

Sandoval J., Rodríguez J.L., Tur G., Serviddio G., Pereda J., Boukaba A., Sastre J., Torres L., Franco L., López-Rodas G. 2004. RNAPol-ChIP: a novel application of chromatin immunoprecipitation to the analysis of real-time gene transcription. Nucl. Ac. Res. 32: e88.

Sasaki R., Yamane H., Ooka T., Jotatsu H., Kitamura Y., Akagi T., Tao R. 2011. Functional and expressional Analyses of PmDAM genes associated with endodormancy in Japanese apricot. Plant Physiol. 157: 485-497.

Sasani S., Hemming M.N., Oliver S.N., Greenup A., Tavakkol-Afshari R., Mahafoozi S., Poustini K., Sharifi H., Dennis E.S., Peacock W.J., Trevaskis B. 2009. The influence of vernalization and daylenght on expression of flowering-time genes in the shoot apex and leaves of barley (Hordeum vulgare L.). J. Exp. Bot. 60: 2169-2178.

Saure M.C. 1973. Successful apple growing in Indonesia. Fruit Var. J. 27: 44-45.

Saure M.C. 1985. Dormancy release in deciduous fruit trees. Hort. Rev. 7: 239-300.

Scalabrelli, G., Viti R., Cinelli F. 1991. Change in catalase activity and dormancy of apricot buds in response to chilling. Acta Hort. 293:267-274.

Schmitz R.J., Sung S., Amasino R. 2008, Histone arginine methylation is required for vernalization induced epigenetic silencing of FLC in winter-annual Arabidopsis thaliana. Proc. Natl. Acad. Sci. Usa 105:411-416.

Schrader J., Baba K., May S.T., Palme K., Bennet M., Balherao R.P. Sandberg G. 2003.Polar auxin transport in the wood-forming tissues of hybrid aspen is under simultaneous control of developmental and environmental signals. Proc. Natl. Acad. Sci USA 100: 10096-10101. 
Schrader J., Moyle R., Bhalerao R., Hertzberg M., Lundeberg J., Nilsson P., Bhalerao R.P. 2004. Cambial meristem dormancy in trees involves extensive remodelling of the transcriptome. The Plant J. 40: 173-187.

Searle I., He Y., Turck F., Vicent C., Fornara F., Kröber S., Amasino R.A., Coupland G. 2006. The transcription factor FLC confers a flowering response to vernalization by repressing meristem competence and systemic signalling in Arabidopsis. Genes \& Dev. 2006 vol. 20: 898-912.

Sheldon C.C., Rouse D.T., Finnegan E.J., Peacock W.J. et al., Dennis E.S. 2000. The molecular basis of vernalization: the central role of FLOWERING LOCUS C activity as a mechanism for the evolution of summer annual flowering behaviour in Arabidopsis. Proc. Natl. Acad. Sci. USA 97: 3753-3758.

Short T.W. 1999. Overexpression of Arabidopsis phytochrome B inhibits Phytochrome A function in presence of sucrose. Am. Soc. Plant Physiol. 119: 1497-1506.

Silva C., Gacia-Más J., Sánchez A.M., Arús P., Oliveira M.M. 2005. Looking into flowering time in almond (Prunus dulcis (Mill) D. A. Webb): the candidate gene approach. Th. Appl. Gen. 110: 959-968.

Stajich J.E., Block D., Boulez K., Brenner S.E., Chervitz S.A., Dagdigian C., Fuellen G., Gilbert J.G., Korf I., Lapp H., Lehväslaiho H., Matsalla C., Mungall C.J., Osborne B.I., Pocock M.R., Schattner P., Senger M., Stein L.D., Stupka E., Wilkinson M.D. Birney E. 2002. The Bioperl toolkit: Perl modules for the life sciences. Genome Res. 12:1611-1618.

Sterky F., Bhalerao R.R., Unneberg P., Segerman B., Nilsson P., Brunner A.M., Charbonnel-campaa L., Lindvall J.J., Tandre K., Strauss S.H., Sundberg B., Gustafsson P., Uhlén M., Balherao R.P., Nilsson O., Ssandberg G., Karlsson J., Lundeberg J., Jansson S. 2004. A Populus EST resource for plant functional genomics. Proc Natl. Acad. Sci. USA 101: 13951-13956.

Stone S.L., Williams L.A., Farmer L.M., Vierstra R.D., Callis J. 2006. KEEP ON GOING, a RING E3 ligase essential for Arabidopsis growth and development, is involved in abscisic acid signaling. Plant Cell 18: 3415-3428.

Ströeker E., Wang X.J.,Roloff N., Klein P., Husemann A., Dietz K.J. 2009. Redox-dependent regulation of the stressinduced zinc-finger protein SAP12 in Arabidopsis thaliana. Mol. Plant 2: 357-367.

Sugiura T., Kuroda H., Honjo H., Ito D. 2002. Temperature dependence of endodormancy development in flower buds of 'Kousui' japanese pear and a model for estimating the completion of endodormancy. Acta Hort. 2 (587):345352.

Sung S., Amasino R. 2004. Vernalization in Arabidopsis thaliana is mediated by the PHD finger protein VIN3. Nature 427:159-164.

Sung S., He Y., Eshoo T.W., Tamada Y., Johnson L., Nakahigashi K., Goto K., Jacobsen S.E. Amasino R.M. 2006. Epigenetic maintenance of the vernalized state in Arabidopsis thaliana requires LIKE HETEROCHROMATIN PROTEIN 1. Nat. Genet. 38:706-710.

Svedsen E., Wilen R., Stevenson R., Liu R., Tanino K.K. 2007. A molecular marker associated with low-temperature induction of dormancy in red osier dogwood (Cornus sericea). Tree Physiol. 27: 385-397.

Swiezewski S., Liu F., Magusin A., Dean C. 2009. Cold-induced silencing by long antisense transcripts of an Arabidopsis Polycomb target. Nature 462: 799-802.

Tacken E., Ireland H., Gunaseelan K., Karunairetnam S., Wang D., Schultz K., Bowen J., Atkinson R.G., Johnston J.W., Putterill J., Hellens R.P., Schaffer R.J. 2010: The role of ethylene and cold temperature in the regulation of the apple POLYGALACTURONASE1 Gene and Fruit Softening. Plant Physiol. 153: 294-305.

Tamura F., Tanabe K., Ikeda T. 1993. Relationship between intensity of bud dormancy and level of ABA in japanese pear 'Nijisseiki'. J. Jpn.Soc. Hort.Sci. 62: 75-81.

Tanaka M., Kikuchi A., Kamada H., 2008. The Arabidopsis histone deacetylates HDA6 and HDA19 contribute to the repression of embryonic properties after germination. Plant Physiol. 146:149-161.

Tanino K.K. 2004. Hormones and endodormancy induction in woody plants. J. of Crop Improvement 10/ in: Adaptations and responses of woody plants to environmental stresses ed. Rajeev Arora Food Product Press, Haworth Press Inc. 157-199.

Tanino K.K., Kalcsits, L., Silim S., Kendall E., Gray G.R. 2010. Temperature-driven plasticity in growth cessation and dormancy development in deciduous woody plants: a working hypothesis suggesting how molecular and cellular function is affected by temperature during dormancy induction. Plant. Mol. Biol. 73: 49-65

Thévenin J., Pollet B., Letarnec B., Saulnier L., Gissot L., Maia-Grondard A., Lapierre C., Jouanin L. 2011. The simultaneous repression of CCR and CAD, two enzymes of the lignin biosynthetic pathway, results in sterility and dwarfism in Arabidopsis thaliana. Mol. Plant 4: 70-82.

Thompson, M.M., D.C. Smith and J.E. Burgess. 1985. Non-dormant mutants in a temperate tree species, Corylus avellana L. Theor. Appl. Genet. 70:687-692.

Topp BL., Sherman W.B., Raseira M.C.B. 2008. Low-chill cultivar development. In: Layne D.R., Bassi D. (eds.) The peach: botany, production and uses. Wallingford, Oxfordshire, UK; CABI pp: 106-138.

Toth R., Kevei E., Hall A., Millar A.J., Nagy F., Kozma-Bognar L. 1991. Circadian-clock regulated expression of phytochrome and cryptochrome genes in Arabidopsis. Plant Physiol. 127: 1607-1616. 
Trevaskis B., Bagnall D.J., Ellis M.H., Peacock W.J., Dennis E.S.2003. MADS-box genes control vernalization-induced flowering in cereals. Proc. Natl. Acad. Sci. USA 100: 13099-13104.

Trevaskis B., Hemming M.N., Dennis E.S., Peacock W.J. 2007b. The molecular basis of vernalization-induced in flowering in cereals. Trends Plant Sci. 12: 352-357.

Trewavas A.J., Jones H.G.1991. An assessment of the role of ABA in plant development. In; Davies W.J., Jones H.G. (Eds.) Abscisic acid: physiology and Biochemistry. BIOS Scientific Publishers, Oxford pp 169-188.

Tzonev R., Erez A. 2003. Inheritance of chilling requirement for dormancy completion in apricot vegetative buds. Acta Hort. 622:429-436.

Valentini N., Me G., Ferrero R., Spanna F. 2001. use of bioclimatic indexes to characterize phenological phases of apple varieties in Northern Italy. Int. J. Biometereol. 45:191-195.

Vegis A. 1964. Dormancy in higher plants. Annu. Rev. Plant Physiol. 15: 185-224.

Verde I., Quarta R., Cedrola C., Dettori M.T. 2002. QTL analysis of agronomic traits in a BC1 peach population. Acta Hort. 592:291-297.

Viti R., Monteleone P. 1991. Observations on flower bud growth in some low yield varieties of apricot. Acta Hort. 293: 319-326.

Viti R., Monteleone P. 1995. High temperature influence on the presence of flower bud anomalies in two apricot varieties characterized by different productivity. Acta Hort. 384: 283-289.

Viti R., Andreini L., Ruiz D., Egea J., Bartolini S., Iacona C., Campoy J.A. 2010. Effect of climatic conditions on the overcoming of dormancy in apricot flower buds in two Mediterrenean areas: Murcia (Spain) and Tuscany (Italy). Sci. Hortic. 124: 217-224.

Walton E.F., Wu R.M., Richardson A.C., Davy M., Hellens R.P., Thodey K., Janssen B.J., Gleave A.P., Rae G.M., Wood M., Schaffer R.J. 2009. A rapid transcriptional activation is induced by the dormancy-breaking chemical hydrogen cyanamide in kiwifruit (Actinidia deliciosa) buds. J. Exp. Bot. 60 (13): 3935-3848.

Wareing P.F. 1956. Photoperiodism in woody plants. Annu. Rev. Plant Physiol. 7, 191-214.

Wei H., Dhanaraj A.L., Rowland L.J:, Fu Y., Krebs S.L., Arora R. 2005. Comparative analysis of expressed sequence tags from cold-acclimated and non-acclimated leaves of Rhododedron catawbiense Michx. Planta 221: 406-416.

Weigel D., Nilsson O. 1995. A developmental switch sufficient for flower initiation in diverse plants. Nature 377: 495500.

Weinberger J.H. 1950. Chilling requirements iof peach varieties. Proc. Am. Soc. Hort. Sci. 56: 122-128.

Weiser C.J. 1970. Cold resistance and injury in woody plants. Science 169: 1269-1278.

Weldon G.P. 1934. Fifteen years study of delayed foliation of deciduous fruit trees in southern California. Calif. Agric. Bull. 23: 160-181.

Welling A., Kaikuranta P., Rinne P. 1997. Photoperiodic induction of dormancy and freezing tolerace in Betula pubescens. Involvement of ABA and dehydrins. Physiol. Plant. 100: 119-125.

Welling A., Rinne P., Vihera-Aarnio A., Kontunen-Soppela S., Heino P., Palva E.T. 2004. Photoperiod and temperature differentially regulate the expression of two dehydrin genes during overwintering of birch (Betula pubescens Ehrh.). J. Exp. Bot. 55: 507-516

Went F.W. 1948. Thermoperiodicity. In: Verdoon F. (ed.) Vernalization and photoperiodism- a symposium. Chronica Botanica Co. Waltham MA, USA.

Went F:W. 1953. The effect of temperature on plant growth. Ann. Rev. Plant Phys. 4: 347-362.

Wisniewski M., Bassett C, Arora R. 2004. Distribution and partial characterization of seasonally expressed proteins in different aged shoots and roots of 'Loring' peach (Prunus persica). Tree Physiol. 24 (3): 339-345.

Wisniewski M., Norelli J., Basset C., Artlip T., Macarisin D. 2011. Ectopic expression of a novel peach (Prunus persica) CBF transcription factor in apple (Malus $x$ domestica) results in short-day induced dormancy and increased cold hardiness. Planta 233: 971-983.

Wisniewski M., Webb R., Balsamo R., Close T.J., Yu X.M., Griffith M. 1999. Purification, immunolocalization, cryoprotective, and antifreeze activity of PCA60: a dehydrin from peach (Prunus persica). Physiol. Plant 105: 600-608.

Xin H., Guo-sheng Z., Si-lan D., Shu-peng G. 2008. Identification of differentially expressed genes associated with bud dormancy release in tree peony (Peonia suffruticosa) by suppression subtractive hybridization. For. Stud. China 10: 88-94.

Xu, X., Van Lammeren A. A. M., Vermeer E., Vreugdenhil D. 1998. The role of gibberellin, abscisic acid, and sucrose in the regulation of potato tuber formation in vitro. Plant Physiol. 117, 575-584

Xue G.P. 2002. Characterisation of the DNA-binding profile of barley HvCBF1 using an enzymatic method for rapid, quantitative and high-throughput analysis of the DNA-binding activity. Nucleic Acids Res 30: e77.

Yamane H., Kashiwa Y., Ooka T., Tao R., Yonemori K. 2008. Suppression subtractive hybridization and differential screening reveals endodormancy-associated expression of an SVP/AGL24-type MADS box gene in lateral vegetative buds of Japanese apricot. J. Am. Soc. Hort. Sci. 133: 708-716. 
Yamane H., Ooka T., Jotatsu H., Hosaka Y., Sasaki R., Tao R. 2011. Expressional regulation of PpDAM5 and PpDAM6, peach (Prunus persica) dormancy-associated MADS-box genes, by low temperature and dormancybreaking reagent treatment. J. of Exp. Bot. 62: 3481-3488.

Yan L., Loukoianov A., Tranquilli G., Helguera M., Fahima T., Dubcovsky J., 2003. Positional cloning of the wheat vernalization gene VRN1. Proc. Natl. Acad. Sci. USA 100: 6263-6268.

Yan L., Loukoianov A., Blechi A. Tranquilli G., Ramakrishna W., SanMiguel P., Bennetzen J.L., Echenique V., Dubcovsky J. 2004. The wheat VRN2 gene is a flowering repressor down-regulated by vernalization. Science 303: $1640-1644$.

Yang S.H., Loopstra C.A. 2005. Seasonal variation in gene expression for loblolly pines (Pinus taeda) from different geographical regions. Tree Physiol 25: 1063-1073.

Yooyongwech S., Horigane A.K., Yoshida M., Yamaguchi M., Sekozawa Y., Sugaya S., Gemma H. 2008. Changes in aquaporin and magnetic resonance imaging of water status in peach tree flower buds during dormancy. Physiol. Plant 134: 522-533.

Yooyongwech S., Sugaya S., Sekozawa Y., Gemma H. 2009. Differential adaptation of high- and low-chill dormant peaches in winter through aquaporin gene expression and soluble sugar content. Plant Cell Rep. 28, 1709-1715.

Yoshida S. 1984. Chemical and biophysical changes in the plasma membrane during cold acclimation of muldberry bark cells (Morus bombycis Koidz. Cv Goroji). Plant Physiol. 76: 257-265.

Zhang C.K., Lang P., Dane F., Ebel R.C., Singh N.K., Locy R.D., Dozier W.A. 2005 Cold acclimation induced genes of trifoliate orange (Poncirus trifoliata). Plant Cell Rep. 23: 764-769. 
